Portland State University

PDXScholar

Dissertations and Theses

Dissertations and Theses

Spring 1-1-2012

\title{
Motivation in the Portland Chinuk Wawa Language Community
}

Abigail Elaina Pecore

Portland State University

Follow this and additional works at: https://pdxscholar.library.pdx.edu/open_access_etds

Part of the Bilingual, Multilingual, and Multicultural Education Commons, Indigenous Studies Commons, and the International and Intercultural Communication Commons Let us know how access to this document benefits you.

\section{Recommended Citation}

Pecore, Abigail Elaina, "Motivation in the Portland Chinuk Wawa Language Community" (2012). Dissertations and Theses. Paper 806.

https://doi.org/10.15760/etd.806

This Thesis is brought to you for free and open access. It has been accepted for inclusion in Dissertations and Theses by an authorized administrator of PDXScholar. Please contact us if we can make this document more accessible: pdxscholar@pdx.edu. 
Motivation in the Portland Chinuk Wawa language community

by

Abigail Elaina Pecore

A thesis is submitted in partial fulfillment of the requirements for the degree of

\author{
Master of Arts \\ in \\ Teaching English to Speakers of Other Languages
}

Thesis Committee:

Nariyo Kono, Chair

Keith Walters

Kimberley Brown

Portland State University

(c)2012 


\begin{abstract}
Throughout the world, languages are becoming extinct at an alarming rate. Perhaps half of the 6,000-7,000 languages worldwide will go extinct in the next 50-100 years. One of these dying languages, Chinook Jargon or Chinuk Wawa, a language found in the Pacific Northwest of the United States, is in the process of being revitalized through the concerted efforts of the Confederated Tribes of Grand Ronde (CTGR). Reasons to revitalize endangered languages often seem irrelevant to our modern daily lives, and revitalizing these languages is a difficult process requiring much dedication, commitment, and persistence.

In light of this significant struggle, understanding people's motivations could contribute to a better understanding of how to involve more people in language revitalization. Ideally, such an understanding would contribute to strengthening a community's efforts to revitalize their language.

This exploratory, ethnographic case study explores the motivations of eight participants in the Portland Chinuk Wawa language community involved in revitalizing Chinuk Wawa over a nine-month period in 2011.

The results of the study showed that seven major themes of motivation were prevalent for the participants: connections made through Chinuk Wawa, preservation of Chinuk Wawa, relationships, instrumental motivation, affective motivation, identity motivation, and demotivation.
\end{abstract}




\section{ACKNOWLEDGMENTS}

I would like to thank the Portland Chinuk Wawa language community who welcomed me and many others with generosity and warmth.

This study is the result of many people's support and encouragement. I am grateful to all of the participants, who willingly shared their experiences of learning and speaking Chinuk Wawa. I thank the Grand Ronde community for their permission to conduct this study and their enthusiasm regarding this project. Finally, I am grateful for my thesis chair, Nariyo Kono, for her continued patience and insight into this research.

On a more personal note, I am grateful for the collegial support of both Marianne Kastner and Ariana Chandler while I was writing this thesis. I am deeply indebted to Vivianne Tallman for her editing skills and her continued belief in me and this project. Finally, thank you to all of my friends and family who supported me throughout this process with so much support, faith, and love. 


\section{TABLE OF CONTENTS}

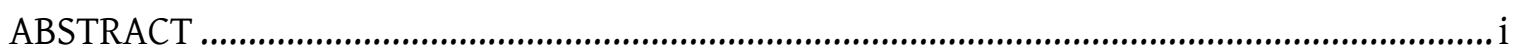

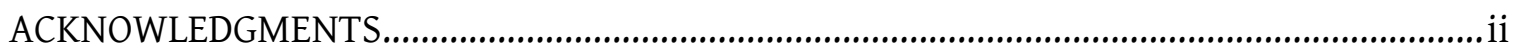

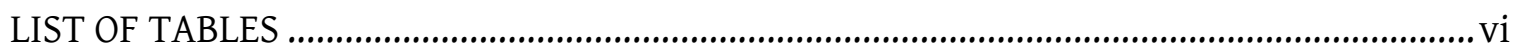

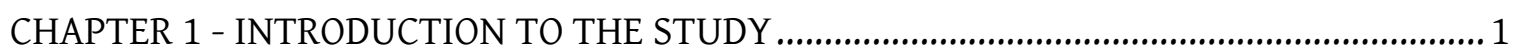

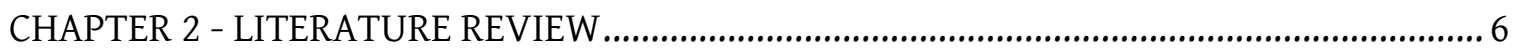

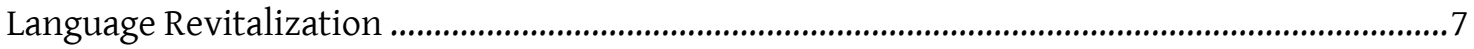

Language endangerment and language revitalization.................................................................

The phenomenon of language death. ..................................................................................

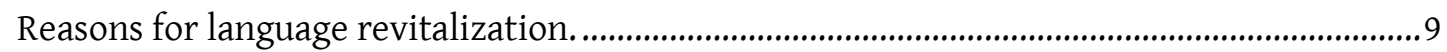

Current trends in language revitalization. ..........................................................................

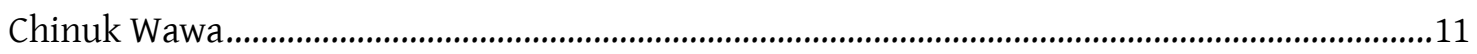

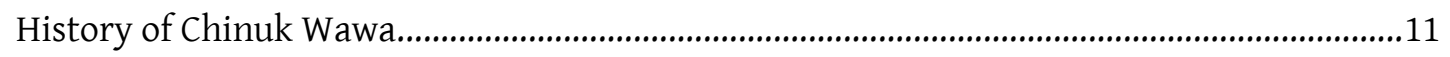

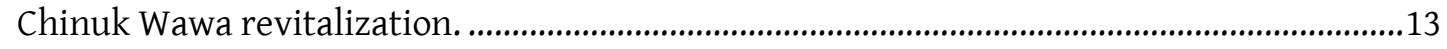

Existing research and documentation on Chinuk Wawa............................................................14

Current Chinuk Wawa language programs. ............................................................................... 14

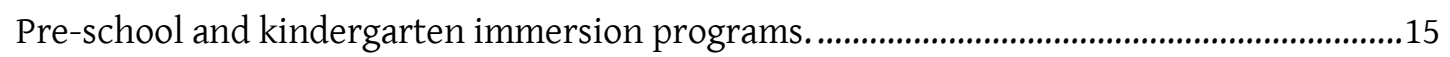

Lane Community College adult classes (credit/non-credit)......................................................16

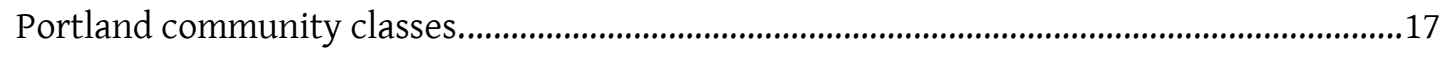

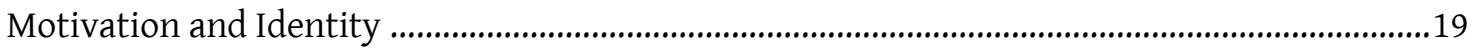

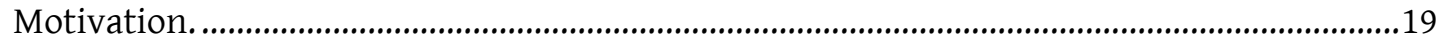

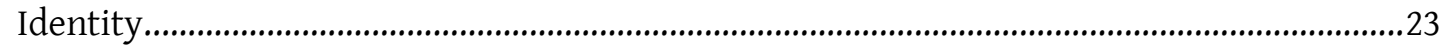

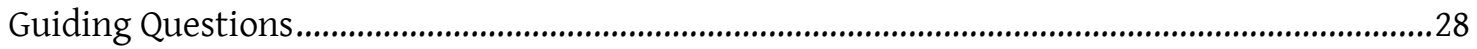

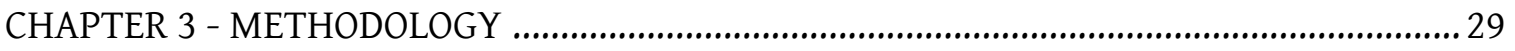

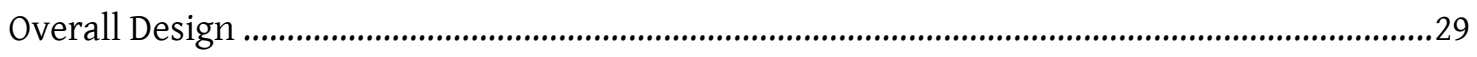

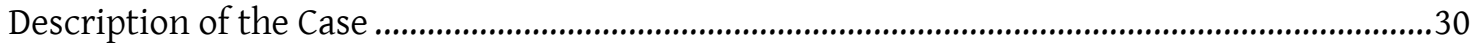

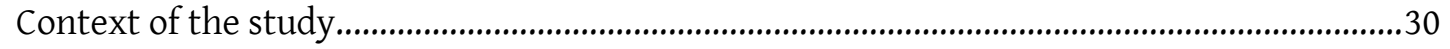

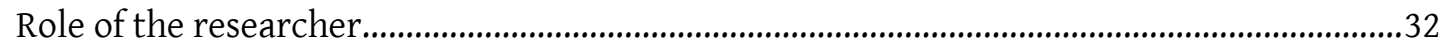

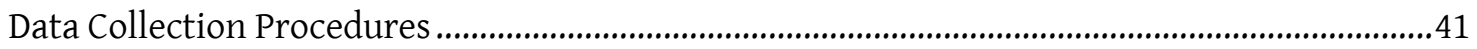

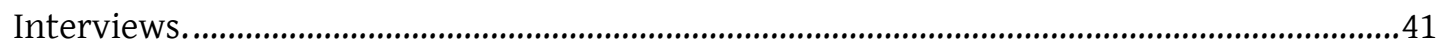




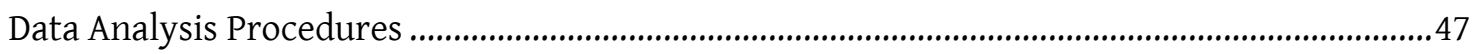

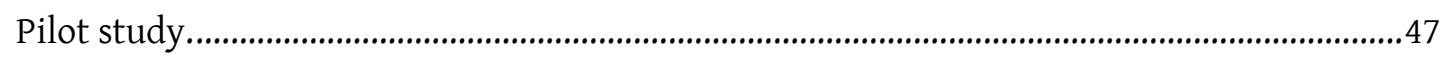

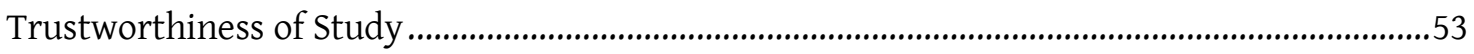

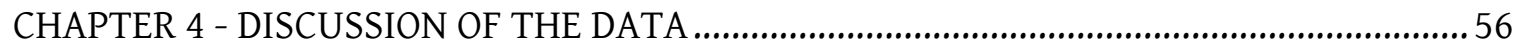

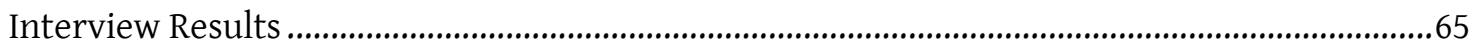

Theme 1: Connection to Pacific Northwest Native culture, the Pacific

Northwest region, and to participants' spirituality. .................................................................6

Theme 2: Preservation, maintenance and revitalization of historical

knowledge/Chinuk Wawa/Pacific Northwest Native culture. ..................................................83

Theme 3: Relationships between people/people belonging to a community..........................95

Theme 4: Instrumental motivation - learning Chinuk Wawa as a means to

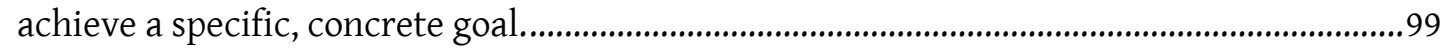

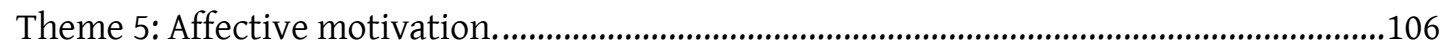

Theme 6: Self-ascribed identity as a member of the Chinuk Wawa language

community.

Theme 7: Demotivation - reasons for not continuing to learn or teach

Chinuk Wawa, or reasons that it was difficult to continue. .....................................................120

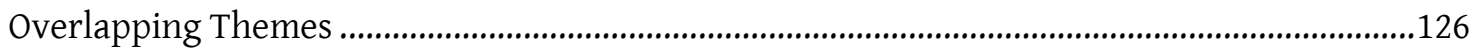

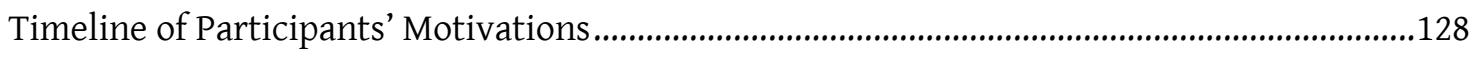

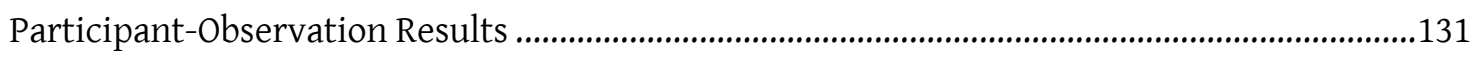

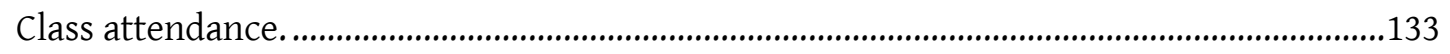

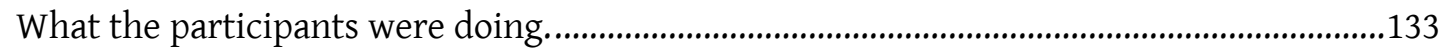

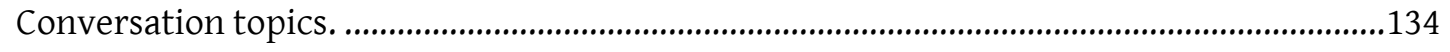

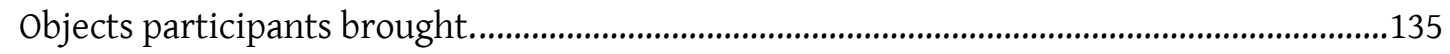

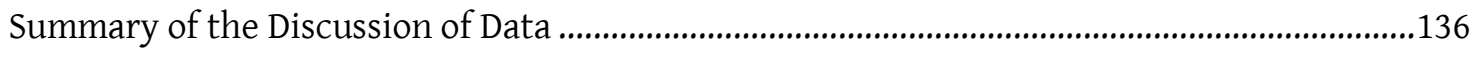

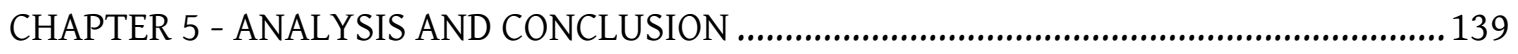

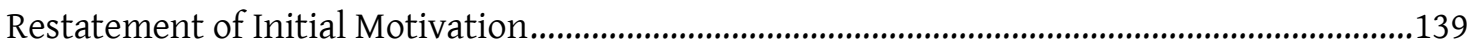

Restatement and Answers to the Guiding Questions ..................................................................140

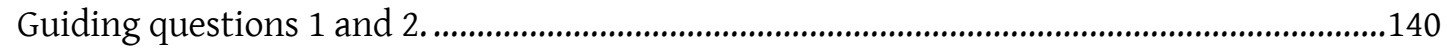

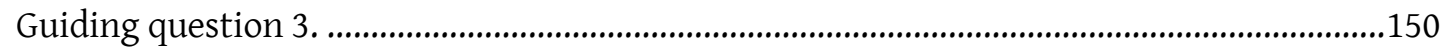

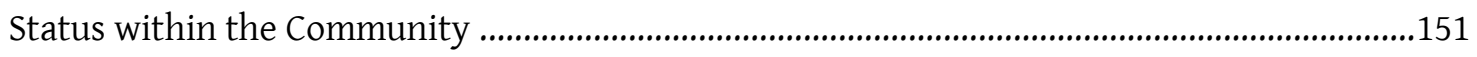

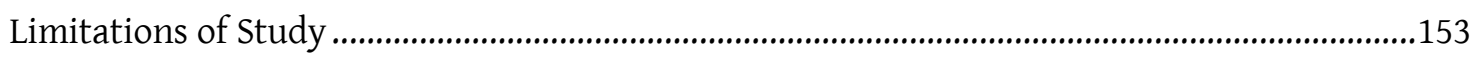




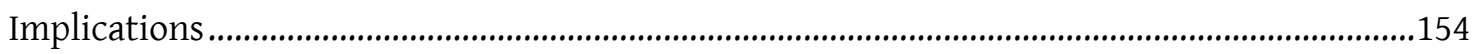

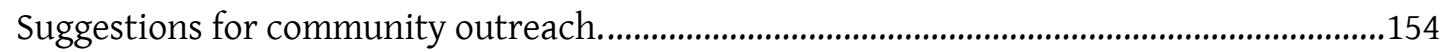

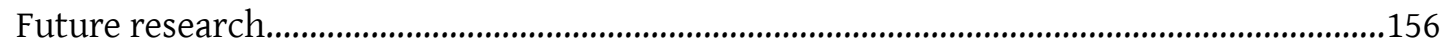

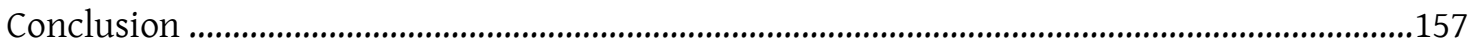

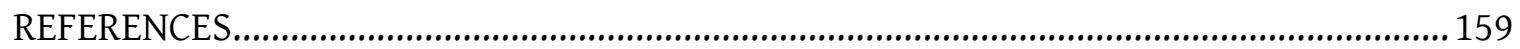

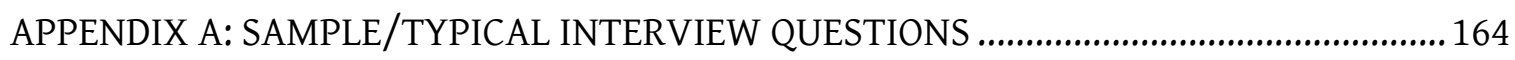

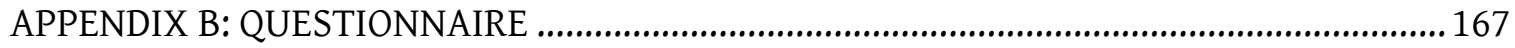

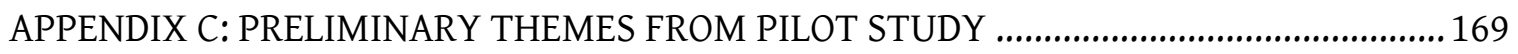




\section{LIST OF TABLES}

Table 1: Summary of Portland Chinuk Wawa Classes 2007-2011........................................31

Table 2: Summary of themes mentioned by participants..................................................58

Table 3: Themes, categories, and sub-categories showing participants' motivations for

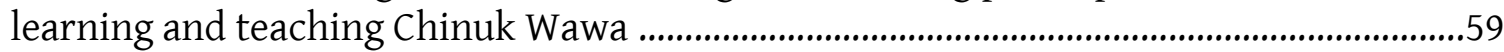

Table 4: List of participants' pseudonyms and length of involvement in the Portland Chinuk Wawa language community as of spring 2011.........................................................64

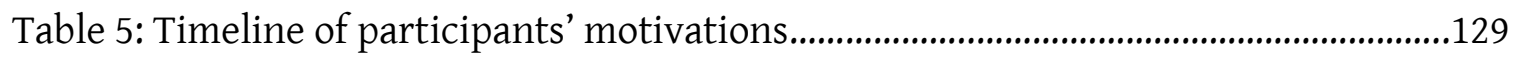




\section{CHAPTER 1}

\section{INTRODUCTION TO THE STUDY}

This thesis is an instrumental case study of motivation in the Portland Chinuk Wawa language community. I study one issue, motivation, in a bounded case, the Portland Chinuk Wawa classes offered through the Confederated Tribes of Grande Ronde, the Northwest Indian Languages Institute, and Lane Community College. The research framework is a qualitative, exploratory, ethnographic case study.

The following is a description of a typical experience in one of the Portland Chinuk Wawa classes: It is April $25^{\text {th }}, 2012$. I walk into a Chinuk Wawa ${ }^{1}$ class and join a group of seven people sitting at a round table in a kitchen. Some people I know really well, and others I have never met. The group welcomes me to the class with greetings and smiles. There are snacks on the table for the students to eat while learning Chinuk Wawa. There is one small rock in front of each student. The teacher directs the activities, mostly in Chinuk Wawa, occasionally using sign language. He asks a simple question of a seasoned student next to him in Chinuk Wawa, ikta ukuk? [Translation: What is this?] and simultaneously gestures in sign language to the stone. The student responds, stun ukuk [translation: This is a stone.] This same dialog is repeated around the table. Regularly-attending students use sign language corresponding to what is being said. Some people in the class can speak Chinuk Wawa fluently; others had never

\footnotetext{
${ }^{1}$ I refer to the language as Chinuk Wawa. Other typical labels include: chinuk wawa, Chinook Jargon, and
} Chinook. 
heard it before. By the end of this lesson, new students have spoken Chinuk Wawa in simple full sentences. In the adjacent office and classroom, two people are also working. One person is teaching a satellite Chinuk Wawa class through a distance learning television monitor connected to a class in Eugene, Oregon. The other person works at a computer in a small office filled with Chinuk Wawa archives and craft materials. Children's art and framed pictures of Native Americans ${ }^{2}$ cover the walls in the classroom. A case filled with traditional Northwest Native American crafts sits against one wall. A bulletin board announces current events and community. This is a typical Wednesday night of Chinuk Wawa classes at the Confederated Tribes of Grand Ronde (CTGR) Portland tribal office.

When I began studying Chinuk Wawa in 2008, I was compelled by the language and the content we were learning and also fascinated by my classmates. Why were my classmates and teachers working so passionately to learn and teach Chinuk Wawa? Did they have tribal or ethnic connections to the language? Were they history or possibly primitive skills buffs? There were an interesting mix of people at the classes, people of different ages, different socioeconomic classes, different educational backgrounds, and greatly differing life experiences. I wondered what drew this diverse group of people to Chinuk Wawa classes.

\footnotetext{
${ }^{2}$ I use the terms "Indian," "Native American," and "Native" interchangeably. In doing so, I am referring to ethnicity rather than the mother tongue of that participant.
} 
After being involved in classes for two years, I decided to conduct a study about motivation in this community that would fulfill my graduation requirements for an MA in TESOL. The participants of this study are the students and teachers in the Portland Chinuk Wawa language community. When I use the term 'community,' I am referring to the group of people who show up regularly to Wednesday night classes and have a deep commitment to Chinuk Wawa language evidenced by their involvement. At one counting, there were about 30 semi-fluent to fluent speakers. Semi-fluency was determined as meeting ACTFL Proficiency Guidelines of speakers at the Intermediate Mid sublevel (http://www.actfl.org/files/public/ACTFLProficiencyGuidelines2012_FINAL.pdf). I chose to interview both teachers and students because there were not enough committed people to interview in just one of those categories. Additionally, in a few cases, participants acted as both students and teachers depending on the class context. I selected the participants based on their willingness and ability to do an interview with me and their willingness to allow me to use the results for this study. Therefore, the participant sample was a convenience sample. I interviewed eight people who had been studying Chinuk Wawa for a minimum of six months in the classes offered through the Confederated Tribes of Grand Ronde in Portland, Oregon.

In studying the Portland Chinuk Wawa language community, I chose to focus on one issue, motivation. I wanted to know why Chinuk Wawa students were motivated to begin and continue learning Chinuk Wawa. I chose one of Williams' (1994) two definitions of motivation, "reasons for wanting to do something," as the guiding 
definition for my study. In this thesis, this definition translates into reasons that participants want to begin and continue to study Chinuk Wawa.

Many studies in second language acquisition research the connection between motivation and achievement. However, I saw that certain Chinuk Wawa students were motivated to begin and continue coming to class whether they picked up the language slowly or quickly. I was interested in understanding what motivated students and teachers of Chinuk Wawa in this community, regardless of their proficiency in the language.

In fall of 2009, in preparing to do this Master's thesis, I conducted a pilot study which involved interviewing two Chinuk Wawa students. During the interviews, both students mentioned several motivations for studying Chinuk Wawa. One particularly interesting and pervasive theme of motivation was identity. In coding the pilot studies, I included several aspects of identity: personal, ethnic, social, cultural, and extended it to include values and personal beliefs about language. Most of the codes were implicit references to identity. One student, for example, said that she had a Cherokee ancestor and, although the language was not passed down to her, she felt some connection. I coded the original quote as evidence of ethnic identity as motivating her since she was answering the question about her reasons for wanting to study Chinuk Wawa. Additionally, I included all mentions of family and friends that related to Chinuk Wawa. However, for the current study, I needed to delineate the notion of identity more clearly in order to show how students were motivated to study Chinuk Wawa because of aspects of their identities. 
For this study, I use part of Norton's (2000, p. 5) definition of identity: “how a person understands his or her relationship to the world." Additionally, I use Bucholtz and Hall's definition of identity as "the social positioning of self and other" (2005, p. 586). I looked for cases where participants talked about aspects of their identity as motivating them to study Chinuk Wawa. In coding the interview transcripts, I adopted Bucuras' (2004, p. 70) theme title of "self-ascribed identity," and I only included explicit or obvious implicit references to participants' identities as it related to Chinuk Wawa.

Throughout this research I reference the following institutions and tribe:

- Confederated Tribes of Grand Ronde (CTGR)

- Lane Community College (LCC)

- Northwest Indian Language Institute (NILI)

In order to provide the necessary information to understand this study, Chapter Two includes a literature review of language revitalization, a brief history and overview of Chinuk Wawa, and a literature review of motivation and identity. Chapter Two concludes with the guiding questions for this study. Chapter Three provides a detailed description of the methodology, the role of the researcher, and a description of the pilot study that preceded this study. In Chapter Four, I present the seven themes of motivation and describe the case in more detail. In Chapter Five, I further analyze two of the themes and respond to the guiding questions of this study. 


\section{CHAPTER 2}

\section{LITERATURE REVIEW}

This literature review includes discussions about language revitalization, the history and revitalization of Chinuk Wawa, motivation, and identity. Since this study considers people's motivations to learn and teach a specific language, Chinuk Wawa, the first section of the literature review provides information about the wider context of language revitalization, and, thus, situates Chinuk Wawa revitalization as part of a larger phenomenon and not simply an isolated case.

In the second section, I address Chinuk Wawa as a Pacific Northwest contact language and describe the historical and contemporary context of the community under study. The section includes a brief overview of its history, current revitalization efforts of Chinuk Wawa by the Confederated Tribes of Grand Ronde (CTGR), existing research and documentation of the language, and finally, a description of the classes where Chinuk Wawa is currently being taught. This full description is necessary in order to gain an understanding of this unique case and its history in order to adequately understand the motivations of the participants.

In the third section, I provide an overview of research on motivation and identity as it relates to second language. I then examine Dörnyei's work (2009) in detail, because it looks at identity as it relates to motivation. Additionally, I delineate the definitions that I use to understand the concepts of motivation and identity as they relate to this study. As the following literature review reveals, researchers have not combined these particular topics in the way that this study does. Research has not 
looked at the issue of motivation in a small, urban, tribally-funded language revitalization community. This particular approach is useful because it provides a snapshot of a pocket of language learners and teachers engaged in a unique pursuit: that of revitalization of a hybrid contact language.

\section{Language Revitalization}

\section{Language endangerment and language revitalization.}

In the next 50-100 years, it is likely that over half of the estimated 6,000 to 7,000 languages spoken around the world will cease to exist (Grenoble \& Whaley, 2006, p. 1). During the period before European contact in what is now the United States and Canada, 300-500 different languages were spoken. Of those, 200 languages survive today. However, according to Krauss, a linguist from the University of Alaska Fairbanks who is working to encourage the documentation of endangered languages, only 34 of those 200 languages are being learned by children (as cited in McCarty, Romero, and Zepeda, 2006, p.2). Thus, $83 \%$ of remaining indigenous languages in the US and Canada are moribund, meaning that children are not learning the native or indigenous language of their parents. Language revitalization is the effort to keep these endangered languages alive.

\section{The phenomenon of language death.}

Non-dominant, heritage, and minority languages frequently become endangered or extinct within immigrant communities. Larger social, political, or economic trends often negatively affect the vitality of these languages. Generally, a minority language is not the language of the economy or upward social mobility, and 
typically parents wish their children to be financially successful. Thus, children often choose or are encouraged to learn economically powerful languages such as English, Arabic, Russian, or Spanish, rather than to speak a minority or non-dominant language. In the US, heritage languages are being spoken less and less by immigrants to the U.S. as they shift to speaking English instead. Cummins (2005) stated that "according to the 1990 census, some 97\% of the American population knows English 'very well' or 'well”' (p. 21). Second generation immigrants commonly learn and use English more than their heritage language (Cummins, 2005; Hinton, 1999).

The languages of Native American communities have long been subjected to pressures toward language shift. Historically, the United States government, and other agencies identified with that government, actively worked to ensure that Native American communities stopped speaking their mother tongues. For example, during the late $19^{\text {th }}$ century and much of the $20^{\text {th }}$ century, Native American children in the United States were commonly forced to leave their home communities to attend boarding schools. There, these Native children were taught English and discouraged or prevented from using their native languages. In these boarding schools during the $19^{\text {th }}$ and $20^{\text {th }}$ centuries, children were physically punished for speaking in a native language. Intentional political forces exerted on Native American communities resulted in many Native North American languages becoming extinct.

A crucial difference exists between Native American languages, on the one hand, and minority and heritage languages of immigrant groups, on the other. When all of a group of immigrants stop speaking their heritage language, that heritage language 
almost always continues to be actively spoken in the mother country. However, when there are no remaining speakers of a Native American language, that language ceases to exist as a spoken language. In effect, it becomes extinct.

\section{Reasons for language revitalization.}

Grenoble and Whaley provide a list of common reasons for language revitalization:

Linguistic diversity is important to scientific inquiry, languages are irreplaceable cultural treasures more valuable than any material artifacts, each language encodes a unique worldview, and languages spoken by minority groups have an integral role in protecting and expanding minority rights. As this list reveals, reasons to revitalize a language are diverse and often political as well as cultural. (2006, p. 20)

In writing about the tribal language programs in Warm Springs, Klamath, and Grand Ronde, Haynes (2004, p. 89) stated that her interviewees "view these language programs as central to cultural continuation, and to strengthening their tribes' sense of identity and community."

Each Native community who has sought to revitalize a Native language has its own reasons for doing so. In many communities, a key person spearheads the language revitalization effort, and typically there are a range of opinions within the community about these efforts. 


\section{Current trends in language revitalization.}

In the past 50 years, innovative programs to revitalize languages have been appearing worldwide with the goal of reversing the trends that lead to language death (Grenoble \& Whaley, 2006). With the creation of language revitalization programs, many communities and people are working to teach endangered languages in a variety of ways, some examples being total-immersion programs, teaching the local language as a second "foreign" language, community-based programs, and masterapprenticeship programs.

The shift began with the Civil Rights Movement of the 1960's, which made way for an era of increased tolerance towards social differences in many segments of society including multilingual groups and speakers of non-dominant languages. In the past 35 years, many Native American communities have realized that their tribal languages were spoken in fewer and fewer domains (i.e. particular social spaces where a language is used, such as for religious ceremonies, in the home, or for government proceedings), and some are now working to reverse that trend. One example of this is with the Hualapai language, the Native American language spoken by the Hualapai and Havasupai peoples of northwestern Arizona. In 1975, the only certified Hualapai teacher was appointed as Director of the first Hualapai Bilingual and Bicultural Education program, which has subsequently served as a model for other community revitalization efforts (Hale et al., 1992). More recently, the Native American Languages Acts of 1990 and 1992 were signed by President Bush with the goal of "assuring the survival and continuing vitality of Native American languages" (Hinton, 1996, p. 187). 


\section{Chinuk Wawa}

Chinuk Wawa was a language historically spoken in the Pacific Northwest as a contact language, a modified language that "comes about through contact between two

or more previously existing languages" (Sebba, 1997, p. 2). A contact language generally emerges when people speaking mutually unintelligible languages come in contact through trade or colonization and need to communicate. Grammatical features and lexical items of contact languages are comprised from the contributing languages. In the case of Chinuk Wawa, several languages were the primary languages contributing to its lexicon and grammar: Lower Chinook, Lower Chehalis, Nu-chal-nuth (Nootkan), English, and French.

The origins of Chinuk Wawa are mysterious as it is uncertain as to whether Chinuk Wawa was spoken in some form before European descendants arrived on the West coast or formed because of the contact between Europeans and Native Americans. This study will not delve into the intricacies of this debate; for more information on this debate, see Lang (2008) and Silverstein (1996).

\section{History of Chinuk Wawa.}

In the latter part of the $18^{\text {th }}$ century, British and American trading ships began to arrive on the coast of the Pacific Northwest (Lang, 2008). Many languages were spoken in this area, Nootka, Nisqually, Chinook, and Chehalis, to name a few. These languages were difficult for the newcomers to learn because of sounds drastically different from those in languages familiar to them and their complex grammatical structure. Because of the limited geographical range of each language, it was not efficient for traders to learn 
them all. Chinuk Wawa, with its fairly simple and flexible grammar, filled the need for communication both between Native Americans without a common language and between Native Americans and traders. According to Boas (1892), Chinuk Wawa had been spoken throughout the Pacific Northwest at least since the time British traders came to the Pacific coast in the 1770's.

In the mid- $19^{\text {th }}$ century, the US government forced many tribes onto reservations. On the Grand Ronde Reservation, formed in 1856, there were at least eight distinct Native American languages spoken by small groups of Indians. However, most if not all people also spoke Chinuk Wawa, and, thus, Chinuk Wawa became the first common language of the inhabitants of the Grand Ronde Reservation. Chinuk Wawa was first creolized at Fort Vancouver (Lang, 2008), and thus, Indians arriving at the Grand Ronde reservation in 1856 may have already spoken a creolized version of Chinuk Wawa. On the reservation, Chinuk Wawa was further creolized during the period from the formation of the reservation and into the late 1800's when English began to compete with it as the common language.

Generally, a creole language emerges when the first-generation of pidgin speakers learn the parents' pidgin as their first language (Larsen-Freeman \& Long, 1991, p. 257). According to Zenk (1984), "by the fact of such an adoption, Chinuk Jargon was a "creole language' at Grand Ronde, in a somewhat restricted or special sense-a language of primary use in community and family, yet hardly anyone's only such language" (p. iv). It was used in households as well as in the community. By the late 1800's, many of the Native American languages represented on the reservation were no longer widely 
spoken, and first Chinuk Wawa, then English, became the primary language there (Zenk, 1988).

\section{Chinuk Wawa revitalization.}

In the 1990's, the Confederated Tribes of Grand Ronde (CTGR) decided to focus on revitalizing Chinuk Wawa and teach the CTGR this language with the hope that it be spoken again. Reasons for deciding to revitalize Chinuk Wawa are stated on the CTGR website (http://www.grandronde.org/ikanum/index.html):

Before there was a reservation at Grand Ronde, there was a language held in common by many of our ancestors. This language is Chinuk Wawa, a hybrid indigenous language with words from local tribal languages as well as English and French. At Grand Ronde, it became the first language of many families on the early reservation. We feel that preserving the original common language of our community is an important aspect of preserving our identity. (Ntsayka Ikanum, Our Language section, initial screen) Contemporary language planners at CTGR chose Chinuk Wawa from the many languages originally spoken on the Grand Ronde reservation because it was the last Indian language historically spoken on the reservation. The first generation born on the reservation spoke both their parents' tribal languages as well as Chinuk Wawa. However, the second generation of children born on the reservation spoke Chinuk Wawa and English as their primary languages rather than the tribal languages (Zenk, 1984). Choosing Chinuk Wawa permitted CTGR to avoid favoring the native language of 
any single group while permitting them to support and revitalize a Native language spoken by all those living in the reservation in the recent past.

\section{Existing research and documentation on Chinuk Wawa.}

According to Sebba (1997, p. 28) "Chinuk Wawa is a well-documented language," meaning there are existing word lists dating to the earliest tribal contact with Europeans in the early 1800 's. Several grammars and dictionaries have been compiled (e.g. Gibbs, 1863; Gill, 1909; Hale, 1890; Shaw, 1909; Thomas, 1970). However, these publications are all written by non-Native speakers, making these publications strongly associated with non-Indian pronunciation and usage. The Confederated Tribes of Grand Ronde is spearheading the contemporary revitalization of Chinuk Wawa. The consulting linguist, Henry Zenk, has compiled two dictionary databases of the Chinuk Wawa historically spoken as the common language at Grand Ronde and elsewhere on the lower Columbia River: one, documenting the language as used by older generations of Indians, has been published (Chinuk Wawa Dictionary Project 2012); the other, meant for tribal classroom use, includes modern coinages covering new technologies and lifestyles (Chinuk Wawa Dictionary Project 2011).

\section{Current Chinuk Wawa language programs.}

There are several CTGR-affiliated Chinuk Wawa language programs currently in existence: the immersion pre-school and kindergarten in Grand Ronde; adult college level classes taught through Lane Community College in Eugene with distance learning sites in Portland and Grand Ronde; and community classes taught at the CTGR offices in Portland, Eugene, and Grand Ronde. I describe the classes and teaching methods used 
in each program. First, I discuss the pre-school and kindergarten immersion programs at Grand Ronde. Next, I discuss the Lane Community College classes. Finally, I discuss the Portland community classes.

\section{Pre-school and kindergarten immersion programs.}

Presently, at Grand Ronde, children in the pre-school and kindergarten Chinuk Wawa immersion programs are encouraged to speak in Chinuk Wawa as much as possible. The program is based on a model of language immersion developed in New Zealand for the Maori language called Te Kōhanga Reo or the language nest model (Grenoble \& Whaley, 2006, p. 52). It is a programmatic approach to second language learning in which the regular school curriculum is taught completely or mostly in the target language. The target language is the medium of instruction rather than the focus in instruction (Twenge-Jinings, 2006, p. 4). At the Immersion Program in Grand Ronde, the first language of teachers and students is English, and they have varying levels of proficiency in Chinuk Wawa. Ideally, only Chinuk Wawa is spoken in the preschool and kindergarten. There is one class for the pre-school with nine students currently enrolled, and one class for the kindergarten with seven students enrolled (H. Zenk, personal communication, May 14, 2012). The classes are taught by the tribe under an MOU (Memorandum of Understanding) with the local school district. While participation is not restricted to tribal members, tribal members are given first preference (H. Zenk, personal communication, May 21, 2012).

In three one-hour-long observations of this class, I observed students learning numbers, colors, months, days, songs, and games, all in Chinuk Wawa. The classroom 
differed from a conventional U.S. classroom in that there were many Native American cultural objects in the room, like drums, baskets made from local plant materials, and a beaver hide. These were all labeled with Chinuk Wawa words. There were books in both Chinuk Wawa and English and pictures of Grand Ronde tribal elders on the wall. Advantages of this method of language revitalization are that children can learn correct pronunciation easily since they have not passed the critical learning period (Gass \& Selinker, 2001) before the ability to learn a language with native pronunciation is generally lost.

Disadvantages are that it can be difficult to speak Chinuk Wawa when everyone's first language is English. When I observed this class, I noticed that teachers

and students often switched to speaking English when they could not think of the word or expression in Chinuk Wawa or when they dealt with an urgent situation like behavior issues with students.

\section{Lane Community College adult classes (credit/non-credit).}

From fall term 2008 to the present, Lane Community College (LCC) has offered college-level Chinuk Wawa classes in Eugene and, through a distance learning program, satellite classrooms in Portland and earlier, in Salem and Grand Ronde. (This program is henceforth referred to as the LCC distance-learning class). The curriculum for this class was developed by the Confederated Tribes of Grand Ronde (CTGR) and Northwest Indian Language Institute (NILI), an organization affiliated with the University of Oregon and dedicated to working with Oregon tribes to strengthen Native American languages. 
In these classes, students read and translate stories line by line; learn Chinuk Wawa through grammar, writing, speaking and listening; and learn about Pacific Northwest history, linguistics, and linguistic anthropologists working on Pacific North West indigenous languages. This curriculum includes many culturally-relevant elements. There are lessons on how to make baskets; lessons on how to harvest hazelnut twigs and process them for basket weaving; and stories about people digging camas root, harvesting berries, and hunting elk.

\section{Portland community classes.}

As of September 2010, there were three Chinuk Wawa community classes in Portland: one in a private residence open to everyone; one as a class at the CTGR Portland Tribal office open to CTGR-enrolled tribal members and others invited to participate; and one composed of a community group focusing on writing in Chinuk. The first two community classes were both taught with the same method called 'Where are your Keys': students sit around a table with a few sticks, stones, and red and black pens, a dollar bill, and a sign-in sheet. Students practiced the language by giving or trading the objects with other students. The original developer, Evan Gardner, was interested in developing a teaching method where students would gain spoken fluency as quickly as possible in order to increase numbers of speakers of endangered languages. To achieve this he created a language game called 'Where are your keys?' This method is a tool for Native American and heritage language communities to efficiently learn then teach their languages. This method is described with examples 
and applications on their website (whereareyourkeys.org). No academic research has been done on the effectiveness of this specific technique.

Based on my involvement, I can note that the advantages of this method are that learners recycle and repeat vocabulary many times and always speak within a concrete context. Students can learn basic and more complex interactional phrases like: "Give me your pen," and "I will give you my dollar if you give me your pen" over four to eight classes. This technique incorporates instructions on how to teach as well as learn languages so more advanced students can act as teachers and can instruct newcomers.

The disadvantages of this method are that students often lose interest once the new language items have been learned. Keeping the process of learning new and exciting for higher level speakers is a challenge. Additionally, this method focuses on listening and speaking skills, with no clear method or instruction in reading and writing.

The second community class is a Chinuk Wawa writing group which meets once a month at the CTGR Tribal office after the other community class. Chinuk Wawa language learners write a poem or story and email it to the group facilitator who then offers feedback on the writing sample. This writing group has met only a few times. The intention of the group is to use compositions as a vehicle for learning Chinuk Wawa and potentially to create a bound compilation of the compositions to contribute to the revitalization effort of Chinuk Wawa. 
Much effort has been invested to create more speakers of Chinuk Wawa and to re-integrate the language into modern daily life. Understanding the motivations of some of the people involved is the question at the heart of this study.

\section{Motivation and Identity}

This section looks at research done in the areas of motivation and identity in speech communities as a basis for understanding the premises I chose to use to interpret and analyze the data in my study. Informed by this research, I used some of the analytical tools that emerged in my review of the literature as well as developing tools of analysis based on my data.

Motivation and identity are interactional and intertwining phenomena seen in individuals, communities, and societies. The following literature review highlights definitions and functions that these terms have acquired in psychology as it applies to second language acquisition (Dörnyei, 2005; Williams, 1994) and in second language acquisition (Norton, 1995, 2000; Gardner \& Lambert, 1972).

\section{Motivation.}

Motivation is a complex and multidimensional concept. According to Williams (1994), an educational psychologist working in the social constructivist paradigm, motivation involves two distinct phenomena: one, "reasons for wanting to do something" and two, "what is actually involved in acting in a motivated way" (p. 79). The first definition refers to the initial motivation for deciding to do something while the second refers to actions typical of a motivated person. In my study, I am not concerned with the second phenomenon; I am making the assumption that coming to 
class over an extended period of time is the action of a motivated person. For this study, I am concerned with participants' stated reasons for wanting to begin and continue to study Chinuk Wawa.

Williams further differentiated motivation into intrinsic and extrinsic motivation. As cited in Williams (1994), Csikszentmihalyi and Nahamura (1989) considered intrinsic motivation to be what people do because they enjoy it regardless of any rewards or punishments, and extrinsic motivation to be what a person does because of external reward or punishment. Williams pointed out that these factors most likely interact and influence each other rather than acting as dichotomous factors. My study will consider motivation as "reasons for wanting to do something," in the light of both intrinsic and extrinsic rewards.

Gardner and Lambert's (1972) distinction between instrumental motivation and integrative motivation have played a seminal role in research on motivation in second language acquisition. Gardner and Lambert completed research in Quebec, Canada, that quantitatively investigated second language learners' motivations for starting and continuing to learn a second language by using a battery of questions. According to their results, instrumental motivation is associated with the concrete benefits language proficiency may bring about, for example, job opportunities or increased pay. Integrative orientation is defined by Gardner and Lambert as "reflecting a sincere and personal interest in the people and culture represented by the other group" (1972, p. 132). Both concepts, instrumental and integrative motivation, have relevance to the participants of my study. 
Dörnyei is a more recent researcher in the field of motivation research in second language acquisition and psychology. He describes integrative orientation as a three-part construct: first, learners' interests, attitudes, and involvement in the target language community; second, students' attitudes toward the learning situation; and third, students' motivation, that is, students' effort, desire and attitudes toward learning (2005, p. 70). I have chosen to analyze my data using integrative/instrumental motivation or orientation because these concepts of motivation align closely with what I learned in the community I am describing.

The concept of integrative orientation is especially apt in this discussion on the importance of relationships in this community because it might show evidence of the learners' motivation being based on their desire to integrate into a target language community. This may be the case for at least one participant in my study. However, it is more appropriate to cite a similar phenomenon occurring in the world of English: A basic question we have begun to ask is whether we can apply the concept of integrative orientation when there is no specific target reference group of speakers. Does it make sense to talk about integrative attitudes when ownership of English does not necessarily rest with a specific community of speakers, whether native of British or American English varieties or speakers of World English varieties? (Dörnyei \& Ushioda, 2009, p. 2-3)

In the Chinuk Wawa language community, the same questions apply. There is no easily definable target community, and hence, not surprisingly, each participant had a unique orientation toward his/her idea of what or who the target community was. 
Dörnyei and Ushioda (2009) described several dimensions of second language learner motivations from students learning five target languages: English, German, French, Italian, and Russian. These dimensions included in full: milieu, self-confidence, vitality of L2 community, attitudes toward L2 speakers, cultural interest, instrumentality, and integrativeness. Several of these dimensions, vitality of L2 community, cultural interest, instrumentality, and integrativeness were motivations reported by participants in my study. Thus, I use these terms to describe some of the participants' motivations in Chapter Five.

Dörnyei described three components of the L2 motivational Self System: the Ideal L2 self, the Ought-to Self and the L2 Learning Experience. The first two components are relevant to my study and are further defined here. The Ideal L2 self "is the L2-specific facet of one's 'ideal self." Dörnyei posits that "if the person we would like to become speaks an L2, the 'ideal L2 self' is a powerful motivator to learn the L2 because of the desire to reduce the discrepancy between our actual and ideal selves" (2009, p. 29). The Ought-to Self "concerns the attributes that one believes one ought to possess to meet expectations and to avoid possible negative outcomes." To provide perspective within this discussion and research project, I include a quote from Dörnyei: "Motivation concerns the fundamental question of why people think and behave as they do, and we should never assume that we know the full answer" (2005, p. 66). 


\section{Identity.}

In the following section, I discuss concepts of identity relevant to my study. First, I discuss Williams' stated connections between language learning and identity. Then, I discuss language learner identity, social identity, and Native American Identity as each relate to my study.

There is strong evidence in second language acquisition literature that learning a new language can inform, reinforce, or shift a learner's identity in some way. Spielmann and Radnofsky (2001) state that learning a second language can be tied to

one's identity because language is used to convey one's identity to others, and learners construct a new identity in the language being learned.

Williams (1994) stated the connection between learning a new language and one's identity in this way:

There is no question that learning a foreign language is different to learning other subjects. This is mainly because of the social nature of such a venture. Language, after all, belongs to a person's whole social being; it is a part of one's identity, and is used to convey this identity to other people. The learning of a foreign language involves far more than simply learning skills, or a system of rules, or a grammar; it involves an alteration in self-image, the adoption of new social and cultural behaviors and ways of being, and therefore has a significant impact on the social nature of the learner. (p.77)

This quote anchors the results of my pilot study analysis in that identity can be a crucial piece in choosing to learn a new language. Additionally, my second guiding 
question addresses the issue of how identity relates to motivation when choosing to begin and continue to learn Chinuk Wawa.

\section{Language learner identity.}

Norton (2000) studied identity with respect to second language learners in Canada. Norton conducted a two-year, longitudinal study with five Canadian women in order to understand their investment in learning a target language. While Gardner and Lambert researched motivation in second language acquisition quantitatively, Norton used qualitative methodology. Similar to Norton's study, this study uses interviews and ethnographic techniques to gain a fuller picture of Chinuk Wawa language learners' stories and identities.

Norton defined identity as "how a person understands his or her relationship to the world, how that relationship is constructed across time and space, and how the person understands possibilities for the future" (p.5). She stated that language is a tool for expression of one's identity and paraphrased Heller (1987): "It is through language that a person negotiates a sense of self within and across different sites at different points in time" (p. 5). She introduced the term investment, which is a subset of the concept of integrative motivation. Norton described investment as follows:

The notion of investment ... conceives of the language learner as having a complex social history and multiple desires. The notion presupposes that when language learners speak, they are not only exchanging information with target language speakers, but they are constantly organizing and reorganizing a sense of who they are and how they relate to the social world. 
She continued by stating, "an investment in the target language is also an investment in the learner's own identity, an identity which is constantly changing across time and space." To further nuance the construct, Norton stated: "a learner's investment in the target language may be complex, contradictory, and in a state of flux" (p. 11). Like Williams, Norton makes an explicit connection between a learner's motivation (or investment) for learning a language and the learner's identity. Norton's study laid important groundwork for this study. Her articulation of motivation and identity sets up a useful framework for my study as she similarly examined an extended case study. Also applicable to my study are the constructs of the salience of motivation and identity as important to participants' choice to learn a language. Norton noted the shifting nature of her participants' motivations, something I also observed in this study. I use part of Norton's definition of identity, "how a person understands his or her relationship to the world" to study the identity of participants in this study.

\section{Social Identity.}

Assumptions implicit in the social constructivist paradigm, the model of this study, include a conception of identity as emergent through discourse and social interaction and dependent on context. For the purposes of my thesis, I study the identities that participants state as relevant to their motivation to learn or teach Chinuk Wawa. I follow Norton's definition as well as Bucholtz and Hall's broad definition of identity. 
Bucholtz and Hall (2005), in their review of interdisciplinary literature on identity, first defined identity as "the social positioning of self and other" (p. 586). They conceived of identity as emergent in interactions and socially and culturally

constructed rather than as an internal, individual, and static phenomenon. In my study, I consider how participants position, and, thus, identify themselves, within the Chinuk Wawa language community. I study this social positioning and creation of identity within the Chinuk Wawa language community as it relates to their motivation to learn or teach the language.

\section{Native American identity.}

Speaking a certain language is a marker of one's personal identity; it is also a marker of one's group identity. According to some Native American language activists, their tribal languages connect tribes to their history, ceremonies, and ways of life. Stephen Greymorning, in "Running the Gauntlet of an Indigenous Language Program," voiced his fears about losing his language: I am really worried if we lose our language we won't be able to think in the Arapaho way. If we lose our language we will lose our ceremonies and ourselves because our life is our language, and it is our language that makes us strong. (1999, p. 6)

Other Native language speakers echo similar sentiments. Lucille Watahomigie, a Hualapai educator, noted, "It is said that when the languages were created, language identified the people-who we are, where we came from, and where we are going" (1998, p. 6). 
These Native scholars and educators related their ability to speak their Native languages to their identity as part of a group, in this case their Native American tribes. For them, language proficiency is related to cultural proficiency.

With regard to Chinuk Wawa revitalization in Grand Ronde, similar connections have been made between language, tribal identities, and social behavior of a group. According to Davis (1998) in his Master's thesis on the CTGR community and Chinuk Wawa, if the Grand Ronde community were to learn Chinuk Wawa:

The desired results would increase community and individual pride in being different, in being "Indian." It would provide a means for reviving other traditional beliefs and practices within the "language-in-culture" model. Because of the re-establishment of traditional values and beliefs, it is hoped that there will be more family cohesiveness and greater social responsibility. (p. 76) Davis makes an explicit connection between learning a language and its possible effects on speakers' identities, beliefs, and social norms. Other contemporary Native American communities also commonly make this connection between learning their tribes' ancestral language and a strengthening of the tribes' Native American identity.

This literature review provided a foundation for understanding how Chinuk Wawa revitalization is situated within a larger national and international language revitalization movement. It also gave a brief overview of the history of Chinuk Wawa and efforts to revitalize it. This overview provides a background for understanding participants' motivations to learn or teach Chinuk Wawa as reported in Chapters Four and Five. Additionally, this review cited relevant research on motivation and identity 
and stated this study's approach to these topics as relevant to interpreting participants' reported motivations for learning or teaching Chinuk Wawa.

This information is related to larger processes, and it allows us to now step into a micro frame of a small number of teachers and learners engaging in the important activity of Chinuk Wawa revitalization. This group is engaged in language learning and teaching with a dynamic interplay of motivation and identity in motion simultaneously. Additionally, this study provides a snapshot of eight individuals all actively engaging in not simply language study, but also identity reinforcement. Given

this background, the following guiding questions focus on the issues of motivation and identity in the Chinuk Wawa language community.

\section{Guiding Questions}

The purpose of this thesis is to explore Chinuk Wawa language community members' motivation to learn Chinuk Wawa based on interviews and observations. Specifically, this thesis addresses three questions:

1. What reasons do participants directly or indirectly report for choosing to learn and/or teach Chinuk Wawa?

2. Do participants report a link between choosing to learn and/or teach Chinuk Wawa and aspects of their identity? If so, what do participants report concerning the nature of this relationship/these relationships?

3. What does Chinuk Wawa represent to the Portland Chinuk Wawa language community? 


\section{CHAPTER 3}

\section{METHODOLOGY}

This section provides a description of the overall design, the case, the role of the researcher, and the data collection and analysis procedures used in this study. Additionally, there are sections addressing trustworthiness, limitations, and implications of this thesis.

\section{Overall Design}

This study follows the instrumental case study design as described by Creswell (2007, p. 74). This model is most appropriate for my study because I am focusing on a specific issue, motivation, and the study involves one bounded system, the members of the Portland Chinuk Wawa language community who have consistently attended Chinuk Wawa classes offered in Portland for at least six months. Additionally, I use aspects of ethnographic methodology, namely participant-observation, to corroborate the findings from the questionnaires and interviews.

Ethnography is a suitable approach for this study because motivation is a complex phenomenon that requires knowing a context and community intimately. Based on my experience with this community, I explain the context of this study, an important piece in understanding motivations and identity of the participants. I use types of data that are typical of case studies: questionnaires, structured interviews, follow-up interviews, field notes from the interviews, and participant-observer notes. Through these sources of data, I provide multiple perspectives on the same 
phenomenon allowing for the triangulation of that data that strengthens my conclusions (Stake, 1995).

\section{Description of the Case}

In this section, I describe the context of the study, give a brief history of classes offered Portland from 2007-2011, and explain the selection process for the participants.

\section{Context of the study.}

There were several different Chinuk Wawa classes offered in Portland between 2007 and 2011 as detailed in previous chapters and in Table 1. In addition to the classes already discussed, two classes were offered at the Native American Youth Family Center (NAYA) from 2010 to 20111. Another teacher and I co-taught a Chinuk Wawa class at the Early College Academy, a charter high-school. Additionally, a class for community members was offered. Because these classes were short-lived and all of the students were also involved in another class, I only mention the NAYA classes here. 
Table 1

Summary of Portland Chinuk Wawa Classes

\begin{tabular}{|c|c|c|c|c|c|c|}
\hline $\begin{array}{l}\text { Portland Chinuk } \\
\text { Wawa Classes }\end{array}$ & $\begin{array}{l}\text { Length/Yea } \\
r\end{array}$ & 2007 & 2008 & 2009 & 2010 & 2011 \\
\hline $\begin{array}{l}\text { 1. Lane } \\
\text { Community } \\
\text { College Distance } \\
\text { Learning - (open } \\
\text { to all: credit/non- } \\
\text { credit students) }\end{array}$ & $\begin{array}{l}3 \text { terms - } \\
\text { fall, winter, } \\
\text { spring }\end{array}$ & $\mathrm{X}$ & $\mathrm{X}$ & $\mathrm{X}$ & $\begin{array}{l}\text { continued } \\
\text { until } \\
\text { February; class } \\
\text { restarted in } \\
\text { September }\end{array}$ & $\mathrm{X}$ \\
\hline $\begin{array}{l}\text { 2. CTGR } \\
\text { Community Class - } \\
\text { (native/non- } \\
\text { native students) }\end{array}$ & year round & $\mathrm{X}$ & $\mathrm{X}$ & $\mathrm{X}$ & $\begin{array}{l}\text { discontinued } \\
\text { in February }\end{array}$ & $\mathrm{X}$ \\
\hline $\begin{array}{l}\text { 3. CTGR } \\
\text { Community Class - } \\
\text { (CTGR enrolled } \\
\text { members only or } \\
\text { by invitation) }\end{array}$ & year round & & & & $\begin{array}{l}\text { started in } \\
\text { March }\end{array}$ & $\mathrm{X}$ \\
\hline $\begin{array}{l}\text { 4. Community } \\
\text { Class - (open to all) }\end{array}$ & year round & $\mathrm{X}$ & $\mathrm{X}$ & $\mathrm{X}$ & $\begin{array}{l}\text { March - } \\
\text { moved from } \\
\text { CTGR Portland } \\
\text { office to a } \\
\text { private } \\
\text { residence }\end{array}$ & \\
\hline $\begin{array}{l}\text { 5. NAYA } \\
\text { Community Class - } \\
\text { (open to all) }\end{array}$ & short term & & & & January-June & \\
\hline $\begin{array}{l}\text { 6. NAYA High } \\
\text { School Class } \\
\text { (NAYA Early } \\
\text { College Academy } \\
\text { Students) }\end{array}$ & school year & & & & $\begin{array}{l}\text { September - } \\
\text { June } 2011 \\
\text { (pilot class) }\end{array}$ & $\mathrm{X}$ \\
\hline $\begin{array}{l}\text { 7. Chinuk Wawa } \\
\text { reading and } \\
\text { writing group } \\
\text { (enrollment based } \\
\text { on NAYA } \\
\text { Community class } \\
\text { students) }\end{array}$ & $\begin{array}{l}\text { duration of } \\
\text { class based } \\
\text { on interest, } \\
\text { availability } \\
\text { of students } \\
\text { and } \\
\text { facilitator }\end{array}$ & & & & September & $\mathrm{X}$ \\
\hline
\end{tabular}


Participants in this study were teachers, students, and organizers who taught or attended at least one of the Portland Chinuk Wawa classes for at least six months. In this context, the roles of teachers and students were often blurred. For example, one participant studied Chinuk Wawa for two years and then taught the LCC class at the Salem site for one year. He attended Portland classes intermittently, taught two classes, the LCC class at Salem, a high school class at a Portland school, and more recently facilitated a Chinuk Wawa writing group. Most of the participants had similar mixed roles learning, teaching, and organizing Chinuk Wawa classes.

I chose to interview only teachers and students who had been involved in the program for at least six months to ensure that they were sufficiently motivated to be involved with Chinuk Wawa. My goal was to interview 6-12 teachers and students, and, in the end, I interviewed eight; these participants were self-identified as both Native and non-Native American.

\section{Role of the researcher.}

Within the social constructivist paradigm, the researcher is considered a subjective social being that is making meaning along with the participants of the study (Cresswell, 2007). The researcher is thus an integral part of her study; no clear line exists between the researcher and the participants. The rigorous research design and transparency of the researcher determines the quality of the results. The researcher carries assumptions and is socially positioned just as all social humans beings are. In an attempt for maximum transparency, the following section lays out my role, involvement, research interests, research motivations, and interpretations of the 
community. My hope is that readers better understand the lens through which I filtered the data and made interpretations.

\section{Length/degree of involvement in the Chinuk Wawa language community.}

I started attending Chinuk Wawa classes in January of 2008. I continued to attend classes as a participant-observer until September, 2011. Currently, I attend classes two to three times per month as a student. For over four years, I have been involved in the Chinuk Wawa language community in various ways, learning Chinuk Wawa, transcribing Chinuk Wawa elder speech, and teaching Chinuk Wawa.

The first class I attended, in January, 2008, was a satellite class offered at PSU through Lane Community College in Eugene, Oregon and held in the Native American Student and Community Center. After a few class meetings, the class was relocated to a small editing room which housed related equipment. This space seated only about six people comfortably.

In the spring of 2008, I attended a few sessions of community class offered weekly at the Confederated Tribes of Grand Ronde (CTGR) Tribal Office in Portland, OR. During the summer, I attended this class once or twice a month. In the fall and winter, I attended this class almost every week.

In the fall of 2008, the PSU satellite class was moved to the CTGR Portland tribal Office. I attended that class as well as the community class also held on Wednesday nights at the same place. At that time, many people came to the community classes. And often, on the same night, there would be a culture class in session where people were making traditional arts and crafts. It was a lively time at the CTGR tribal office 
with often about 20-25 people attending the language and arts and crafts classes, held in adjoining rooms. During this period, I learned that some people were not pleased by the fact that many non-tribal members and non-native people were attending the community Chinuk Wawa class and other Grand Ronde funded classes.

In February, 2010, the Portland satellite class was canceled because there were no paying credit students in the 200-level class at Lane Community College (LCC), and LCC could not sustain the Portland satellite class.

In March, 2010, the community class was no longer funded by the Confederated Tribes of Grand Ronde because of budget cuts and internal politics. The community class continued at a private residence in Northeast Portland, with no official ties to the CTGR.

By the end of the summer, the long-time instructor and developer of the 'Where are your Keys' method (see pp.17-18), passed the community class over to two dedicated students, one a CTGR enrolled member and one a non-Native American Chinuk Wawa student. The class continued until December of 2010. The class went on hiatus at that point because few people were coming to the classes and the instructors were otherwise employed.

In September, 2010, the Lane Community College 200-level Chinuk Wawa classes began again. The consulting CTGR linguist taught the LCC class from Portland by Skype in tandem with the Eugene teacher. In January 2011, the Portland satellite class found a home again at the Portland Office of the CTGR. The Portland class has been very small 
(two people) and consists of students who have studied Chinuk Wawa for at least three years already.

In January of 2011, a separate community class started again at the Portland Office of the CTGR with the successor of the community class facilitating it. This class was very informal. Mostly fairly proficient students came and spoke in Chinuk Wawa. Some people also worked on flashcards for the class or made cedar bracelets or other traditional crafts. One student brought some traditional food to share. People generally brought some food for potluck snacks, which created a more community-like atmosphere. At one class, about 10 people attended, including a family with three children, and everyone was involved in playing "Go fish" with hand-made Chinuk Wawa cards.

\section{Researcher's work with Chinuk Wawa.}

From the spring of 2009 through the summer of 2011, I did intermittent contract work for the Confederated Tribes of Grand Ronde, working closely with the consulting linguist of the CTGR. I transcribed the recordings of two elder Chinuk Wawa speakers and created transcribed databases of their speech. The recordings were a mix of English and Chinuk Wawa. One of the primary purposes of the database was to allow the consulting CTGR linguist to search the database for examples of language use to include in a dictionary of Chinuk Wawa. Another purpose of the database was to serve as an archive for the CTGR as well as the Melville Jacobs library at the University of Washington. 


\section{Researcher's interest in topic.}

Through my long-term involvement in learning Chinuk Wawa, I noticed that many people came and went from classes. Only a few stayed to really learn Chinuk Wawa and commit to its revitalization. I was interested in learning these people's motivations for their commitment to Chinuk Wawa. People involved in language revitalization have the monumental task of creating a community of speakers dedicated to bringing a language back from obscurity. Motivating others to learn Chinuk Wawa can be difficult because the reasons to invest in its revitalization are not always obvious. There is generally little economic benefit. And learning a new language takes a lot of time and dedication.

I chose this research topic partly because this research might elucidate important insights from those involved in Chinuk Wawa to strengthen the language revitalization effort. The interview portion of this thesis provided participants with an opportunity to reflect on what they were trying to achieve through their involvement. Additionally, I am inherently interested in other people's stories about their lives and how they got to where they are today.

\section{Navigating between two worlds: Academia and Native American tribes.}

Completing this research project was a long and slow process. Part of the reason for this is that I was negotiating a path between two different institutions, Portland State University and the Confederated Tribes of Grand Ronde, each with different goals and histories. 
On the one hand, academia requires research endeavors such as this thesis to undergo an approval process by a Human Subjects Committee, which reviews applications submitted by the researcher to ensure that the participants, the researcher, and the affiliated institutions are not exploited in the process of the research. The Portland State University Human Subjects Committee functions across all disciplines and departments. Additionally, the Applied Linguistics program at PSU requires the researcher to submit a proposal to the three-person faculty committee for approval.

On the other hand, in working with Native American tribes, researchers find that the process to get approval is much less clear-cut. Forming and sustaining trusting relationships between the researcher and those in charge seems to be the backbone of good working relationship with tribes. In some cases, researchers must go before a tribal council, an elected body of members of the tribe, and present a research proposal for approval by the tribal council.

In working with the CTGR, an organization with which I had less contact than with the academic world and no previous experience, I needed to get approval from the Cultural Education Coordinator of CTGR. Internal politics that were unclear to me made the process an uncomfortable and stressful one because I was never sure who I could talk to about my project. When I did get approval from the proper authority, he later left his position before I had completed the study. Thus, I needed to get permission from the next set of people in charge of similar endeavors. Getting permission from the 
requisite committees and institutions has proved to be one of the more difficult parts of this entire process.

\section{Researcher's role relationship to the participants.}

Because of the dynamic and intimate nature of this community, I found that people associated with Chinuk Wawa played multiple roles in my life over the past four years. These roles included: classmates, teachers, colleagues, boss/manager, friends, and acquaintances. With some people, I had multiple-role relationships. We were friends, classmates, and teacher/students. With others, learning Chinuk Wawa was the only point of connection and the relationship was that of classmate only.

\section{The Portland Chinuk Wawa language community.}

This community is somewhat unstable; key and peripheral people come and go. Classes often shift in terms of method of teaching, teacher, and supporting institutions. There are many reasons for this. First, politics influence the stability of this community. It is such a small community, and people have different visions about how revitalizing Chinuk Wawa should be done. Since I began to learn Chinuk Wawa, two people, a Chinuk Wawa language teacher and the Cultural Education Coordinator of

CTGR, have left due to various political and personal circumstances. Second, the level of openness of the CTGR to non-native and non-tribal members is unclear. There have been times when I felt more than welcomed to the Portland tribal office and to other related tribal events. At other times, the classes held at the tribal office in Portland have restricted attendance to only enrolled CTGR tribal members. The function of the Portland tribal office is to serve CTGR enrolled Native Americans, so it makes sense to 
restrict the availability of the classes. However, there are few people committed to Chinuk Wawa, and some CTGR members feel that whoever is interested in learning Chinuk Wawa should be welcomed because the more people speaking Chinuk Wawa, the stronger it will become.

There are just a few people who I have regularly seen over the past few years. That does not mean that there are not other people meeting and studying Chinuk Wawa that I don't know very well. There are other communities within the larger Chinuk Wawa community that seem to be based on mutual interests, similar backgrounds, or familial ties. Because of my identity as a white person who learned about Chinuk Wawa and the classes through a class called Maintenance and Revitalization of Endangered Languages offered at Portland State University, I came into learning Chinuk Wawa from a more academic avenue. Other people became interested in learning Chinuk Wawa from a cultural or traditional perspective, that is, they are also interested in learning about basketry and other Native traditional arts and crafts. These people tend to make closer bonds and meet outside of class to learn more about these things. Though I am also interested in those things, because I am currently an MA TESOL student and a new teacher, somehow, I am less involved in those aspects. Additionally, the PSU satellite class is taught by the consulting linguist at CTGR. His primary interest and passion is in the language, rather than in the associated cultural arts. His realm of interest and expertise is in the history of Pacific Northwest languages, specifically Chinuk Wawa, and cultures. Therefore, because of my initial entry into the 
community, I have built closer relationships with those people involved in the more technical, linguistic side of Chinuk Wawa.

There are other communities of people who might meet and do other things together like pick huckleberries, make baskets, or do other activities that I don't know about. I am close to a few of the people, but our main meeting place and place of community is at the classes. I have, on occasion, met up with class members or teachers outside of class, but our purpose for meeting has always been related to the community or related to doing traditional arts.

Thus, the community is made up of disparate people who lead very different types of lives. The common thread for this community is learning Chinuk Wawa. Chinuk Wawa is the nexus around which very different types of people congregate. Because Chinuk Wawa is one of the only points of connection between some members, some of the relationships within this community can be uniplex (consisting of only one social connection).

In the Portland Chinuk Wawa language community, importance is placed on membership in a local tribe where Chinuk Wawa was historically spoken. Those participants with that membership seem to be considered more legitimate participants by all participants. This may be because the classes are funded by the CTGR and specifically for CTGR tribal members, though others attend as well. Participants without that tribal membership sometimes feel the need to explain their particular interest or orientation to learning Chinuk Wawa. For instance, one participant 
repeatedly explained that he was not claiming Native identity nor claiming any cultural identity through the language.

\section{The researcher's investment in this community.}

I have gained much through my four years of being involved in Chinuk Wawa revitalization: I have learned a new language, gained a deeper knowledge and appreciation of Pacific Northwest history and culture, made new friends, earned money doing interesting work, received recognition and praise as a speaker of this language from Portland State University professors and students as well as my own family and friends, glimpsed the world of linguists trying to save an endangered language, learned about new computer software programs and fonts, taught Native American high school students, been invited to and attended several private cultural events, and learned more about the indigenous plants of this area. My experience in this community has been very rich. I deeply respect each of the participants who willingly gave of their time, thoughts, and reflections for this thesis; and in my interpretations, I fairly represent what they reported to the best of my ability.

\section{Data Collection Procedures}

\section{Interviews.}

I chose interviews as the primary source of data for this study because interviews allow participants to tell their own stories and engage in the process of making meaning from their own experiences (Siedman, 1991). I interviewed eight people in interviews that ranged in length from 40 minute to almost three hours. 
To collect the data, I arranged interviews with individuals and recorded the interviews using a digital audio recorder. I used semi-structured interview questions (see Appendix A), then audio-recorded the interviews, and finally, transcribed them. Additionally, during the interview, I took notes to record facts, events, and the circumstances under which the interviews took place (Bucuras, 2003, p. 56). The interviews were conducted at quiet locations convenient to the participants, either at the Grand Ronde Tribal Office in Portland, Oregon, or in private homes.

I conducted the interviews in March-May of 2011 and finished transcribing the interviews in July of 2011. Six of the eight participants live in the Portland metropolitan area. One participant lives about an hour south of Portland. One participant had been living about an hour south of Portland but, just before the interview, had moved about two hours away from Portland. That interview took place in a friend's house in Portland.

\section{Interviewing protocol.}

At the beginning of each interview, 1 explained the purpose of the study to the participants, and then I asked them to sign a waiver approved by the Human Subjects Review Committee at Portland State University. Next, I administered a questionnaire (see Appendix B) for the purposes of recording background information about the participants and to keep the interview data organized. Stapled to the top of the questionnaire was a short form where participants wrote their actual name and a pseudonym of their choice (see Appendix A). This is the only document linking their pseudonym to their actual name. I included a question about ethnicity in the 
questionnaire because these questions are more commonly encountered in written form but less often asked in conversation.

Because Chinuk Wawa is a language with so few speakers and lacks an easily defined target community, it was difficult to find similarly-constructed studies on which to model the interview questions. Given this reality, I used my observations as a long-time student of Chinuk Wawa to guide the structure of the interview questions. Three linguistic professors in the Portland State University "Teaching English to Speakers of Other Languages" Masters Program (PSU MA TESOL) program reviewed and commented on the questions, leading to further revision and reordering of the questions. Additionally, through conducting the pilot study I discarded some repetitive questions and then condensed the questions into seven core question sections.

These interview questions (see Appendix A) were designed to elicit responses to the guiding questions from varying angles. I chose to work with prepared questions in order to allow for greater consistency between interviews, though I asked follow-up questions during the interviews. Because many of the questions were open-ended, participants spent varying amounts of time answering the same questions.

The first section of interview questions allowed participants to broadly and uniquely frame their experience learning and/or teaching Chinuk Wawa. It served as a warm-up, allowed me to gather and record basic information about participants' attendance at Chinuk Wawa classes, and informed me about the participant's perspectives on learning and/or teaching Chinuk Wawa. 
The second section was about the participants' perspectives on studying Chinuk Wawa. The questions were designed to respond to the first research question, "What reasons do people report for choosing to learn and/or teach Chinuk Wawa?" and were framed to result in answers responding to the issue of motivation.

The third section concerned the participants' use of Chinuk Wawa, when they used it and in what capacity. These questions were adapted from Bucuras' thesis (2004). The questions provided opportunities for participants to respond to the second guiding question about how Chinuk Wawa relates to their identity.

The fourth section contained questions about learning or teaching Chinuk Wawa. The participants' responses uncovered the role of languages in their lives, specifics of learning Chinuk Wawa, and the role of Chinuk Wawa in their lives.

The fifth section concerned the perceived differences and limitations of Chinuk Wawa as compared to English or other languages. By comparing stories in Chinuk Wawa to stories in English or other languages, participants had the opportunity to contrast Chinuk Wawa with other languages, revealing more about their motivation for studying Chinuk Wawa.

The sixth section included questions that asked participants to make connections between Chinuk Wawa and their family and/or Chinuk Wawa and their sense of place. To further elaborate on issues of motivation and identity, I adapted the questions from Bucuras' interview questions (2004) in order to learn more about ties with ancestry for self-identified Native American people or a connection to place for self-identified non-Native participants. 
The seventh and final section included questions specifically for teachers. I included this section because, as teachers, these participants were perhaps more invested in the Chinuk Wawa language community and may have had more to say than those participating solely as a learner. The questions were intentionally open-ended and broad in order to allow and challenge the participants to frame their responses without prompting from the researcher.

At the end of each interview, I thanked the participant for sharing his/her time and perspectives with me, and I explained what I planned to do with the data. Next, I made sure they understood their rights as participants in this study. Finally, I asked if participants would be willing and able to meet with me again for a follow-up interview for member-checking, where the researcher takes provisional findings to the participants who give information about the case that confirm, correct, amend, or extend the researcher's analysis of the case (Lincoln \& Guba, 1985, p. 236). As a participant-observer in this study, gaining access to the participants and conducting interviews was an easier process than if I had not had previous connection with the community or the participants. Because of the history of exploitation of academics working with Native American communities, I attempted to ensure that participants knew what I planned to do and that this study benefitted them as well as the academic community. Additionally, through the member-checking, each participant was able to have a voice in determining the final content of this study. 


\section{Participant-observer notes.}

The final form of data was field notes that I took as a participant observer in the classes. The purpose of this data was to enhance the detailed, rich, thick description of the class as well as corroborate participants' responses in the interviews. Since my presence was expected in the classroom, it did not change topics covered or behavior in the class.

Cresswell describes a participant-observer as immersed in the day-to-day lives of the people, observing and interviewing group participants (Cresswell, 2007, p. 68). In this case study, I was immersed in one shared aspect of the participants' lives, that of the Chinuk Wawa classes. I consistently attended several Chinuk Wawa classes over three years (LCC class at PSU and CTGR office, community class at CTGR office and private residence), for the first three years as a participant, and the last year as a participant-observer. In the last year, my role varied from a full participant to a partial participant and partial observer (Cresswell, 2007, p. 130). Because of my long-term involvement with these people and these classes, my presence was expected. I do not describe myself as an insider in this community only because I do not have the sense of there being a unified community. Rather, I am connected to people who have insider status through their connections to the Grand Ronde community. During the summer

of 2011, while this research was conducted, I was finishing a project where I transcribed recordings from the early 1980's of a Grand Ronde elder speaker. I was working under the supervision of one of the participants of this study. So, for several weeks, while I was at the classes as a participant-observer, I was also a participant working on a 
Chinuk Wawa documentation project. I observed the LCC distance-learning class and the community class taught in adjacent rooms on Wednesday nights. I observed the classes over a period of seven months (April-October 2011). During this time, I took participant-observation notes on 18 of the classes.

My method of note-taking evolved through practice. While first collecting field notes, I wrote down more information than I actually used. I recorded times participants came and left class, grammar and content covered in the class curricula, and my own reflections on the participants' involvement in the classes. However, while doing the initial description and analysis of the case, I found that much of the notes were extraneous to my research purposes. Therefore, for subsequent field notes, I focused on the areas that were directly relevant to my study: which participants attended the classes, what activities each participant was engaged in, conversations between people, and what objects participants brought. This data allowed me to triangulate results I found through interview transcripts.

\section{Data Analysis Procedures}

\section{Pilot study.}

In preparing to do this research, I interviewed two people who attended four to six classes of Chinuk Wawa. Through these preliminary interviews, I field-tested interview questions and practiced my interviewing skills. I coded the interview transcripts based on the themes that emerged in the preliminary analysis (see Appendix D). I divided the broad category motivation into emergent sub-categories to capture the breadth and overlaps of the various types of motivation. These categories 
of motivation included: geographic place; linguistic orientation; aspects of identity including social orientation, cultural orientation, and orientation towards language learning; and demotivating obstacles that prevented students from continuing to learn Chinuk Wawa. I came up with these categories based on interviewees' responses, except the category of identity. These categories were based on the literature about identity (Bucholtz \& Hall, 2005; Norton, 2000). For the purposes of the pilot study, the categories (see Appendix D) were sufficient because they encompassed all of the interviewees' reported motivations. The category of place refers to interviewees' desires to learn Chinuk Wawa because it was historically spoken in the Pacific Northwest. One interviewee reported that learning Chinuk Wawa seemed appropriate because she was living in Portland, a place where the language was historically spoken. The category of linguistic orientation referred to interviewee's motivations to study Chinuk Wawa in order to be able to communicate in specific domains (e.g. the Canoe Journeys ${ }^{3}$ ) or to try learning a new language full of different sounds. The identity category included interviewees' motivations to learn Chinuk Wawa relating to their concept of themselves or their social networks, thus, social orientation. The cultural category referred to the choice to learn Chinuk Wawa as related to cultural aspects of the interviewees' lives, for example, as a way to reconnect with core tribal values. The orientation to language learning referred to interviewees' experiences or attitudes with

\footnotetext{
${ }^{3}$ The Canoe Journey is a journey taken by tribes of the Pacific Northwest to a specific destination. Planning occurs through the year and the journey itself usually takes ten days. http://tribaljourneys.wordpress.com/tag/canoe-journey-2012/
} 
learning a new language in general. One interviewee reported that part of her desire to learn Chinuk Wawa was because of the teaching method used. Finally, the category demotivating obstacles served to illuminate the reasons that the interviewees discontinued their Chinuk Wawa studies. I used these categories as a starting point for the analysis of interviews for this larger project, but I did not use data from these interviews in this thesis.

Through the interviews, I found I needed to reconsider how I framed participants' ethnic identities. One participant came from a family with a Native American father and a white mother, and she fully identified as culturally and ethnically Native American. Before the interview, I had assumed the second participant was white; however, during the interview she shared with me that her ethnic identity included a Cherokee ancestor, though she did not identify herself as a culturally Native American. Through this experience, I realized that the Native/Non-Native identification is not a dichotomous distinction. Therefore, for the thesis interviews, I specifically asked participants to self-identify their ethnicity thus minimizing ambiguity. Additionally, by asking participants to identify their ethnicity themselves, the participants were able to choose the level of anonymity they desired. For example, the Native American participants in the study all identified themselves simply as Native American rather than by their tribal affiliations.

The participants from the pilot study, not surprisingly, framed their responses to questions quite differently from each other. One participant talked about learning the language with an emphasis on the linguistic and language learning aspects. Her 
focus may have been due to the fact that she was more familiar with identifying with Chinuk Wawa through the avenue of linguistics and as a language student rather than through her ethnic identity. The self-identified Native participant focused more on aspects of her Native identity including her family, participating in the Canoe Journey, and talking about a Native storytelling event. Through the pilot studies, I found that each participant framed her responses based on her life experiences and cultural upbringing.

In the pilot study analysis, I considered how participants framed their responses. Identity was the most salient category within the broader category of motivations. By most salient, I mean that the number of times interviewees mentioned aspects of their identity as motivating exceeded other mentioned motivations. The reasons for this may be that the interview questions were designed to broach the subject of the participants' identity as it related to Chinuk Wawa. Thus, one potential limitation of this study was that I framed the questions so that participants' identities would emerge in order to answer the guiding questions. However, the questions were broad enough to allow participants to frame their responses uniquely and individually. Participants seemed to focus on the most motivating aspects of learning Chinuk Wawa for them regardless of the questions. This pilot study captured a snapshot of two Chinuk Wawa students' reported motivations for learning Chinuk Wawa and laid the groundwork for my thesis. 


\section{Data analysis procedures of current study.}

To analyze the data, first, I read the interview transcripts and made preliminary notes based on my impressions. Next, I looked at the emerging themes that directly or indirectly responded to the guiding questions and assigned preliminary codes that correlated with these themes. I chose the themes based on both the quantity and quality of their mention within the transcripts. I included themes that participants mentioned multiple times. Additionally, I included codes that participants explicitly cited as being important motivations for their involvement with Chinuk Wawa. I then coded the data, based on these emergent themes that identified the major trends within the data. After I made preliminary codes, I printed each transcript on a different color of paper and cut out the quotes that represented each code, organizing them according to the code I had assigned them. This allowed me to easily look at all the codes within a theme in order to best represent that theme in writing. Next, I began writing up my preliminary analysis and interpretations as a way to further explore the data and develop my conclusions.

\section{Peer debriefing/coding check.}

Once I was confident in my coding process, I conducted a two hour peerdebriefing session with a colleague. I chose a colleague of the MA TESOL program who was also involved in the Chinuk Wawa language community of Portland, Oregon and had completed her thesis on a topic concerning this community. Because of her experience with both the community and qualitative research, she was an excellent candidate for completing checking my coding process. Additionally, I know her to be 
invested in both the Portland Chinuk Wawa community as well as the academic community, and I could trust the integrity of her work and of our discussion.

I emailed her a one to two page sample of each of the eight transcripts, a summary of each theme, as well as a list of all of the themes, categories and subcategories. I had highlighted the sections of the transcripts where I had found codes

and typed an empty bracket for her to fill with her selection of a theme, category, or sub-category. She filled in the blank brackets and also added her own codes in places where she thought it relevant. Since she lives in another state, we met online through Skype. First, she would tell me which code she had chosen, and then I would tell her my choice. If we disagreed, we discussed our differences of opinion. In most cases we agreed on the codes. In instances where she chose another code, she often came to agree with me once I explained my logic.

We agreed on the themes $98 \%$ of the time, based on a total of 51 codes. Eighteen percent of the time, we agreed on one code, and a she saw another possibility as well. Through explaining the full parameters of each theme, we were able to come to a close agreement. Finally, in nine out of 50 cases, $18 \%$ of the time, she chose more than one option with one option falling into the same category as my choice and another falling into another category. Using her feedback, I improved the descriptive language in Chapter Four so that my meaning could be more readily understood.

\section{Member-checking.}

After writing provisional results, I shared my interpretations in follow-up interviews (i.e. member-checking) with all of the participants. I met with six of the 
eight participants face-to-face and recorded our conversations. With two participants, I communicated via email and telephone to discuss my interpretations. Based on the results from Chapter Four, I compiled a document that included each participant's quotes used in Chapter Four and my interpretations of those quotes. I gave each person a copy of their quotes and my interpretations. They read it over, and then we discussed each one. In all of the cases, the participants agreed with my interpretations and approved of using most of the quotes within the thesis. I removed a few quotes based on participants' requests. In several cases, though they agreed with my interpretations, participants offered editing suggestions for my interpretations in order to clarify their meanings. I integrated their comments and suggestions into the discussion of results of this study.

\section{Trustworthiness of Study}

In working to ensure the trustworthiness of this study, I followed Lincoln and Guba's (1985) criteria. They describe trustworthiness as the way researchers persuade their audience "that the findings of an inquiry are worth paying attention to, worth taking account of" (p. 290). They operationalize trustworthiness according to standard procedures or techniques "that make it more likely that credible findings and interpretations will be produced" (p. 301). These techniques are referred to by Lincoln and Guba as the credibility of the study. The credibility of this study was ensured through several of these techniques detailed below.

I engaged in activities that increased "the probability that credible findings" would be produced: prolonged engagement with the community (three and a half years 
involvement), persistent observation (participant-observer notes), and triangulation where I used multiple sources of data (interviews and participant-observer notes). As a student in the classes for more than three years, I included a detailed description of this case (i.e. the Portland Chinuk Wawa language community) with the goal of giving my readers a deeper understanding of this case. I used my notes to reinforce my memories and experiences.

I further established credibility through a peer debriefing session, as detailed earlier in Chapter Three, with a colleague familiar with qualitative research and the community under study. Peer debriefing "is a process of exposing oneself to a disinterested peer in a manner paralleling an analytic session and for the purpose of exploring aspects of the inquiry that might otherwise remain only implicit within the enquirer's mind" (Lincoln \& Guba, 1985, p. 308). This exercise provided an external check of my findings.

In order to check the credibility of my findings, I engaged in member-checking, "an activity providing for the direct test of findings and interpretations with the human sources from which they have come-the constructors of the multiple realities being studied" (Lincoln \& Guba, 1985, p. 301). Namely, I checked my interpretations of the data (i.e. member-checking) with all of the participants. Through these techniques to determine credibility, this study considers the issue of motivation in the Portland Chinuk Wawa language community. 
In Chapter Three, I described the case, the role of the researcher, and the methods of data collection and analysis. This provides the framework for Chapters Four and Five where I discuss the results of the data based on seven themes of motivation. 


\section{CHAPTER 4}

\section{DISCUSSION OF THE DATA}

In this chapter, I describe the seven most prevalent themes that emerged in the coding process as well as the categories and sub-categories within those themes. I then describe themes that overlapped with others in interesting ways. Next, I discuss participants' motivations as they shifted over time as well as my participant-observer notes. I finish with a summary of the discussion of the data.

Through coding and analyzing the data, numerous themes emerged showing participants' most important motivations for learning Chinuk Wawa. I selected seven

themes from the interview transcripts that encompassed the participants' motivations based on their explicit statement of factors motivating them and frequency of occurrence. All of these themes emerged from the data and are participants' stated or implied motivations to learn and/or teach Chinuk Wawa:

Theme 1: Chinuk Wawa as a way to connect to Native culture, the Pacific Northwest (PNW), and to participants' spirituality;

Theme 2: Preservation/maintenance/revitalization of historical knowledge/Chinuk Wawa/Native culture;

Theme 3: Relationships/belonging to a community; Theme 4: Instrumental Motivation - Learning Chinuk Wawa to achieve a specific goal; Theme 5: Affective Motivations - A love for or interest in the language; as a moral responsibility;

Theme 6: Self-Ascribed Identity as a member of the Chinuk Wawa language community; 
Theme 7: Demotivation - Reasons for not continuing to learn/teach Chinuk Wawa or reasons that made continuing to learn/teach Chinuk Wawa difficult or demotivating; I ordered the themes in this way for specific reasons in some cases, randomly in others. First, I put the theme of Connection first because it was the most frequent code mentioned across all participants' transcripts. I put the theme of Preservation second because it is closely related to the theme of Connection. I randomly ordered the themes of Relationships, Instrumental Motivation, and Affective. I ordered the theme of Identity next because it built upon the previous themes. The final theme of Demotivation addressed an opposing orientation to motivation so I included it last in an attempt to separate it from the rest. Table 2 shows the occurrence of the themes of motivation across participants where ' $\mathrm{X}$ ' represents a participant's mention of a theme, and the highlighted boxes represent themes not mentioned by a participant. Table 3 provides a cohesive list of all the themes, categories, and sub-categories as a reference. 
Table 2

Occurrence of Themes across Participants

\begin{tabular}{|l|l|l|l|l|l|l|l|}
\hline THEMES OF MOTIVATION & $\begin{array}{l}\text { CONNEC- } \\
\text { TION } \\
\text { VATION }\end{array}$ & $\begin{array}{l}\text { RELATION- } \\
\text { SHIPS }\end{array}$ & $\begin{array}{l}\text { INSTRU- } \\
\text { MENTAL }\end{array}$ & $\begin{array}{l}\text { AFFEC- } \\
\text { TIVE }\end{array}$ & IDENTITY & $\begin{array}{l}\text { DEMOTI- } \\
\text { VATION }\end{array}$ \\
\hline PARTICIPANTS & & $\mathrm{X}$ & $\mathrm{X}$ & $\mathrm{X}$ & $\mathrm{X}$ & $\mathrm{X}$ & $\mathrm{X}$ \\
\hline $\begin{array}{l}\text { Keyskeys } \\
\text { Non-Native } \\
\text { Non-Native }\end{array}$ & $\mathrm{X}$ & $\mathrm{X}$ & $\mathrm{X}$ & $\mathrm{X}$ & $\mathrm{X}$ & $\mathrm{X}$ & $\mathrm{X}$ \\
\hline $\begin{array}{l}\text { Kanim } \\
\text { Non-Native }\end{array}$ & $\mathrm{X}$ & $\mathrm{X}$ & $\mathrm{X}$ & $\mathrm{X}$ & $\mathrm{X}$ & $\mathrm{X}$ & $\mathrm{X}$ \\
\hline $\begin{array}{l}\text { Nettle } \\
\text { Non-Native }\end{array}$ & $\mathrm{X}$ & $\mathrm{X}$ & & $\mathrm{X}$ & & $\mathrm{X}$ & $\mathrm{X}$ \\
\hline $\begin{array}{l}\text { ShawashB } \\
\text { Native }\end{array}$ & $\mathrm{X}$ & $\mathrm{X}$ & $\mathrm{X}$ & $\mathrm{X}$ & $\mathrm{X}$ & $\mathrm{X}$ & $\mathrm{X}$ \\
\hline $\begin{array}{l}\text { Charley Horse } \\
\text { Native }\end{array}$ & $\mathrm{X}$ & & $\mathrm{X}$ & $\mathrm{X}$ & $\mathrm{X}$ & $\mathrm{X}$ & $\mathrm{X}$ \\
\hline $\begin{array}{l}\text { Kakwa tsiltsil } \\
\text { Non-Native }\end{array}$ & $\mathrm{X}$ & $\mathrm{X}$ & $\mathrm{X}$ & $\mathrm{X}$ & $\mathrm{X}$ & $\mathrm{X}$ & $\mathrm{X}$ \\
\hline $\begin{array}{l}\text { T-1 } \\
\text { Native }\end{array}$ & & & $\mathrm{X}$ & & $\mathrm{X}$ & \\
\hline
\end{tabular}


Table 3

Themes, Categories, and Sub-categories showing Participants' Motivations for Learning and Teaching Chinuk Wawa.

\begin{tabular}{|c|c|c|}
\hline THEMES & CATEGORIES & SUB-CATEGORIES \\
\hline \multicolumn{3}{|c|}{ Theme 1: Connection } \\
\hline & $\begin{array}{l}\text { Connection to PNW Native } \\
\text { Culture }\end{array}$ & \\
\hline & & $\begin{array}{l}\text { Connection to Native } \\
\text { Ancestors }\end{array}$ \\
\hline & & $\begin{array}{l}\text { Connection to PNW Native } \\
\text { Traditions }\end{array}$ \\
\hline & & $\begin{array}{l}\text { Chinuk Wawa as encoding } \\
\text { another way of thinking } \\
\text { and being }\end{array}$ \\
\hline & & $\begin{array}{l}\text { Connection to Pacific } \\
\text { Northwest History } \\
\text { through using Chinuk } \\
\text { Wawa }\end{array}$ \\
\hline & $\begin{array}{l}\text { Connection to the Pacific } \\
\text { Northwest Region }\end{array}$ & \\
\hline & & $\begin{array}{l}\text { Connection to the } \\
\text { Pacific Northwest } \\
\text { region }\end{array}$ \\
\hline & & Connection with the earth \\
\hline & $\begin{array}{l}\text { Connection to } \\
\text { participants' spirituality }\end{array}$ & \\
\hline \multicolumn{3}{|l|}{$\begin{array}{l}\text { Theme 2: } \\
\text { Preservation }\end{array}$} \\
\hline & Preserving Chinuk Wawa & \\
\hline & & $\begin{array}{l}\text { Preserve Chinuk Wawa } \\
\text { because it is an } \\
\text { endangered language }\end{array}$ \\
\hline & & $\begin{array}{l}\text { Preserve Chinuk Wawa for } \\
\text { future generations }\end{array}$ \\
\hline & & $\begin{array}{l}\text { Expand the area where } \\
\text { Chinuk Wawa is currently } \\
\text { spoken to reflect historical } \\
\text { norms of the late } 1800 \mathrm{~s}\end{array}$ \\
\hline
\end{tabular}




\begin{tabular}{|c|c|c|}
\hline & & $\begin{array}{l}\text { Efforts to preserve Chinuk } \\
\text { Wawa }\end{array}$ \\
\hline & & $\begin{array}{l}\text { Preserving Chinuk Wawa } \\
\text { for the Grande Ronde } \\
\text { Tribal Community }\end{array}$ \\
\hline & & $\begin{array}{l}\text { A supporting relationship } \\
\text { as a motivating factor }\end{array}$ \\
\hline & $\begin{array}{l}\text { Chinuk Wawa } \\
\text { preservation as a gateway } \\
\text { to other Oregon Native } \\
\text { languages }\end{array}$ & \\
\hline & $\begin{array}{l}\text { Preserving Chinuk Wawa } \\
\text { as a way to honor and } \\
\text { respect Elders }\end{array}$ & \\
\hline & $\begin{array}{l}\text { Preserving Chinuk Wawa } \\
\text { as a nexus for preserving } \\
\text { important connections }\end{array}$ & \\
\hline $\begin{array}{l}\text { Theme 3: } \\
\text { Relationships }\end{array}$ & & \\
\hline & $\begin{array}{l}\text { Relationships as } \\
\text { motivating participants to } \\
\text { come to classes initially }\end{array}$ & \\
\hline & $\begin{array}{l}\text { Relationships as } \\
\text { motivating participants to } \\
\text { continue with Chinuk } \\
\text { Wawa }\end{array}$ & \\
\hline & $\begin{array}{l}\text { Acceptance in a } \\
\text { community }\end{array}$ & \\
\hline & $\begin{array}{l}\text { Learning Chinuk Wawa } \\
\text { because of involvement } \\
\text { with tribal community }\end{array}$ & \\
\hline $\begin{array}{l}\text { Theme 4: } \\
\text { Instrumental } \\
\text { Motivation }\end{array}$ & & \\
\hline & $\begin{array}{l}\text { Using Chinuk Wawa for } \\
\text { career/ } \\
\text { professional/making a } \\
\text { living as a teacher/linguist }\end{array}$ & \\
\hline & $\begin{array}{l}\text { Using Chinuk Wawa as a } \\
\text { political tool }\end{array}$ & \\
\hline
\end{tabular}




\begin{tabular}{|c|c|c|}
\hline & $\begin{array}{l}\text { Using Chinuk Wawa to fulfill } \\
\text { academic requirements }\end{array}$ & \\
\hline & $\begin{array}{l}\text { Using Chinuk Wawa as a test case } \\
\text { for a unique language teaching } \\
\text { method }\end{array}$ & \\
\hline & $\begin{array}{l}\text { Chinuk Wawa as a local language } \\
\text { available for study and } \\
\text { involvement }\end{array}$ & \\
\hline & $\begin{array}{l}\text { Learning Chinuk Wawa to gain } \\
\text { access to people/ a community }\end{array}$ & \\
\hline \multicolumn{3}{|l|}{$\begin{array}{l}\text { Theme 5: Affective } \\
\text { Motivation }\end{array}$} \\
\hline & $\begin{array}{l}\text { Affective Motivation (i.e. interest } \\
\text { in/like/love of the language } \\
\text { itself) }\end{array}$ & \\
\hline & $\begin{array}{l}\text { Affective Motivation as a moral } \\
\text { responsibility }\end{array}$ & \\
\hline \multicolumn{3}{|l|}{ Theme 6: Identity } \\
\hline & $\begin{array}{l}\text { Tribally-Affiliated (teachers, } \\
\text { community organizers) }\end{array}$ & \\
\hline & $\begin{array}{l}\text { Non-tribally affiliated linguists, } \\
\text { language teachers, plant people }\end{array}$ & \\
\hline \multicolumn{3}{|l|}{$\begin{array}{l}\text { Theme 7: } \\
\text { Demotivation }\end{array}$} \\
\hline & $\begin{array}{l}\text { Attitude about time spent in } \\
\text { front of computer }\end{array}$ & \\
\hline & The time commitment & \\
\hline & Lack of financial support & \\
\hline & $\begin{array}{l}\text { Appropriate use of Chinuk Wawa } \\
\text { in non-Native, not historically } \\
\text { traditional contexts and issues of } \\
\text { cultural appropriation }\end{array}$ & \\
\hline & $\begin{array}{l}\text { Attitudes about Chinuk } \\
\text { Wawa as a pidgin } \\
\text { language/partially Native } \\
\text { American language }\end{array}$ & \\
\hline
\end{tabular}


Each participant had a unique story and at least a slightly different orientation to Chinuk Wawa. Each participant's exposure to Northwest Native American history, culture, and languages differed greatly. Some participants had studied other Northwest Native American languages previously or concurrently with learning Chinuk Wawa. Some had read myths in English from Northwest tribes. A few were deeply involved in current events related to Pacific Northwest tribes while others were not. Everyone reported multiple types of motivations. Although some themes are overlapping, I chose to include all of them because they each emphasize a different aspect of this complex language community. For example, the theme of Relationships is closely related to the theme of Preservation because to preserve a language, one needs a community where people have strong relationships.

In the following paragraph, I include a brief description of participants' processes for choosing a name. Participants' choices of pseudonyms were sometimes a random or humorous choice whereas in other cases I think it revealed a passion or a belief regarding Chinuk Wawa. Each participant chose his or her pseudonym before beginning the interviews. Billy and Charley Horse picked their names quickly and with laughter. They did not seem to be worried about creating a particular image of themselves. Nettle chose this name after we discussed different possibilities for a few minutes, and I suggested the name 'Nettle' since we were both drinking nettle tea at the time. Keyskeys asked me during the second interview to change the pseudonym and settled on 'Keyskeys,' which is an older orthographic representation of the Chinuk Wawa word for the blue jay, a local bird. T-1 chose this pseudonym while chuckling 
about being a part of a research study. T-1 was not particularly concerned about remaining anonymous, though the name, 'T-1,' suggests wanting to remain unknown. ShawashB chose this name quickly and easily without my help. A rough translation of ShawashB is 'IndianB' or 'NativeB.' Similar to most of the participants, ShawashB explicitly stated that maintaining anonymity was not a concern and chose one to humor me. Kanim chose a pseudonym while we were sitting on her back porch preparing to do the interview. A hummingbird flew by and Kanim thought of using the Chinuk Wawa word for hummingbird. Instead, this participant settled on the word 'kanim' [translation: canoe] perhaps because Kanim had a cedar tree in the backyard, and Pacific Northwest peoples traditionally make canoes from cedar trees. Kakwa tsiltsil [translation: brodea] chose as a name, a Chinuk Wawa word that I did not know. The fact Kakwa tsiltsil knew this word points to his interest in plants. I suspect this choice related to this participant's interest in reviving Pacific Northwest traditional native plants as well as a passion for revitalizing Chinuk Wawa.

Table 4 provides a list of the participants' pseudonyms and details about their level and length of involvement in the Portland Chinuk Wawa language community. The group of participants consisted of two females and six males between the ages of 30 and 70. By 'tribally-affiliated,' I mean that the participant was an official member of a Pacific Northwest Indian Tribe. This included tribes that were not officially recognized by the U.S. Government. 
Table 4

Participants' Pseudonyms and Length of Involvement in the Portland Chinuk Wawa Language Community as of spring 2011

\begin{tabular}{|c|c|c|c|c|c|}
\hline $\begin{array}{l}\text { Participants' } \\
\text { Pseudonyms }\end{array}$ & $\begin{array}{l}\text { Length of } \\
\text { Time } \\
\text { Involved in } \\
\text { Chinuk Wawa }\end{array}$ & Student & Teacher & $\begin{array}{l}\text { Organizer } \\
\text { of Chinuk } \\
\text { Wawa } \\
\text { classes }\end{array}$ & $\begin{array}{l}\text { Tribal } \\
\text { Affiliation }\end{array}$ \\
\hline Billy & 4 years & Yes & Yes & Yes & None \\
\hline Charley Horse & $\begin{array}{l}5 \text { years - } \\
\text { intermittent }\end{array}$ & Yes & Yes & Yes & $\begin{array}{l}\text { Tribally- } \\
\text { affiliated, } \\
\text { Native } \\
\text { American }\end{array}$ \\
\hline ShawashB & $\begin{array}{l}9 \text { years - } \\
\text { intermittent }\end{array}$ & Yes & Yes & Yes & $\begin{array}{l}\text { Tribally- } \\
\text { affiliated, } \\
\text { Native } \\
\text { American }\end{array}$ \\
\hline Keyskeys & $\begin{array}{l}\approx 19 \text { years } \\
\text { cumulative } \\
\text { (10 years off } \\
\text { between } \\
\text { decades) }\end{array}$ & Yes & Yes & No & None \\
\hline Kanim & 2 years & Yes & No & No & $\begin{array}{l}\text { Native } \\
\text { American, } \\
\text { not } \\
\text { tribally- } \\
\text { affiliated, }\end{array}$ \\
\hline Kakwa tsiltsil & 2.5 years & Yes & Yes & No & None \\
\hline $\mathrm{T}-1$ & $\begin{array}{l}6 \text { years } \\
\text { seriously } \\
\text { involved; }+10 \\
\text { years - casual } \\
\text { involvement }\end{array}$ & Yes & Yes & Yes & $\begin{array}{l}\text { Tribally- } \\
\text { affiliated, } \\
\text { Native } \\
\text { American }\end{array}$ \\
\hline Nettle & $\approx 10$ years & Yes & Yes & Yes & None \\
\hline
\end{tabular}




\section{Interview Results}

Theme 1: Connection to Pacific Northwest Native culture, the Pacific Northwest region, and to participants' spirituality.

This theme addresses ways that Chinuk Wawa connected participants on very personal levels to several threads: Pacific Northwest Native American culture, the Pacific Northwest region, and to their own spirituality. Sieberg (2002) included a similar theme, Connection to roots, in his discussion of language maintenance and ethnic identity in the Portland Estonian-American community. Native participants and non-Native participants differed in their orientation to this theme in interesting ways. Native participants spoke connections Chinuk Wawa allowed them to make related to their Native ancestors and culture. Both Native and non-Native participants discussed Chinuk Wawa with respect to a different worldview and PNW regional history. NonNative participants spoke about how Chinuk Wawa connected them to the region and the earth.

\section{Connection to Pacific Northwest Native culture.}

Connection to Native ancestors.

Speaking Chinuk Wawa was a way to connect to Native ancestors for two Native participants. T-1 stated that speaking Chinuk Wawa was significant because his grandparents and other now deceased relatives spoke it:

I think it's kind of like an honor, 'cause not a lot of people speak it these days. And I think it's just kind of out of respect and a recognition of them [ancestors] to speak it today, to keep it going. (T-1) 
In Chinuk Wawa we usually say 'anqati' but in the old Chinook, it's 'anqatix,' and my great-uncle would say 'anqatix' instead of 'anqati.' So, those are probably are two key words for me, tied to my family and then to our tribe and our way of living. (T-1)

For $\mathrm{T}-1$, Chinuk Wawa represented a way to connect to his great-uncle through shared words, as well as to his tribe and his Native traditions.

ShawashB, another Native American participant, made a direct connection between the language and his ancestors who historically spoke Chinuk Wawa. He responded to a question about speaking the language spoken by his ancestors by stating: “Well, I think it's wonderful. It's wonderful for the tribe, it's wonderful for me. It gives me that connection to my ancestors, a connection which is really hard to find" (ShawashB). Later on in the interview he said "Chinuk Wawa is my ancestors' voice" (ShawashB).

Both T-1 and ShawashB were motivated to connect to their ancestors, known and unknown, through speaking Chinuk Wawa. They were intrinsically motivated because of their ethnolinguistic affiliations. Motivation because of ethnolinguistic affiliations is found in the literature. Littlebear, a Cheyenne Native American and scholar, (1999) discussed the importance of knowing and speaking Cheyenne because linked him to his ancestors both linguistically and spiritually. Segalowitz, Gatbonton, and Trofimovich studied the connection between ethnolinguistic affiliation and motivation with adult Francophone users of English in Quebec and found links between the two (2009). Triantafillidou and Hedgcock (2007) studied heritage learners of Modern 
Greek in the United States and found that the Greek American learners in their study "expressed a desire to develop their proficiency in Greek as a means of establishing a closer connection to their sociocultural heritage" (p. 20). Similarly, T-1 and ShawashB were motivated to learn Chinuk Wawa as a means to strengthen their connection to their sociocultural roots.

Connection to Pacific Northwest Native traditions.

Three participants stated that keeping the language alive, knowing it, and speaking it connected them to Pacific Northwest Native cultural traditions. For the two tribally-affiliated participants in this group, a connection to their ancestors' traditions motivated them to continue being involved with Chinuk Wawa revitalization. ShawashB stated his motivation to connect to his ancestors' traditions in the following way: "The language is going to help us connect and re-connect with our traditional ways" (ShawashB). When asked what learning Chinuk Wawa had been like for him, he said: "It, it's been a good experience. Our ancestors obviously thought there was something important about Chinuk Wawa, important enough to make it the language of the reservation, because somebody from every family obviously spoke some Chinuk" (ShawashB). T-1 mentioned that he was motivated to learn Chinuk Wawa because he gained insight into his Native traditions and culture: "Well, I'm really interested in the cultural perspectives." (T-1)

Nettle, a non-Native participant, spoke of going to a winter gathering near Portland where Pacific Northwest Indian tribes share stories, songs, dances and food. He spoke about Native people connecting with their past through Chinuk Wawa: 
And you really kind of feel the energy of the room change when somebody on the floor starts speaking Wawa. Because it's like, "Oh right, that's a touch to our past. That's our old thought, that's our old way, our tradition, our hearts. (Nettle)

To these three participants, Chinuk Wawa was an important way to connect with Pacific Northwest Native traditions and connect with traditions that differentiate the Native from the non-Native world. By choosing to speak Chinuk Wawa rather than their first language, English, these participants were actively orienting themselves towards Native traditions historically associated with Chinuk Wawa and other indigenous languages from the Grand Ronde reservation and the Pacific Northwest.

Chinuk Wawa as encoding another way of thinking and being.

Three participants talked about how speaking Chinuk Wawa revealed an alternative way of thinking and being. Kanim talked about how learning Chinuk Wawa had expanded her breadth of perspectives on the world. During the interview, she spoke animatedly and passionately about this experience because it had fueled her motivation to learn Chinuk Wawa: "Now I feel like everything I've been looking at all those years now has a voice and it's speaking. I feel like I can suddenly hear everything in a new way" (Kanim). Kanim then described the movie scene where Helen Keller, a blind and deaf woman, came to understand the sign language symbol for water, her first experience of language. Similarly, Chinuk Wawa had given Kanim a new experience of language: 
So that kind of opened my mind, in listening to the natural world, and one another and all that. We're a part of it....So it's been kind of expanding my mind. It feels like all these rooms in there are suddenly open that were closed before in my mind. (Kanim)

Kanim spoke about concepts uniquely encoded in Chinuk Wawa. The words for 'think' and 'feel' are the same word in Chinuk Wawa, and Kanim equated that with representing how originators of the language thought and experienced their world. Kanim revisited the idea of Chinuk Wawa revealing different ways of thinking and being:

I feel like language has happened even though I've been speaking English all my life, but suddenly a new level of language has happened. And I can say to the crow, language that the crows have heard before here, faxayam k'a k'a [translation: hello crow]. (Kanim)

She responded to a question about what learning Chinuk Wawa has been like for her by saying:

It's been like coming home because to me ... someone [Roberta Connor, Director, Tamastslikt Cultural Institute] said that the indigenous languages are the ecosystems speaking, like they encode the relationship between people and the land. And I think that's true and so this being a language that's based on languages from here, it feels like everything that I've always known is-, now I can suddenly understand their language. (Kanim) 
According to T-1, Chinuk Wawa was important because it expressed meanings that were not translatable into English: “There's certain terms and things that have certain meanings that don't translate into English. So there's, you know, there's, to me there's still a lot of important uses of it, and how it's used" (T-1).

Kakwa tsiltsil pointed out that Chinuk Wawa is structured differently than English and that implies meanings different from English. He highlighted the connection between the structure of Chinuk Wawa and a different worldview:

The way that we combine things in Chinuk. It has a different, it's a more of a NaIndian-, or Native American way of looking at the world. Like, for instance, a year is one winter. It's more [in] connection with the earth mother and sky father. (Kakwa tsiltsil)

Kakwa tsiltsil gave another example of this Native way of looking at things by describing the words for the cardinal directions, north and south. In Chinuk Wawa, the word for north, kikwali-tsaqw iwa [translation: down-river direction] and south, saxalitsaqw iwa [translation: up-river direction] have a direct and concrete relationship with the geography of the Pacific Northwest. The Willamette and Columbia Rivers flow north to the ocean; therefore, the downstream direction of the river corresponds to north and the upstream direction of the river corresponds to south. This direct correspondence of language to a geographic feature is not often found in English.

These participants each cited Chinuk Wawa as encoding language in a different way than English. All three participants were interested in the world that Chinuk Wawa symbolizes in contrast to the world symbolized by English. Kakwa tsiltsil talked about 
English as a "colonial language ... dominant ... it kind of sucks up ... different words as it goes." In contrast, he cited Chinuk Wawa as containing a great reverence for mother earth. The idea that language encodes a different worldview is the topic of the controversial Sapir-Whorf Hypothesis that states in its milder version that language “shapes" thought (Haynes, 2007, p. 77).

Connection to Pacific Northwest history through using Chinuk Wawa.

Four participants, two non-Native and two Native, saw Chinuk Wawa as the most appropriate language for talking about events or stories from the era when Chinuk Wawa was the lingua franca of the Pacific Northwest because they saw Chinuk Wawa as being able to uniquely convey the historical weight of that recounting. Participants considered Chinuk Wawa as crucial to accurately describing Pacific Northwest historical events and their impacts, from both Native and non-Native perspectives. Nettle posited that telling a story with historical significance is better told in the language in which the story happened in order to get across all the historical weight carried by the story. He reported that through translating the story, the feeling of the gravity of that moment is lost. T-1 spoke about a specific word in Chinuk Wawa that has connotations difficult to convey in English: “'ikanum' [translation: myth, legend] has a really important meaning, tribally and how it relates to the old stories and things like that. And how it's translated really doesn't clearly say what you're saying in Chinuk Wawa" (T-1). ShawashB discussed how historic trauma experienced by his Native American ancestors occurred when Chinuk Wawa was the language to communicate with non-Natives. For him, knowing Chinuk Wawa helped him to deal 
with his own relationship to that historic trauma. "Because my ancestors experienced that discrimination, I have some of that inside of me and have to deal with that" (ShawashB). He went on to say that keeping Chinuk Wawa alive connected him to that part of his past in a way that helped him deal with the trauma.

Billy stated that the Chinuk Wawa language was another way of looking at the world, and speaking it was a way of acknowledging the importance and meaning of the lives of up to 100,000 people who lived along the Columbia River and historically spoke it. He added that Chinuk Wawa was a way to get at how people of the past thought about things: "But I think there's something more at the gut that, getting in touch with the past, getting in touch with how people used to do things, and how people used to think about things" (Billy).

Participants reported that they were motivated to learn Chinuk Wawa because it allowed them to connect to and explore realms generally not available in the modern world. Chinuk Wawa served as a portal to connect participants to Native ancestors, Native culture, and Pacific Northwest history and worldviews.

\section{Connection to the Pacific Northwest region.}

Connection to the Pacific Northwest region.

Four non-tribally affiliated participants, Billy, Nettle, Kanim, and Keyskeys reported that one of their reasons for learning Chinuk Wawa was the feeling of connection to the Pacific Northwest region, their home, that speaking Chinuk Wawa gave them. I did not find a corollary theme in the literature. 
Billy viewed learning Chinuk Wawa as a way to learn about Pacific Northwest history: “There's so much knowledge and richness that comes with knowing Chinuk Wawa, knowing history, knowing what happened here and continues to happen here. To me that's important" (Billy). He went on to evaluate his experience of studying Chinuk Wawa as a "rich experience of discovering things about this area" the history of the place and of Native people. For Billy, knowing and speaking Chinuk Wawa was a marker of the depth of his connection to the Pacific Northwest and its history. Additionally, Billy stated that since Chinuk Wawa was one of the local languages, he wished that everyone living in the Pacific Northwest would learn Chinuk Wawa, simply because they lived here.

Nettle, an Oregonian, reported that one of his motivations to learn Chinuk Wawa was to connect him to the landscape, the ecology of this region. He reflected on how knowing Chinuk Wawa might have changed how he interacted with the northwestern Oregon river of his childhood:

I grew up on that river and, had I known [Chinuk Wawa] as a kid that might have changed my thought about how I interacted with the river. It certainly has since I learned it, but not in the way I thought it was going to. I thought it was going to be a much deeper experience, but it was still deep enough. That's really what's kept me interested has been, it really has connected me to the landscape. (Nettle)

Nettle also talked about the concept of 'when in Rome,' meaning that when you are in a particular place, you adopt the customs and language of that place out of 
respect for the inhabitants of that place. He stated: "I think it's rude not to speak the local language" (Nettle). Nettle reflected on other non-Native people's motivations to learn Chinuk Wawa. He questioned why they came to class:

'You have no connection to the tribe; you have no connection necessarily to the language.' But those other people also had this feeling of 'when in Rome'. And I honestly think that the people who-, maybe this gets down to the heart of this, I think that the people who are coming have this same when-in-Rome feeling. I think that's the thing that motivates most people is that, 'of course I should learn the local language. I live here.' And then I think some people take it to the next step, which is, I want a connection to the land. (Nettle)

He then named several non-Native people who harvested native plants for food, medicine, and basket-making materials as a way to embody a deeper connection to the land. Nettle shared a language goal that he had achieved in Chinuk Wawa: "alta nayka nanich saman uk sic hum khapa tsaqw." [Translation: now I see the salmon that swim in the river] (Nettle). He reported that being able to speak in Chinuk Wawa about the local landscape was a marker of his level of connection to it. He also reported that this ability to connect to the landscape motivated him to learn Chinuk Wawa.

By speaking Chinuk Wawa, Kanim connected to the Pacific Northwest in four ways: speaking locally, connecting to her value of staying rooted in one place, speaking a language that historically included Native and non-Native speakers, and connecting to myths she heard about the PNW during her childhood. One of her motivations was to 
extend the idea of the ethic of shopping and living locally to language and, specifically, Chinuk Wawa. To her, speaking Chinuk Wawa meant speaking locally: It means speaking in the language that connects to here. The language from here, I'm here. I was born here. I live here. I want to talk here. That's what it means to me, really. It means the language of this place. ukuk ili?i [translation: this place/this land]. (Kanim)

One of Kanim's core values was about being rooted in one place. She was born and raised in just one house in Portland, and she talked about being able to connect to the trees and the other neighborhood children because of that rootedness to one place. She is now living in the third house she has ever lived in. Kanim stated that she related to Chinuk Wawa as a language of this place and of cultures who were rooted to the region. Because Chinuk Wawa happens to be one of the languages of the Pacific Northwest that includes vocabulary and grammar from indigenous languages that were spoken in this area for at least 10,000 years, Kanim reported that speaking Chinuk Wawa connected her more deeply to this place.

For Kanim, the fact that Chinuk Wawa was a trade language, including both indigenous and colonial languages, makes it open and inclusive of Native and nonNative people of the Pacific Northwest region:

And this [Chinuk Wawa] is not only local in that it's based on Native people who lived here, but it's also a trade language so it was invented so different people with different languages could speak together, including European people. So to me that means it's open and welcomes people of other heritages. (Kanim) 
Additionally, for Kanim, a book from grade school planted a seed of desire in her to learn Chinuk Wawa. She had heard fairy tales about places in Europe, but when her teacher read a book about myths from the Pacific Northwest, Kanim was intrigued, "When I was in $4^{\text {th }}$ grade, the teacher read this book, Kutkos Chinook Tyee (Colbert, 1942) to us and it grabbed my imagination because it was mythic stories about the places I'd been." Reading myths about places she'd actually been like the Columbia River and the Pacific Ocean impacted her. Additionally, there were Chinuk Wawa words incorporated into the story, albeit with the non-Native dialect and orthographic representation, "But the language is in there. So I mean the language has sort of been in the background of my consciousness since then" (Kanim). Kanim spoke about the multiple ways that Chinuk Wawa intrigued her and kept her very interested in learning it as a way to connect to the Pacific Northwest.

Keyskeys talked about being generally interested in ancient civilizations, and since he was from Portland, Oregon, he focused on ancient civilizations of the Pacific Northwest:

And I really got drawn into anthropology through Wayne Suttles [late anthropologist and linguist at Portland State University] and I think even as a kid I kind of had a curiosity about ancient civilizations and what with having an Oregon childhood, I think I became intrigued by some of the Western Oregon people. (Keyskeys)

Keyskeys connected his childhood experiences of playing outdoors coupled with his interest in ancient civilizations to his desire to learn about Western Oregon Native 
people. In studying Anthropology with a focus on the Northwest Native people, he found a path to learn about those people.

Billy, Nettle, Kanim, and Keyskeys said they were motivated to learn and speak Chinuk Wawa because it strengthened their connections to the Pacific Northwest. The nature of those connections varied, from connecting to the history, to the landscape or to childhood experiences.

Connection with the earth.

Two non-Native participants, Kanim and Kakwa tsiltsil stated that learning Chinuk Wawa deepened and reflected their connection with the earth. This theme was not in the literature as such. Kanim responded to a question about what learning Chinuk Wawa has been like for her by saying:

It's been like coming home because to me ... someone [Roberta Connor, Director, Tamastslikt Cultural Institute] said that the indigenous languages are the ecosystems speaking, like they encode the relationship between people and the land. And I think that's true. And so this being a language that's based on languages from here, it feels like everything that I've always known is-, now I can suddenly understand their language. (Kanim)

In addition to deepening their connection to the earth, Kanim and Kakwa tsiltsil were motivated to learn and teach Chinuk Wawa because they sought to change the way that humans relate to the earth. They saw learning Chinuk Wawa as a way that people could connect with the earth and perhaps care more about and change the way they treat it. Kanim spoke about the Hanford nuclear waste site as a risk to human and 
environmental health. She stressed the importance of connecting to the land now rather than later:

And we're sitting on that same kind of powder keg upriver from us. Anyway, so it's vital that we learn to connect now, to the land, to the other beings on the land, to the people who have a long history with the land, and plus it's just vital as people knowing people that we should care. (Kanim)

Kanim reported that Chinuk Wawa helped her to connect to the earth because it helped her to read the landscape with different eyes. Kanim shared how learning Chinuk Wawa changed her ability to hear and speak to the land and local animals. "The connection to the beings here.... I just feel like I've become able to hear and speak in a new way, 'cause it's connected to this place" (Kanim). She considered her relationship to the earth, the land, and the local plants and animals as a core value in her life:

But to connect to place is important, because if we don't know who the tree is, it's much easier to cut the tree down. If we don't know how the water, how the river has been, and if we don't pay attention to how the river is now as opposed to how it was, how are we going to plan for how it's going to be in the future? And if we don't know how to find and eat the things that people knew how to do sustainably here in the past, how are we going to do it sustainably in the future? And the language connects to all of that. It helps us to connect to people who were connected here earlier. (Kanim)

Kakwa tsiltsil expressed his motivation as tied to connection to this place: "I fell in love with it. It's a beautiful language. It speaks of this land, so I fell in love with it" 
(Kakwa tsiltsil). For these two participants, Chinuk Wawa was a powerful vehicle to connect them to the earth.

Connection to participants' spirituality.

In the following discussion, I share all the participants' responses to the interview question posed about links between studying Chinuk Wawa and their own religious and/or spiritual beliefs. I designed this category based on my observations of the community. All eight participants stated that there was a connection between Chinuk Wawa and their spirituality. This connection varied greatly between participants, with some citing a direct link between Chinuk Wawa and their spirituality while others noted an indirect link. The nature of the connection also varied among participants, with spirituality meaning different things: connection to nature, a link to another religion, or a sense of the Chinuk Wawa communicating from the heart.

For two participants, Kanim and Nettle, their spirituality was connected to the land and, in so far as Chinuk Wawa deepened their connections to the land, they felt that choosing to learn it deepened their spirituality. Kanim was motivated to learn Chinuk Wawa because of what she understood to be the interconnecting features of her belief system - land, this language, and her spirituality including being part of an ancient earth-based tradition:

Chinuk Wawa connects to my spirituality because my spirituality is connected to the land. And the language is connected to the land. So if the language is connected to the land, and my spirituality is connected to the land, they really connect strongly. (Kanim) 
Nettle reported that he thought that learning Chinuk Wawa would help him to live in a more wild way, a way that God wanted humans to live. For him, connecting to the landscape more deeply by learning and speaking Chinuk Wawa was a spiritual experience:

Connecting to the landscape, I kind of had a funny thought about God. And that is that I don't think that humans were intended to live off of Safeway. I think we were intended to live more wild and so, having that connection to the land. (Nettle)

He had expected that Chinuk Wawa would be even more deeply connected to the landscape than he found it to be. However, as a trade language Chinuk Wawa is a hybrid language representing a hybrid culture of the Pacific Northwest in the 1700-1800s and as such, it did not meet his expectations for a Native language. He acknowledged that his expectations were stereotyping Native culture and were based on the romanticization of Native cultures. He suggested that if he spoke Mollalish, a Pacific Northwest indigenous language, now extinct, he might be an even better steward of his land, and, thus, make God happier.

Keyskeys noted that Chinuk Wawa did not relate to his religious or spiritual beliefs directly, if at all, but he talked about Chinuk Wawa as a minimal language. He said that speaking Chinuk Wawa made him question how many words people really actually need to communicate. He pointed to Grand Ronde elder, Wilson Bobb, who stated that Chinuk Wawa was better at expressing ideas in a genuine, heartfelt way. According to Keyskeys, Wilson Bobb believed that: 
Jargon is a more genuine language than English. ... He [Wilson Bobb] said he could remember the old days when he was young and that there were, some of the community leaders would get up and speak in Jargon. . . how sort of straight and sort of from the heart the language was. (Keyskeys)

Though Keyskeys did not explicitly state a spiritual or religious connection, he said that speaking a minimal language like Chinuk Wawa to express maximal thoughts was very satisfying when it was successful.

ShawashB used Chinuk Wawa as part of his religious activities. He saw it both as a personal connection for him as well as a historical reality where missionaries used Chinuk Wawa to teach about Catholicism:

I pray in Chinuk Wawa. I say large portions of the mass in Chinuk Wawa ... . I mean one of the reasons that a lot of Natives learned Chinuk Wawa was because missionaries were using it as a means to teach them about God. And so there's definitely that connection there. (ShawashB)

Four participants either answered vaguely or chose not to respond. T- 1 stated that he did feel a connection between speaking Chinuk Wawa and his spirituality/religious beliefs but chose not to speak about it during the interview. I knew this participant less than the other participants I interviewed; and he may not have been comfortable sharing such information with me.

Charley Horse, a Native participant, responded to the question by saying that she did not know exactly what the link was but that by speaking Chinuk Wawa, she was 
able to relate to her tribe in a more meaningful way and that the language was something of value that she could bring to and give back to her tribe.

Kakwa tsiltsil responded by stating that there was a link between parts of his spirituality and learning and speaking Chinuk Wawa but he did not think he could describe it nor was he sure he wanted to describe it to me.

One of the most subtle spiritual connections was the case of Billy, where he did not know if there was a spiritual connection for him, but he reported his sense that warmth existed between Franz Boas, an ethnographer, and Charles Cultee, a Lower Chinook informant. Billy saw a spiritual element in that warmness. As a linguist, these historical figures, Boas and Cultee, held a lot of meaning for Billy.

For some participants, there was a clear and motivating link between learning and speaking Chinuk Wawa and their spirituality. For others, though they were not able or did not want to articulate a clear link between speaking Chinuk Wawa and their spirituality, they indicated that such a link existed, and their descriptions indicate that this link was positive for them, and I would conclude, a motivating factor in their Chinuk Wawa studies.

This theme lay at an intersection between language and culture. For participants, Chinuk Wawa was a portal or an entry point into another worldview and culture. Participants were able to gain access PNW Native cultures through Chinuk Wawa. 


\section{Theme 2: Preservation, maintenance and revitalization of historical knowledge/Chinuk Wawa/Pacific Northwest Native culture.}

While the theme of Connection was about an individual's personal connection to Pacific Northwest history, Native American ancestors, and this place, the Preservation theme describes motivations to actively preserve, maintain and revitalize Chinuk Wawa for current and future generations of speakers. Participants cited the desire to preserve Chinuk Wawa, its history, and its ties to Native culture as part of their motivation for being involved in the Chinuk Wawa language community.

\section{Preserving Chinuk Wawa.}

Preserve Chinuk Wawa because it is an endangered language.

Three participants reported that they wanted to preserve Chinuk Wawa because it is an endangered language, and they did not want to see it disappear. Nettle, a nonNative participant, was actively involved in an experiment to preserve and revitalize Chinuk Wawa as well as other endangered languages through using a language teaching method called 'Where are your Keys' (p. 17-18). “That was the initial impetus for the entire experiment was languages are dying, we're under a time crunch, how fast can we do this?" (Nettle). He was concerned not only with revitalizing Chinuk Wawa. His scope was broader in that he was working to revitalize all endangered languages.

T-1, a Native participant, responded to the question about what kept him coming back to Chinuk Wawa by saying: 'Cause it's one of our tribal languages and [I] want to see it keep going" (T-1). He did not want to see the language go extinct because it was one of his tribal languages. His job at CTGR included revitalizing many aspects of his tribal culture through teaching various skills and traditional knowledge to Portland 
CTGR tribal members. These skills included making traditional crafts out of native plant materials when possible, wood carving, and speaking Chinuk Wawa. Revitalizing Chinuk Wawa was one manifestation of his overall goal of revitalizing CTGR tribal traditions.

As noted in Chapter One, there are about 30 semi-fluent to fluent Chinuk Wawa speakers in the Portland, Eugene, and Grand Ronde communities. Compared to the 100,000 speakers in the 1880 's, the contemporary community is very small. Kakwa tsiltsil, a non-Native participant, discussed that lack of speakers as motivating him to continue to come to classes:

I saw it [Chinuk Wawa] was becoming extinct. It needed help, spirit asked me to help, hold onto it till the tribe took it back.... And I wanted to hold onto it until it was taken back. 'Cause nobody was speaking it. Scary really. (Kakwa tsiltsil) Kakwa tsiltsil talked about feeling sad and lonely in this language. Part of his motivation to continue coming to classes is that he does not have other places to speak the language. "What a lonely, I mean you can't talk to yourself, really. That's not a living language" (Kakwa tsiltsil). He spoke about being a vessel for Chinuk Wawa until others were ready to take it on. Simply by speaking Chinuk Wawa, he saw himself as someone who could serve the language by keeping it alive. He also saw Chinuk Wawa as a valuable language worth preserving simply as a piece of the human fabric that is as valuable and unique as plants and animals: "To have it not be accessible to humans would be a real waste" (Kakwa tsiltsil). This reason was cited in Saving Languages as 
one of the common reasons communities decide to preserve their endangered language (Grenoble \& Whaley, 2006, p. 20).

All three participants, Nettle, T-1, and Kakwa tsiltsil, saw Chinuk Wawa preservation as important but for different reasons: as a test case for refining a teaching method to save many endangered languages, to keep a tribal language alive and pass it on, and as a unique and valuable part of the human experience.

Preserve Chinuk Wawa for future generations.

Three participants, T-1, ShawashB, and Kakwa tsiltsil, focused on the need to preserve Chinuk Wawa so that it would be available for future generations to speak as a living language as well give them a means to connect to the Native cultures of the CTGR tribe. In response to my asking whether there had been any change or shift in motivation since starting to study Chinuk Wawa, T-1 responded:

Not really, probably more the thing is just working with others to teach it, or to learn it. So that's the main thing is just trying to have people in contact with it, so they develop an interest too and want to keep it going and want to develop their skills, their language skills, keep passing it along. (T-1)

T-1 was motivated to teach Chinuk Wawa to others so that they would pass it on to future generations.

ShawashB saw the value of saving Chinuk Wawa because it might preserve traditional Native American knowledge useful for contemporary society:

Somewhere down in the rainforest or somewhere in Africa, there is a language which has somewhere in its language a cure for cancer and we haven't yet 
figured that out yet. But when that language dies, and we find out, oh this guy found a cure for cancer, it's called the whatever bush, oh, well no one speaks that language so we don't know what they're talking about. Then that is gone. Native Americans did a lot of things in traditional ways which we could use to better our society. (ShawashB)

ShawashB touched on the fact that the language may hold knowledge that has not been accessed in a contemporary time. He discussed the idea that Chinuk Wawa and other endangered languages are important to preserve for potential use in the future.

Kakwa tsiltsil, a non-Native participant, talked about speaking Chinuk Wawa until he was 100 years old in order to ensure that the language would continue to be spoken. That was his level of dedication to passing this language to the next generation. He would prefer that CTGR tribal members take ownership of Chinuk Wawa by learning and speaking Chinuk Wawa:

And like I said, I felt at this time, back, that spirit asked me to take this on in my body until it could go back in a physical form. It will talk again in some tribal member's voice. And it's not at that point now, so I'll keep speaking it. I think until ShawashB and I are 100, we'll keep speaking it. (Kakwa tsiltsil) $\mathrm{T}-1$, ShawashB, and Kakwa tsiltsil wanted to ensure that this language and the knowledge, values, and lifestyle associated with it would be transferred to future generations of people.

Expanding the area where Chinuk Wawa is currently spoken to reflect historical norms. 
Two Native participants reported they were motivated to revitalize Chinuk Wawa to reflect the regions and numbers of speakers of the late 1800s: "I think it's a really good thing for us to expand Chinuk Wawa into areas where Chinuk Wawa was traditionally spoken" (ShawashB). T-1 shared a similar motivation:

Pretty much just like today. It would be my tribal community. And start the other tribes that we interact with and stuff like that, 'cause most of the tribes along the Columbia River and along the coast and in the valley, all of our tribes have pretty much spoke it, so pretty much just within our tribal community membership and intertribal relations that we have. (T-1)

Both of these participants were CTGR tribal members, and their perspective reflected their similar desires to strengthen the cultural and language bonds within their tribe as well as between other Pacific Northwest tribes, based on a historically intact model of their culture.

Efforts to preserve Chinuk Wawa.

Participants talked about specific ways that they felt compelled to contribute to the Chinuk Wawa revitalization effort. This sub-category was not in the literature as such. One Native participant said:

I'm really into keeping it alive and teaching it. . . I do a lot of things to help ensure that that happens. I mean all the classes I teach, the pamphlet I'm trying to make, the website I manage. They're all there to help ensure that this language survives. So that's really the goal here. (ShawashB) 
ShawashB's motivation was apparent in the multiple ways he was actively working to preserve Chinuk Wawa.

Keyskeys had been actively involved in the Chinuk Wawa language

revitalization effort at CTGR for about 34 years with some interim breaks and reported that his efforts were tied to there being people willing to learn Chinuk Wawa: "If other people are interested in keeping it going, and I can contribute to that, then that gives me some satisfaction" (Keyskeys). This sense of satisfaction in teaching people interested in learning and/or preserving Chinuk Wawa motivated Keyskeys. He had taught Chinuk Wawa through LCC since 2007, and he had always been concerned that if there were not sufficient students, the classes would end. Additionally, he was actively involved in various documentation and archiving projects as well as creating a Chinuk Wawa dictionary based on how it was historically spoken by the CTGR Grand Ronde elders.

Kakwa tsiltsil, a non-Native participant, was very passionate about preserving Chinuk Wawa. He had been involved with learning and teaching Chinuk Wawa for two and a half years. He brought up an important point about being a part of such a small group of people: every person counts. And there's no certainty that a language will survive, even with all of the efforts made by people over the years. He reported his motivations for learning Chinuk Wawa:

It's [learning Chinuk Wawa] been great. I haven't been able to put it down. Part of it too is that I probably would have put it down if there were more people. There's just not enough people speaking it. ShawashB, we're going to talk 
Chinook Jargon until we pass on. He wants to live to be 100, so I'm like, okay, I'll live to be 100. But me and him'll talk Chinuk, right? (Kakwa tsiltsil) Kakwa tsiltsil's reported effort was simply a commitment to continue speaking it with another member of the language community. He saw the longevity of commitment as important for the preservation of Chinuk Wawa.

Keyskeys and T-1 specified the ways in which they contributed to the preservation of Chinuk Wawa by speaking Chinuk Wawa even when speaking English would be easier. Their efforts showed their level of commitment to preserving Chinuk Wawa. "I make a deliberate effort to talk it there [Grand Ronde immersion preschool] just to be giving the kids language and to try to encourage the teachers to use more Chinuk Wawa" (Keyskeys). T-1 reported his efforts to teach his family, other tribal members and other interested tribes Chinuk Wawa:

With some of my family, like the kids, the younger kids, nieces and nephews, stuff like that. I try to use it with them. And any time I'm with any tribal people that know the language or are interested in it, things like that. Other tribes that are interested, so and have connections to the language. (T-1) Specific efforts to preserve Chinuk Wawa included: actively teaching, a long-term commitment to speak the language, and speaking Chinuk Wawa in domains where English is the expected and default language.

Preserving Chinuk Wawa for the Grand Ronde Tribal community.

Kakwa tsiltsil, a non-Native participant, had a specific demographic in mind when he talked about his motivation to preserve Chinuk Wawa: "I really want to see 
that again. I want to see, that is my prayer is that every single tribal member speaks Chinuk Wawa again" (Kakwa tsiltsil). Most Grand Ronde tribal families spoke Chinuk Wawa in the late 1800s and early 1900s so CTGR descendants have historical and familial ties to Chinuk Wawa. His motivation to teach this demographic was clear in his concern regarding the current state of Grand Ronde tribal members speaking Chinuk Wawa:

It's kind of the young people that know the Wawa, but there really isn't a lot being spoken ... . It's funny talking to the little kids, 'cause they know it ... . There's this gap, I wish that there was more talking in the home. It just doesn't seem to take off. (Kakwa tsiltsil)

His goal in Chinuk Wawa revitalization was to support any tribal member who wanted to learn the language. Regarding the community class held in a private residence: "But I wasn't so much interested in working with other baston tilixam [translation: white people]. I think it's important and great, but I really wanted to stick with the Grand Ronde, 'cause there were just so few" (Kakwa tsiltsil). His original and primary motivation revolved around teaching CTGR members Chinuk Wawa: “It's still to help more Grand Ronde tilixam chaku-kəmtəks chinuk wawa [translation: Grand Ronde people learn Chinuk Wawa]. I want more Grand Ronde tribal members to learn Chinook Jargon" (Kakwa tsiltsil). For Kakwa tsiltsil, teaching CTGR tribal members was an important aspect of his motivation and involvement in the Chinuk Wawa language community. He spoke the language in order to preserve it so that it would be spoken by more CTGR tribal members. 
Supporting relationships as a motivating factor.

Billy and Kakwa tsiltsil, two non-Native participants, discussed their participation in terms of supporting Chinuk Wawa revitalization without directing or leading it. This motivation was not reported in the literature. Billy expressed a sense of being a steward of the language and creating a role or space that could be taken over by someone else further down the road, while not taking control and making ultimate decisions about the language programs or classes. Billy stated: "I just sort of feel welcome and happy to be welcomed into that community and wherever it goes is where it goes. And I definitely don't want to be the one to determine too much of it" (Billy). He saw his role as a supporter rather than as someone determining the direction of Chinuk Wawa revitalization:

I'm a good person for the community, and why the Chinuk Wawa community is good for me is that the Chinuk Wawa community wants speakers and it doesn't care what your cultural heritage is. I mean it cares but it doesn't exclude you from it. So I'm probably not the right person to make executive decisions about language, but I'm an important person to come in and provide energy and a warm body in a chair that makes interesting conversation. And what the community's about is talking. So I can participate in that and I'm welcomed, and I feel like what I contribute is valuable. And I feel like other people value what I contribute. (Billy)

This stance of being a supporter of other's leadership may be emphasized in this and other language revitalization communities where historical hegemonies and 
current policies of self-determination among Native communities make power roles an especially salient and sensitive issue. Based on interview transcripts, non-Native people were more openly concerned about being sensitive to the needs of the Native community than the Native American participants. Natives and non-Natives were working together on the Chinuk Wawa preservation, and this non-Native participant was very aware of how he navigated within the community.

Kakwa tsiltsil similarly saw his role as supporting a Native participant, ShawashB, in his teaching duties as a way to effectively support Chinuk Wawa preservation without being a leader or decision maker: "I really like to show up for ShawashB at the Wednesday tribal" (Kakwa tsiltsil). Kakwa tsiltsil was highly motivated to support this teacher because he wanted to see Chinuk Wawa continue: Sometimes I feel like, if I could be there to talk to him [ShawashB], keep him going. ... 'God, let's support this guy, so that we can keep it going.' 'Cause that's the perfect, I can't think of a better word, a perfect scenario is a tribal, a Grand Ronde tribal member. (Kakwa tsiltsil) He reported that he needed to continue to come to Chinuk Wawa classes not only for himself but also because there were so few people coming. Both Billy and Kakwa tsiltsil were committed to preserving Chinuk Wawa and both had found avenues for doing that without taking on authoritative leadership roles within the community. They purposefully supported Native participants and language planners in using the power of determination to make decisions regarding language use. 


\section{Chinuk Wawa preservation as a gateway to other Pacific Northwest Native languages and CTGR tribal languages.}

Since Chinuk Wawa was a contact language, it includes words from several Northwest tribes as discussed in the literature review. Not surprisingly then, for people with connections or interests in Pacific Northwest Native languages, Chinuk Wawa provides a connection to those languages. When asked what keeps T-1 coming back to Chinuk Wawa, he stated:

'Cause it's one of our tribal languages and [I] want to see it keep going, and then like I mentioned, it's just kind of a gateway to the older languages so, hopefully, we can have maybe not the whole, parts of the languages restored and used. Right now we used a lot of baston [translation: English] and the French in there, maybe we can change and use some more of the older languages, incorporate into the Chinuk Wawa. Things like that. (T-1)

His interest in preserving his ancestral languages also extended to other CTGR tribal languages. Additionally, he reported the desire to add words from other Native languages back into Chinuk Wawa. I suspect the reason for this 'language purification' was to make Chinuk Wawa more 'Native'. This was a goal of some of the other participants as well, both Native and non-Native.

Charley Horse was interested in learning Chinuk Wawa as a bridge to learning another Pacific Northwest Native language associated with her tribe. She discussed the belief by other members of her tribe that their language was too difficult to pronounce and thus too difficult to learn. She pointed out that Chinuk Wawa is "exactly the same. . .. same alphabet.... all the sounds that are there in Chinuk are also the same sounds 
that are in" her tribal language (Charley Horse). Therefore, if she could teach her tribe the Chinuk Wawa alphabet, they would know all of the sounds of the tribal language, and perhaps some people might learn that language as well.

Both T-1 and Charley Horse were motivated by the opportunity to learn more about other languages represented in Chinuk Wawa by some sounds as well as in the vocabulary and grammar.

\section{Preserving Chinuk Wawa as a way to honor and respect Elders.}

T-1 shared his vision for Chinuk Wawa and its community of speakers by citing recognition and honor for his Native elders as an important motivation for him:

Course we have few speakers today, and we've lost a lot of our elders that spoke. So hopefully that we can just continue to build the number of speakers that we have that are actively speaking and using it, and they understand its importance, and they do it in a way that recognizes and honors our elders, I guess. (T-1)

He felt that by speaking Chinuk Wawa, one of the languages spoken by his grandparents and elders, he was recognizing and respecting them. He also spoke about how he felt it important that all Chinuk Wawa speakers learn and speak Chinuk Wawa in a way that continues to carry and include a recognition and respect for the origins of the language and the previous speakers.

It's kind of like an honor, 'cause not a lot of people speak it these days. And I think it's just kind of out of respect and a recognition of them to speak it today, to keep it going. (T-1) 
Part of his motivation for preserving Chinuk Wawa was to respect and honor his elders. And he reported that speaking Chinuk Wawa was an honor and a privilege for him because it was a gesture of respect for his elders.

\section{Preserving Chinuk Wawa as a nexus for preserving important connections.}

Kanim saw Chinuk Wawa as serving as a nexus for connecting many different elements: people, history, the future, and this place. These connections were important to her and in preserving Chinuk Wawa she felt she was contributing to preserving these connections:

So I had the experience of being an outsider with I was in high school; so, to me things like keeping a language alive in a community is important too.... Because it creates, it preserves the interconnection between generations and between history and today and the future and the people and the place ... it preserves those connections. And allows people who aren't yet connected to connect, which is why I think it's so important for the future. (Kanim)

The Chinuk Wawa language and the language community served as a container to hold all of these intertwined aspects: people, history, place, the future. By preserving Chinuk Wawa, Kanim felt that the possibility of making these connections would be preserved.

\section{Theme 3: Relationships between people/people belonging to a community.}

This theme concerns how relationships between people motivated participants' involvement with the Chinuk Wawa language community, "the community" being idiosyncratically defined by each participant. This theme was not reported in the literature. Relationships affected some participants' motivations to both begin to be 
involved with Chinuk Wawa; in addition, many participants cited that the relationships they developed in the Chinuk Wawa language community were a strong motivating factor to continue.

\section{Relationships as motivating participants to come to classes initially.}

One member cited going along with family members as the primary reason for first coming to Chinuk Wawa class.

I'm going to be honest. Nine years ago I showed up because of a class. I don't think I was actually showing up because of Chinuk Wawa. I think I was showing up because members of my family were going. (ShawashB)

Later in the interview, he reiterated his family as being his initial motivation. He talked about how his motivation had changed. "In the beginning it was just something to do. Something that some of the family were doing, and now it's kind of like, I'm really into keeping it alive and teaching it" (ShawashB). He now knows the language better than those members of his family who initially motivated him to come to class.

Kanim had wanted to learn Chinuk Wawa after reading a book with some Chinuk Wawa words in the $4^{\text {th }}$ grade. However, she felt better coming to a Chinuk Wawa class after she was invited by a Native friend who was already involved in the classes: When a Native friend already learning Chinuk Wawa [real name omitted] said,' well come and learn.' I've always felt like I really want to. And I really should. And you know, so maybe I will. And it also helps that I knew someone who was learning. I don't think I would have been brave enough to just seek it out on my own without somebody inviting me. (Kanim) 
For ShawashB and Kanim, getting into the door of the CTGR Portland tribal office was a major hurdle to their being committed members of the Chinuk Wawa language community. Strong relationships with people already coming to classes were crucial initial motivators for both this CTGR tribally-affiliated Native and this non-triballyaffiliated Native participant to learn Chinuk Wawa.

\section{Relationships as motivating participants to continue learning Chinuk Wawa.} Another participant stated that relationships that he had built through coming to Chinuk Wawa classes were an important part of his staying involved. When asked what keeps him coming back to classes, he said, "It's almost like a habit. You get attached to something, you get to know people" (Billy). He went on to say:

I've done it long enough now that those people are my friends and if it's important to them it's important to me. So, even though I don't identify myself as necessarily part of that community, that involvement I think is ... keeps me coming back, or keeps me involved. (Billy)

Billy articulated a perspective and a sense of community that others may have felt though did not express. After connecting to people within the community, Billy was motivated to continue to come to classes to see people he had gotten to know through learning Chinuk Wawa.

\section{Acceptance in a community as a motivating factor.}

For one participant, she believed that learning Chinuk Wawa to a certain level of proficiency would lead to her have greater acceptance within her tribal community as a teacher. She stated that she was already accepted as a member of her tribe in many 
different ways outside of her involvement with Chinuk Wawa. The tribal community she spoke of was a different one than the Portland Chinuk Wawa language community: If I'm going to be accepted in my community I have to ... have a level of competency with Chinuk Wawa if I'm going to be accepted, trusted ... be respected in my tribe as someone who can teach the language. Then I need to continue to increase my level of competency. (Charley Horse) She wanted to teach her tribe Chinuk Wawa in order to strengthen their tribal identity as well as give the tribe more political clout to become federally-recognized. Therefore, this motivation, acceptance in her tribal community as a Chinuk Wawa language teacher, was a step leading to her ultimate goals. She was the only participant to explicitly cite acceptance into a specific community as a motivating factor.

\section{Learning Chinuk Wawa because of involvement with tribal community.}

In response to the question about changes in his life since he began to learn Chinuk Wawa, T-1, a Native American participant stated: "Not really because it's, I'm pretty involved with the tribal community and stuff and so, to me it's just part of the tribal community.... It's tied to the community" (T-1). He learned Chinuk Wawa because of his involvement with the tribal community.

Keyskeys, a non-Native participant, was doing a research project about Chinuk Wawa use at the CTGR reservation. He did not intend to learn Chinuk Wawa, but eventually did as a by-product of his research. Relationships he forged during the research process lead to his learning Chinuk Wawa: "Eula Petite ${ }^{4}$ and her husband John

\footnotetext{
${ }^{4}$ A CTGR tribal member who taught Chinuk Wawa in Grand Ronde, OR in the early 1980s.
} 
sort of adopted me. So that's really, you know, that was my, that was always my strong connection, you know, my original strong connection to Grand Ronde” (Keyskeys).

Overall, six of the eight participants cited different types of relationships as being important to their motivation to learn Chinuk Wawa. With a larger participant group, and with a different, more anonymous methodology, a deeper analysis of how relationships affect motivation within a language community would be an interesting and perhaps, revealing study, inherently interdisciplinary in nature.

Theme 4: Instrumental motivation - learning Chinuk Wawa as a means to achieve a specific, concrete goal.

Instrumental motivation was minimal for most learners likely because Chinuk Wawa does not have a high status in the economic world. However, a few participants did report having an instrumental component to their motivation to learn Chinuk Wawa because they were paid to document and teach this language. Being involved in Chinuk Wawa revitalization served them in their academic and professional pursuits. Instrumental motivation has been extensively studied in the field of second language acquisition by Gardner and Lambert (1972), and Dörnyei (2009) as discussed in the literature review in Chapter Two.

As noted in the following discussion, four of the participants strongly embodied an instrumental motivation for learning Chinuk Wawa, while for the other four this was only a minimal motivation. None of participants expressed an interest in learning Chinuk Wawa solely on the basis of the tangible results they gained. 


\section{Using Chinuk Wawa for career/profession/making a living as a teacher/linguist.}

Six participants used Chinuk Wawa to further their professional pursuits. Each participant did so in unique ways. Five participants (ShawashB, Keyskeys, T-1, Billy, and Nettle) were able to supplement their income through Chinuk Wawa. No one was able to make enough money through Chinuk Wawa to fully support himself.

ShawashB, a Native participant, was in the process of looking for a job. He said about Chinuk Wawa:

I spend a good portion of my week teaching Chinuk Wawa, which is good. It definitely gives me something to do. While the job market is bad, I have something to occupy my time. I'd still be doing this even if I had a job, but if I had a job, I would be looking for ways to integrate this into my job. (ShawashB)

He went on to state that teaching Chinuk Wawa gave him professional teaching experience that he could put on his resume as well as a sense of purpose: "It gives me a sense of focus and a sense of purpose. It gives me something else to put on a resume" (ShawashB).

T-1 conducted cultural classes at the CTGR Portland tribal office and had previously worked for the CTGR tribes in Grand Ronde. He had other work outside of his job with the tribe.

Billy, a non-Native, had done a variety of linguistic and teaching jobs for the CTGR tribes, Lane Community College, and NAYA. Working for Chinuk Wawa revitalization dovetailed with his professional and linguistic interests in pidgin and creole languages and his ambitions to be a linguist. 
Keyskeys, a non-Native, responded to my asking what keeps him coming back by saying: "Oh, it's ended up being my job" (Keyskeys). Later in the interview, he stated: I had had the thought at one time when I was more academically-oriented of being a pidgin/creole linguist with a focus in Chinuk Wawa, but I got much farther being a teacher of Chinuk Wawa and a linguistic consultant in the context of a tribal language program. (Keyskeys)

Nettle, a non-Native, was a teacher and class organizer, funded by CTGR. He felt compelled to take on a teaching role because he was confident as a teacher and he knew Chinuk Wawa. However, he did not have another stable source of income, and he expressed frustration because of losing money and accruing debt. He acknowledged that the economic crisis of 2008 affected his Chinuk Wawa income negatively. By the end of this study, Nettle was no longer involved in teaching Chinuk Wawa partly because of the financial difficulties he faced.

For some participants, being professionally involved in revitalizing Chinuk Wawa led to a continual struggle for sufficient and consistent financial resources including money on which to live. People who committed to teaching classes or large projects necessarily sacrificed opportunities for other jobs or jobs with schedules that conflicted. Additionally, there was little guarantee of consistent, long-term work, at least within the Portland Chinuk Wawa language community. Since CTGR in Grand Ronde was the primary source of funding, relationships with people there was crucial. Additionally, leadership in Grand Ronde affected how much Chinuk Wawa revitalization was prioritized. People who committed to working on Chinuk Wawa 
revitalization often made financial sacrifices. Nettle spoke about this topic more than other participants, perhaps because he was more dependent on that income. The other four participants who benefited financially were not primarily dependent on this income for their support.

For the sixth participant in this category, Kanim, learning Chinuk Wawa affected her indirectly, through its impact on her professional career. She stated: "And it connects to my professional interests too, in how to do we reconnect with Earth? It's really my question that I'm working on, lifetime I guess. So, to me, the indigenous languages are a part of that" (Kanim). She did not work for any part of Chinuk Wawa revitalization efforts, but she still benefited professionally from knowing Chinuk Wawa.

\section{Using Chinuk Wawa as a political tool.}

Charley Horse, a Native American participant, cited that her goal in learning Chinuk Wawa was to teach her tribe this language in order to increase her tribe's chances for official recognition by the U.S. Federal Government. She stated:

If you have a certain number of speakers, then it enables, it strengthens your options to be recognized and to be funded. And we've been waiting a long time for that... They want to know how many language speakers there are in the tribe, always. It's a very important element for being taken seriously. It gives any tribe clout and credibility with the government, with powers that be. (Charley Horse)

Charley Horse saw learning Chinuk Wawa as an important part of the gaining political power and access to resources as a tribal entity. 
ShawashB envisioned his tribe using Chinuk Wawa as the language to interact with the outside world. Since Native American tribes are sovereign nations, they could potentially use a Native language as the primary means of communication with other governmental or tribal entities. ShawashB saw using Chinuk Wawa as a potential extension of historical interactions between sovereign nations and the U.S. government. He stated:

And we're still trying to determine how Native American tribes are going to interact with the outside world, tribal sovereignty. And I think this language works very well with that tribal sovereignty. This is how we have been interacting with the outside world for 200 years. This is how we are going to continue to do that. (ShawashB)

Charley Horse and ShawashB both saw the potential of using the Chinuk Wawa language for political purposes and as a means to tribal status in the non-Native world.

Using Chinuk Wawa to fulfill academic requirements.

Keyskeys and Billy reported that their initial reasons for learning Chinuk Wawa were tied to fulfilling academic requirements. Keyskeys studied the Grand Ronde Chinuk Wawa community in the early 1980's for his PhD dissertation: “I started studying it because, started a project of recording it, trying to find other speakers and recording them" (Keyskeys).

Billy studied Chinuk Wawa for a linguistics class where he had to choose an endangered language to research for a class project. Instead of choosing African languages, his initial motivation for taking the class, he decided to study Chinuk Wawa: 
"It seemed more reasonable to study a language that was around here rather than 10,000 miles away" (Billy).

This relates to the category where participants were motivated to learn Chinuk Wawa because it was locally available. For Billy and Keyskeys, the need to fulfill academic requirements coupled with the availability of Chinuk Wawa, influenced their choice to learn and use Chinuk Wawa.

\section{Using Chinuk Wawa as a test case for a unique language teaching method.}

Nettle, a non-Native participant, used Chinuk Wawa as a test case to develop and refine a method of revitalizing endangered languages through teaching (see pp. 1718). He had developed a specific method of language teaching in order to efficiently revitalize endangered languages, and Chinuk Wawa was the language with which he first tried this method. He reported that the fact that he first tested his teaching method using Chinuk Wawa was because when he asked the CTGR if he could try out his method on Chinuk Wawa, they agreed:

I was like, 'Hey, I’ve got a trick, and I know it will work, and you guys need, Indian Country needs to create teachers. And I've developed a system that will create teachers. You guys want it? No? You guys want it? Yes.' They just happened to be the people who said yes first. Really, that's the only reason that I speak Chinuk Wawa to this day. They said yes first. And so I guess that's pretty important for my motivation for learning Chinuk Wawa. (Nettle)

Chinuk Wawa, and the community trying to revitalize it, served this participant as a test scenario. He was not initially specifically interested in studying Chinuk Wawa. He 
was interested in Chinuk Wawa to the extent that it was an endangered Native American language with a community interested in revitalizing it.

\section{Chinuk Wawa as a local language available for study and involvement.}

The two self-identified linguists both fell into Chinuk Wawa because it was

locally available to study. Billy cited the locality of Chinuk Wawa as part of his motivation to study it:

I don't want to study bushmen when I'm living in America, because I'm actually in Portland studying this language from here, it has a realness to it. There's so many more opportunities to do real research and just be active and involved that I didn't have before, it was just linguistics out of a book, languages out of books or whatever. Even though this is a lot of language out of books, there's something more alive about it. (Billy)

Similarly, Keyskeys cited the availability of Chinuk Wawa as being a primary reason for studying it. He stated: "I just started falling into Chinuk Wawa because it was there" (Keyskeys). Additionally, he said: "I was doing this as a graduate student, and I was looking for a project" (Keyskeys). Many languages would have met his requirements for study, but because Chinuk Wawa was local, with a local community, he chose it as the object of his study. Since both Keyskeys and Billy lived in Portland and were interested in studying a local language, Chinuk Wawa represented an appropriate choice. 


\section{Learning Chinuk Wawa to gain access to people/community.}

This motivation overlaps with the theme of relationships and category of belonging to a community as a source of motivation. I did not find this theme cited in the literature. Kakwa tsiltsil, while trying to find local Native Americans interested in working with native plants in traditional ways, discovered Chinuk Wawa class offerings listed on the CTGR website. When Kakwa tsiltsil came to class for the first time, the non-Native teacher advised him to learn Chinuk Wawa. He decided to learn Chinuk Wawa in hopes that tribal members would be more receptive to him and that through this relationship with CTGR members, he would be able to expand the territory of camas, a native plant:

And it's true really what Nettle says that first time that I came in is that the more that I have learned the language, the more that they do take me more seriously. 'Cause I am not a tribal member. (Kakwa tsiltsil)

This participant has been a committed learner and teacher of Chinuk Wawa since that time. He has dedicated himself to the CTGR Chinuk Wawa community. His motivations to learn Chinuk Wawa for saving native plants shifted to include a belief that saving the language as a goal in and of itself was worthy of his time and commitment. He continued to work on saving the plants as well. Kakwa tsiltsil was the only participant in this study who offered this type of motivation.

\section{Theme 5: Affective motivation.}

This theme overlapped with others in that beneath the affective motivation there was generally another type of motivation as well. This theme emerged because 
participants did not always articulate why they were interested in being involved in Chinuk Wawa. Sometimes their reasons included a feeling or emotion. In the interviews, there were two types of Affective Motivation. One type was a general feeling of like or love or interest in the language, just for the sake of the language. The other type was one of moral responsibility or a "sense of crusade" to save Chinuk Wawa, as a dying language.

\section{Affective motivation as an interest in/like/love of the language itself.}

This category expressed the sentiments of four non-Native participants about

the language being beautiful and interesting and that they simply liked it or fell in love with it. During the interviews, while participants were articulating their reasons for their involvement with Chinuk Wawa, they would switch to saying they just liked it or some variation on that. Their motivations seemed to be based on an emotional response.

Keyskeys expressed his affective orientation to Chinuk Wawa by saying, "And I like Chinuk Wawa. It's really interesting, just speaking it, it requires you to be creative of course" (Keyskeys).

Kanim stated her emotional motivation in the following way: “It's just, I just really like it. I like the language. I like how it feels, how it sounds. It feels like home, it feels like almost like a mother tongue because the land is also our mother" (Kanim). Kanim went on to say: "It's in my mind. It's in my heart. I can't not speak it" (Kanim). When asked why she was still involved and interested in Chinuk Wawa, Kanim replied: "Oh well, once you fall in love with the language, you just want to talk it all the time" 
(Kanim). Though she expressed other more explicit and articulate motivations, her affective motivation was also a part of the full picture of Kanim's motivations to learn Chinuk Wawa.

Kakwa tsiltsil also talked about his love for Chinuk Wawa in terms of his feelings for it: “But I loved it. I spent a lot, I don't know why, I was just, loved it, and it loved me and I think it's a beautiful language" (Kakwa tsiltsil). Kakwa tsiltsil spoke in Chinuk Wawa to express how Chinuk Wawa affected him:

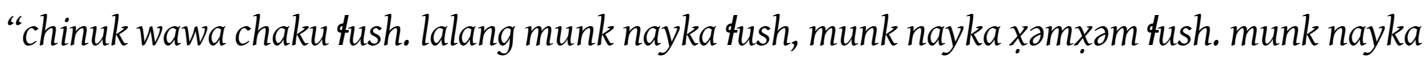
tomtəm dret \&ush. [Translation: Chinuk Wawa is good. The language makes me feel good. It makes my brain and my heart very good]" (Kakwa tsiltsil).

Billy, a non-Native participant, self-identified as a linguist, was discussing characteristics of Chinuk Wawa and then went on to convey his basic interest in languages as well as his interest in Chinuk Wawa:

I really like languages. There's something compelling about it. And I don't really know how to voice that other than it's extremely compelling. It's a funny language because it's a pidgin and it's simplified in a lot of ways, but it's complex in a lot of ways.... A lot of pidgins and creoles happened quickly, and my impression of Chinuk Wawa is that it has evolved over a much longer period. Or has had sudden changes that have happened over bigger spans of time. I don't know. It's just interesting. It's just a very interesting and compelling language. (Billy) 
He spoke about writing in Chinuk Wawa simply because it was fun: "I mean, I write for my own sake. I translate stuff and I write things, just because it's fun. It's a place to explore language" (Billy). His last comment on Chinuk Wawa expressed his affective motivation again: “I guess I keep doing Chinuk Wawa because I'm compelled by it. And it's a beautiful thing and all that" (Billy, p. 10).

Affective motivation, though often related to a deeper, underlying motivation, was also important in and of itself. It is related to intrinsic motivation where motivation stems from an internal sense of reward or enjoyment through doing an activity as discussed in the literature review by Csikszentmihalyi and Nahamura (1989). This is an important factor to consider in language revitalization programs where learning an endangered language can feel like an enormous responsibility. If students simply love it and enjoy it in and of itself, sustained motivation and commitment is more likely.

\section{Affective motivation as a moral responsibility.}

The second type of Affective Motivation related to a sense of responsibility to save a dying language, closely related to the Preservation theme. Fishman (2002, p. 83) discusses the sense of moral imperative people feel towards preserving their language as one of three facets of positive ethnolinguistic consciousness. Additionally, Dörnyei's (2009) conception of the Ought-to Self, as discussed in the literature review on motivation, points to attributes one believes one ought to possess to meet expectations and avoid possible outcomes. Perhaps the two participants were seeking to fully express themselves as they thought they ought to be, based on their Ought-to selves. 
Billy and Kakwa tsiltsil, both non-Natives, felt a strong personal, moral, and social responsibility to save this language. I include this in the affective motivation because both participants were passionate about this stance in their descriptions of this motivation.

Billy reports that his feeling of responsibility had ebbed over the duration of his participation with the Chinuk Wawa community, but part of his initial motivation to learn Chinuk Wawa included a sense of moral obligation that he felt to save the language. He shared that he had been raised in a very religious family by missionary parents. When I asked if he saw any links between his motivation to study Chinuk Wawa and that religious upbringing, he responded by saying, "Oh for sure, let's go out and save this language. I'm going to come in and do some good. I'm gonna save this thing....That's absolutely how I walked into it." He went on to say that his perspective has changed somewhat. "I see some hollowness and falsehood in that feeling. ... it's not really my thing to save. I see the inappropriateness of that." He further remarked, "This sense of crusade, I don't have that much anymore" (Billy). Even without moral responsibility as primary motivating factor, Billy has continued to be motivated and active within the Chinuk Wawa language community.

Kakwa tsiltsil expressed a similar sense of responsibility, though he did not relate it to a religious upbringing. He stated, "The fact that it could disappear is almost unconscionable. Maybe that's why I do it. But it's meant to be here." (Kakwa tsiltsil). Kakwa tsiltsil expressed that if Chinuk Wawa were to become extinct, it would be the final blow to Pacific Northwest Native American Chinuk Wawa-speaking cultures after 
many systematic attempts of cultural assimilation of PNW tribes over the past 200 years. Kakwa tsiltsil was referring to the cultural and linguistic genocide of Native American people. For both Billy and Kakwa tsiltsil, as non-Native, this type of motivation may stem from a sense of responsibility over the historical exploitation and trauma suffered by Native American people. They see learning Chinuk Wawa and contributing to its revitalization as a way for non-Natives to contribute to the healing of historical wrongs and work in collaboration with tribes to create a fairer and more equitable paradigm.

\section{Theme 6: Self-ascribed identity as a member of the Chinuk Wawa language} community.

Participants' self-ascribed identities were intertwined with their motivations for learning and teaching the Native version of Chinuk Wawa. In all cases, learning or teaching Chinuk Wawa served to reinforce participants' already existing identities. According to Norton, previously discussed in the literature review, "an investment in the target language is also an investment in a learner's own identity" (2000, p. 11). In this community of people learning the Native version Chinuk Wawa, the social positioning of all participants oriented around Native/non-Native identity, a salient social variable of this community. Native participants reported they were motivated to learn Chinuk Wawa because of their Native identity. By learning and speaking Chinuk Wawa, they saw themselves as strengthening their Native identity, contributing to their tribes, and doing what their ancestors did before them. Non-Native participants explained their desire to learn Chinuk Wawa in terms of other, non-Native identities: linguist, endangered language activist/teacher, plant- and earth-oriented, Oregonian, 
and Pacific Northwest dweller. Non-Native members of the Chinuk Wawa language community positioned themselves according to these identities, which provided them with a sense of belonging to the classes and community. This sense of belonging was a motivating factor for them and provided them with roles to fulfill within the community.

\section{Tribally-affiliated participants.}

Three of the eight participants identified themselves as official members of Pacific Northwest Native American tribes. Their identity as tribal members was central to their motivations to be involved in the Chinuk Wawa language community. T-1's motivation to learn Chinuk Wawa was inextricably linked to his identity as a tribal member. "I'm a member of the Confederated Tribes of Grand Ronde and being involved with the tribe, and Chinuk Wawa is one of our tribal languages that is used" (T-1). Later in the interview he stated, "It's [Chinuk Wawa] just a part of me. Just part of me, I guess being our tribe so, part of our community" (T-1). Additionally, T-1 conducts cultural classes at the Portland tribal office, and, thus, learning Chinuk Wawa was related to his job as well. The same participant was also motivated to learn Chinuk Wawa because of his other tribal family connections. Learning Chinuk Wawa was a bridge to the languages of those other tribes:

So that's kind of where my real interest is just that ... 'cause I'm also Clackamas so really interested in Kiksht or the Clackamas language, and the other Chinookan, both Chinookan languages. So that's kind of where ... my real interest is. (T-1) 
Another participant shared two relevant identities. She described herself as a language or word person as well as a member of a Pacific Northwest tribe. The tribal identity superseded her identity as a language person. Because she was a member of a tribe, that's the community to which she offered her language ability:

I've gone through lots of phases about what it means to be an Indian, Native American, and what it means to be a member of my tribe. ... And I was events coordinator for three years, but ultimately, everybody has their gifts, I'm a language person. I'm a word person. So whatever I'm going to bring to my tribe. (Charley Horse)

She had spearheaded a language class to teach Chinuk Wawa to members of her tribe. Her decision to become a Chinuk Wawa speaker and teacher was her own prerogative: "I think that my people need to learn this language. I think that it's important to their identity. My vision is that I help my people learn it. I think it's important to their identity and their future" (Charley Horse).

Another Native American participant, ShawashB, came to be involved with Chinuk Wawa revitalization though another route. He grew up outside of his Native community, and it was not until he was 13 years old that became a tribal member. At about the age of 18 , he started receiving checks from the CTGR, and he reported that he was concerned about receiving money that he did not earn: "So I had to find out what was going on and that's when I started becoming involved in my tribe. And eventually that led me here to the language" (ShawashB). His initial awareness of being a tribal member was through the money he received from the tribe. 
Learning and teaching Chinuk Wawa was a way for ShawashB to strengthen his Native identity: "So I've always been told I'm Native, and always been told to respect that. But it's only been probably the past 10 or 12 years that I've really gotten into being Native" (ShawashB). Chinuk Wawa, as the last Native language spoken at CTGR, was a strong marker of Native identity for ShawashB. He referenced Grand Ronde elders who had taught Chinuk Wawa to the Grand Ronde community in the 1980s. "And it's an identity thing. This is who we are. This is our identity. And my ancestors, some of CTGR's ancestors, especially Eula Petite and others thought it important to keep alive" (ShawashB). He stressed that Eula Petite had actively taught it as a spoken language. He distinguished that type of preservation from simply documenting and archiving the language.

Kanim was part Native from an Eastern American tribe. She did not, however, identify as culturally Native American, and her Native heritage was not her motivation for learning Chinuk Wawa. She discussed her ethnic identity by stating: "Anyway, but non-Native basically non-Native" (Kanim). She reported that because she was not raised in a traditionally Native manner, she did not consider herself to be culturally Native American. She did not claim her Native heritage as an important factor in her involvement with the Chinuk Wawa language community.

Non-tribally affiliated participants: linguist, endangered language activist/teacher, plant- and earth-oriented, Oregonian, and Pacific Northwest dweller.

Five of the eight participants defined themselves as not having a tribal affiliation; however, for all of them, at least one of their multiple identities played into 
their motivations for learning/teaching Chinuk Wawa. These identities also provided the non-Native participants with a sense of belonging to and legitimacy in the Chinuk Wawa community. Non-Native participants talked about identities that were relevant to their motivation to learn Chinuk Wawa: linguist, endangered language activist/teacher, plant- and earth-oriented, Oregonian, and Pacific Northwest dweller. Kakwa tsiltsil defined himself as "white" as well as a "plant" person. He stated: "I have more plant energy, so I see it more in plants" (Kakwa tsiltsil), he said when speaking about using Chinuk Wawa. Kakwa tsiltsil initially came to the CTGR Portland Tribal office because he was interested in camas root, the food plant indigenous to the PNW. He was looking for Native Americans who traditionally harvested camas root because he wanted to preserve and revitalize camas root populations in the Pacific Northwest:

And I couldn't find anybody. I'm like, 'I don't think there is anybody left.' I kept looking looking. And that, so I was using my Chinook to try to find some root diggers. See I'm more of a plant, plant medicine, so I, that's why I took you to see those plants, that's what I want to work on. (Kakwa tsiltsil)

Kakwa tsiltsil's identity as a plant person motivated him to come to the classes in the first place, but once in the classes, his identity as a plant person also gave him a specific role in the community. He talked about his efforts to learn about CTGR tribal members' connection to camas. He grew several different varieties of camas in his back yard which he shared with tribal members to plant in their own yards or areas where camas traditionally grew. He found that there were still root diggers in the CTGR tribe 
harvesting camas traditionally. He also stated that once he found out about the state of Chinuk Wawa, preserving Chinuk Wawa became an equal priority for him.

Kanim claimed heritage from an Eastern American tribe but did not identify as Native. Additionally, she was a professor with a local university. I describe Kanim as earth-oriented in that she spoke about her relationship to the land and the Northwest as being a defining aspect of who she was and her choice to study Chinuk Wawa.

Nettle described himself as a non-tribal, language teacher. He positioned himself as not being a linguist. "It's funny because I'm not a linguist, I don't have the linguistic training. I honestly wish I did 'cause it would have helped under certain circumstances" (Nettle).

Keyskeys, described himself as a "linguist," and an "Oregonian." In response to the question, "How do you feel about speaking this language as a white person?" this participant replied, "Well, as a linguist let's say. I just had this role as being a linguist and it seems to be fairly accepted down among the people at Grand Ronde" (Keyskeys). Keyskeys's linguistic identity was based his orientation to and experience with the CTGR Grand Ronde community.

Billy described himself as non-tribal as well as a "linguist" and an "academic packrat." When referring to all of the archived language materials, Billy stated: "Well, all this stuff was collected and gathered by these packrat academics you know. My people. I'm totally one of those people" (Billy). In one interview, Billy's wife was in the room during the interview. At one point when we were talking about whether or not his priorities or interests had changed since learning and teaching Chinuk Wawa, she 
interjected that Billy had been a closet linguist before his involvement in the Chinuk Wawa language community, and now he is much more active as a linguist. Keyskey's and Billy's identities as linguists were closely tied to their motivation for involvement with Chinuk Wawa.

The issue of identity also was apparent in that non-Native participants distanced themselves from claiming Native or tribal identity by repeatedly stating their lack of tribal identity. "But there's a level of cultural identity that I don't claim, and I don't want to claim. And it would be looked at with a raised eyebrow if I were trying to claim that" (Billy). Kakwa tsiltsil talked about knowing Chinuk Wawa as a "white" person and trying to teach it to CTGR tribal members: “There's really not that many people [CTGR tribal members] that know it ... you want to approach the subject gracefully, when you're trying to speak Grand Ronde tribal member's language. With me particularly being white" (Kakwa tsiltsil).

Billy stated his positioning in terms of his relationships with Native people in the Chinuk Wawa language community:

Not that I count myself in that Native language community but I've done it long enough now that those people are my friends, and if it's important to them it's important to me. So, even though I don't identify myself as necessarily part of that community, that involvement I think is, keeps me coming back, or keeps me involved. (Billy)

Though being Native was not a requirement to be a part of this community, it was a salient marker of identity and legitimacy within the community. Non-Native 
participants seemed to be very aware of being white in this community. Linguists had a legitimated position within this language community even though they were not tribal members. This process of legitimization was not a clearly delineated process. However, one Native participant, also the cultural coordinator at the Grand Ronde tribal office, spoke about contributions of linguists, linguistic students, and other volunteers in response to a question about opinions he may have heard about non-Native people studying Chinuk Wawa. He spoke about non-Native college students and community people, Chinuk Wawa students, who contributed to the program and as well as to other projects. Additionally, he mentioned that he had learned a lot from a non-Native Chinuk Wawa speaker and teacher. He gave credit to non-Native people's contributions to the Chinuk Wawa language preservation and had only positive comments about their involvement.

Another Native participant responded to the same question about opinions she may have heard about non-Native people studying Chinuk Wawa by laughing at the absurdity of such a suggestion. She then discussed the diversity of Chinuk Wawa's speakers at its height in the 1800s:

Well, my goodness, Chinuk Wawa was spoken up and down the Coast in the 1800s by everyone. I mean it was a workman's language. ... Everybody came here for timber and fish, salmon and logging, so that's how the Northwest was developed. And those were inherently involved with Native Americans. (Charley Horse) 
Thus, she did not report a feeling of exclusion to non-Native Chinuk Wawa community members.

ShawashB, the third Native participant responded to this same question by stating that he was most concerned about getting more people speaking Chinuk Wawa regardless of their affiliations. However, he did have some conditions for that warm welcome:

I want to include everybody I can get in the door who is not going to take Chinuk Wawa with them and go try to claim Native heritage that doesn't exist. Or go out there and be a plastic shaman -someone who says 'I can do all the Native practices.' (ShawashB)

He went on to state that he welcomed anyone with a good heart and thought that he and the other teachers did a good job of screening people who fit this criteria. The above quotes report perspectives of the three Native participants regarding people with non-Native cultural identities and backgrounds.

On an institutional level, the CTGR Portland tribal office has had varied policies regarding level of inclusivity. When I first began going to the tribal office for Chinuk Wawa classes in May, 2008, I was welcomed as a non-Native person interested in learning Chinuk Wawa. The only time an ethnic distinction was explicitly made was when I wrote my name on the attendance sheet. On it, there was a column asking students to specify their tribal-affiliations. In March 2009, the classes offered changed the conditions for participation at the tribal office in Portland; the classes were only open to CTGR-affiliated members. That changed in February 2012; and now again, 
everyone is welcome and all students write their names as well as their tribal-affiliation on the attendance sheet.

\section{Theme 7: Demotivation - reasons for not continuing to learn or teach Chinuk Wawa, or reasons that it was difficult to continue.}

This theme encompassed negative beliefs, experiences, feelings, and interactions that contributed to demotivation to learn and/or teach Chinuk Wawa. Demotivation has been studied fairly extensively in the field of second language acquisition (Hamada, 2011; Dörnyei, 2001). As stated in Hamada (p. 16) , Dörnyei (2001, p. 142) defined a demotivated learner as "someone who was once motivated but has lost his or her commitment/interest for some reason." This was precisely the case in the Chinuk Wawa language community where all participants were highly motivated when they first began to learn Chinuk Wawa, but through various demotivating factors, their level or nature of motivation shifted. Seven of the eight participants had at least one negative comment unique to his or her experience. This section serves to highlight factors that made involvement challenging or impossible for members. By including this section, I hope that language revitalization communities will consider what may be challenging for committed members and how to avoid or ameliorate reasons for demotivation. Though, in some cases, there is no easy solution.

\section{Attitude about time spent in front of computer.}

Keyskeys, a non-Native participant, commented that, past a certain point, the work of documenting Chinuk Wawa began to make him feel like a "data drudge." His involvement in Chinuk Wawa included working on many database projects, writing articles about Chinuk Wawa, and compiling a Chinuk Wawa dictionary, a project that 
spanned many years. He said it was ironic that while he was initially interested in Chinuk Wawa because of its connection to Northwest Native life ways, in this work he spent most of his time inside working on a computer: "As a result of my love of nature I became a data drudge" (Keyskeys). Keyskeys still enjoyed speaking Chinuk Wawa and was actively involved in teaching and documenting the language, but his involvement in Chinuk Wawa revitalization had left him feeling "burnt out" because of all the time spent in front of a computer.

\section{The time commitment.}

One participant talked about the time commitment of being involved with Chinuk Wawa: "It eats up time; it eats up valuable time that could be used doing other things. But generally it's a good thing; it's a positive not a negative" (Billy). This participant is still actively involved. Thus, while the issue with the time commitment made his involvement more difficult, it was not completely demotivating for him.

\section{Lack of financial support.}

Nettle was initially motivated to learn Chinuk Wawa as a way to further hone his method of teaching endangered languages. He described the demotivating aspects of working as a Chinuk Wawa teacher and organizer for no pay as discussed in the section about instrumental motivation. Initially and intermittently, he was paid for the bulk of his teaching work. But in one case, he volunteered his teaching skills to teach Chinuk Wawa community classes, and his sense of financial sacrifice led to his giving up the class as a teacher: 
We didn't get paid for any of that. And so I was having to work and find other jobs and pay gas. It cost me $\$ 20$ bucks every time class happened so I didn't make any money so I was just sort of like, 'Well you guys take over'. (Nettle) Nettle evaluated the costs of his investments compared to the benefits from pursuing his 'Where are your Keys' method of teaching endangered languages. He reported feeling frustrated with the outcome of his evaluation:

That probably has been the worst part is that because I haven't necessarily had a steady income. And that's been the most frustrating thing is that I've got this idea that I know works, and it's cost me too much. (Nettle)

Nettle stated that he was no longer motivated to be involved with Chinuk Wawa revitalization by stating: "Yes, I'm no longer motivated. Yep, I'm no longer motivated" (Nettle). He is the one participant of this study who is no longer involved in teaching or organizing Chinuk Wawa classes, though at least three of his students are now actively organizing and teaching classes using the method he developed. In this way, his contribution to Chinuk Wawa revitalization remains active.

\section{Appropriate use of Chinuk Wawa in non-Native, not historically traditional contexts.}

Who can use Chinuk Wawa and in what contexts? These were some of the concerns of two non-Native participants who discussed their beliefs and experiences regarding speaking Chinuk Wawa in other domains.

Kanim mentioned several times in the interview that she would like to use Chinuk Wawa in the context of a women's spirituality group in which she was involved, but she was also concerned about culturally appropriating the language: 
So can we use this language in other spiritual contexts? It's one of the questions that needs to be talked about and answered, because if it's going to be a language, languages are used everywhere... but you run that fine line again of cultural appropriation. (Kanim)

Kanim brought up the issue of where Chinuk Wawa could be used and voiced her frustration about the unclear boundaries regarding the appropriate use of Chinuk Wawa in non-traditionally Native contexts.

Kanim and Nettle, both non-Native participants were concerned about the possibility of using Chinuk Wawa in a way that could be construed as cultural appropriation. Kanim was comfortable attending Chinuk Wawa classes only after a close Native friend invited and encouraged her to come. Kanim acknowledged her lack of Pacific Northwest Native heritage and lack of connections to the Grand Ronde tribe as well as her desire to avoid any sense of cultural appropriation.

Nettle, a non-Native Chinuk Wawa language teacher, contrasted teaching Chinuk Wawa to teaching Spanish. He reported feeling worried about how others would view his teaching of Chinuk Wawa:

The difference between teaching that and say Spanish.... is that there's no political baggage that comes along with it. So I can I can teach anybody I want some Spanish. And I can do whatever I want with it. I can record it, I can post it on YouTube, ... I don't have any worry about somebody saying, 'Oh, that white guy came and took our language.' (Nettle) 
Both participants reported feeling conflicted about how they wanted to use the language in aspects of their lives while avoiding cultural appropriation of Chinuk Wawa. The burden of responsibility to act appropriately without knowing what that exactly looked like seemed difficult for these two participants.

Another non-Native participant, Billy discussed how teaching a Native language and Native culture as a non-Native felt "schizophrenic" to him:

I obviously don't claim that cultural identity so it's sort of this schizophrenic life. Teaching about a culture that isn't mine that is, you know, there aren't that many people who can teach about it. . I want somebody else to do it, but if no one else is going to do it then I guess I will. (Billy)

When I asked why he continued to teach given this schizophrenic nature of his involvement, he replied: “Well, [I'm] getting out of it" (Billy). Billy is still involved in the Portland Chinuk Wawa language community. He comes to classes and has organized a Chinuk Wawa writing group. He decided to stop teaching a high school class after one year partly because he felt the class would be better taught by a Native person. Additionally, he had conflicting professional plans that did not allow him to commit to teaching another year.

\section{Attitudes about Chinuk Wawa as a pidgin language/partially Native American language.}

Charley Horse and Nettle discussed their reactions to learning Chinuk Wawa as a pidgin language with a limited lexicon. Charley Horse, a Native participant, who was learning another, non-pidgin Native language before and while learning Chinuk Wawa stated: "I was resistant to learning Chinuk Wawa because I felt like it was just a watered 
down, amalgamated version of" another Native language (Charley Horse). Additionally, she reported feeling frustrated by the dearth of vocabulary in Chinuk Wawa. But this resistance and frustration did not keep her from learning and teaching Chinuk Wawa. In fact, she was a strong proponent of Chinuk Wawa as a teacher and organizer of classes.

Nettle, a non-Native participant, had been exposed to many languages as a child because his parents ran an exchange program. He talked about his somewhat romanticized expectations and subsequent disappointment about learning Chinuk Wawa: "I had this idea that that Indian languages would be like that's a 'makes for a really good fish skewer.' Like the plant would tell you what it's for" (Nettle). In reality, many Chinuk Wawa words are derived from French and English including words for plants. For example, a cherry tree is 'cholis' (derived from English) and the word for tree is 'stik' (derived from English) in Chinuk Wawa (Confederated Tribes of Grand Ronde, 2011).

Keyskeys talked about the difficulty in making the effort to speak Chinuk Wawa all the time since English is the dominant language of all those who also speak Chinuk Wawa: “It depends on how inspired I feel to talk Chinuk Wawa, or if I'm starting to feel a little lazy "cause it's always easier to talk in English" (Keyskeys). This is a common situation in learning endangered or heritage languages because students and teachers almost always share a different common language which is simply an easier and more efficient means of communication. 


\section{Overlapping Themes}

In an effort to analyze motivations in this multi-faceted community, I found that the themes overlapped in interesting ways. For example, the Preservation and Relationships themes overlapped as evidenced in the following quotes from Billy, a non-Native participant: "hilu tilixam, hilu wawa [translation: without people, there is no talking/language]" (Billy). In this comment, Billy pointed out the importance relationships to the preservation of Chinuk Wawa.

When Kanim talked about the importance of Chinuk Wawa, she interwove three themes, Relationships, Connections, and Preservation:

To me, things like keeping a language alive in a community is important too. Because it creates, it preserves the interconnection between generations and between history and today and the future and the people and the place. I already talked a lot about that, but it preserves those connections. And allows people who aren't yet connected to connect, which is why I think it's so important for the future. (Kanim)

She discussed the connections between generations of people as well as history and place. Then, she discussed potential relationships between people. And she discussed the importance of preserving those connections and relationships. For Kanim, Chinuk Wawa was a nexus where many different aspects of life intersected.

Demotivation and preservation overlapped. Some factors that contributed to participants' demotivation at times also contributed to their motivation to preserve the 
language. Kakwa tsiltsil discussed this overlapping of motivations in the following quote:

But I do, I also go back because I, there's nowhere else to speak it. I have this language where there's very few people that I can talk to. So that's kind of why I keep going back. It's sort of like, if you don't use it, you lose it. I enjoy speaking it and hearing it, but that's the only place I get to, in fact now, that's the only place to go to speak Chinook Jargon. What a lonely, I mean you can't talk to yourself, really, that's not a living language. (Kakwa tsiltsil)

At times, Kakwa tsiltsil was saddened by the lack of other speakers, at other times, this lack of speakers motivated him to continue coming to Chinuk Wawa classes.

One participant, T-1, spoke about different aspects of his life in a way that showed how intertwined the themes were in his life. T-1 was a tribal member who worked for CTGR as a cultural educator, and five of the seven themes were prominent themes in his interview. I summarize his interview and reference the applicable themes in parenthesis to show how they overlapping in his case.

T-1's identity was as a tribal member (IDENTITY). He was connected to Native culture and this place as his home as well as the home of his ancestors (CONNECTION), and he worked to preserve Chinuk Wawa both in his personal and professional lives (PRESERVATION/INSTRUMENTAL). In addition, his relationships with his family members motivated him to learn Chinuk Wawa (RELATIONSHIPS). He did not express much emotion during our interview nor did he have anything negative to say about his experiences or opinions of others in learning or teaching Chinuk Wawa. 


\section{Timeline of Participants' Motivations}

Based on Dörnyei's process model of learning motivation for the L2 classroom (Ellis, 2008), Table 4 indicates each participant's motivation as it evolved over the course of their involvement with Chinuk Wawa. According to Ellis, "such a model is able to account for how motivation changes over time. . . It is also capable of integrating other models of motivation" (p. 68). This is not the primary construct that I chose to use to analyze my data, but it is a useful addition to the discussion because it displays the chronological evolution of each participant's motivation. The 'preactional stage' refers to the initial choice to learn the language. The 'actional stage' refers to the "effort the learner is prepared to invest to achieve the overall goal and which is heavily influenced by the quality of the learning experience" (Ellis, 2008, p. 688). The 'postactional stage' refers to an evaluation process by the learner where they decide how to proceed next. 
Table 5

Timeline of Participants' Motivations

\begin{tabular}{|c|c|c|c|}
\hline $\begin{array}{l}\text { Participants' } \\
\text { Pseudonyms }\end{array}$ & $\begin{array}{l}\text { 'Preactional Stage' } \\
\text { Why participant } \\
\text { decided to learn } \\
\text { Chinuk Wawa }\end{array}$ & $\begin{array}{l}\text { 'Actional Stage' } \\
\text { Process of learning } \\
\text { Chinuk Wawa to } \\
\text { an intermediate } \\
\text { level }\end{array}$ & $\begin{array}{l}\text { 'Postactional } \\
\text { Stage' } \\
\text { Continuing } \\
\text { Commitment to } \\
\text { Chinuk Wawa }\end{array}$ \\
\hline Billy & $\begin{array}{l}\text { To fulfill academic } \\
\text { requirements, } \\
\text { because Chinuk } \\
\text { Wawa was a local } \\
\text { language, language } \\
\text { community was open } \\
\text { to newcomers }\end{array}$ & $\begin{array}{l}\text { Came to classes } \\
\text { even though family } \\
\text { commitments were } \\
\text { high, came to all } \\
\text { available Portland } \\
\text { classes, at PSU } \\
\text { (offered through } \\
\text { LCC and CTGR } \\
\text { Portland Tribal } \\
\text { office) }\end{array}$ & $\begin{array}{l}\text { Taught Salem class } \\
\text { through Lane } \\
\text { Community College, } \\
\text { taught at NAYA for } \\
\text { one year, organized } \\
\text { and facilitated } \\
\text { writing group } \\
\text { during two separate } \\
\text { time periods, } \\
\text { attended } \\
\text { Wednesday night } \\
\text { classes at tribal } \\
\text { office }\end{array}$ \\
\hline $\begin{array}{l}\text { Charley } \\
\text { Horse }\end{array}$ & $\begin{array}{l}\text { Because other tribal } \\
\text { members thought } \\
\text { Chinuk Wawa was } \\
\text { more available and } \\
\text { possible to learn than } \\
\text { older, local } \\
\text { indigenous languages }\end{array}$ & $\begin{array}{l}\text { Attended classes at } \\
\text { NILI, classes } \\
\text { through LCC in } \\
\text { Salem and Portland, } \\
\text { attended writing } \\
\text { group }\end{array}$ & $\begin{array}{l}\text { Helped organize } \\
\text { writing classes, } \\
\text { organized } 3 \text { classes } \\
\text { for Columbia River } \\
\text { tribe, and worked to } \\
\text { create a Chinuk } \\
\text { Wawa class at the } \\
\text { Ridgefield } \\
\text { Plankhouse }\end{array}$ \\
\hline ShawashB & $\begin{array}{l}\text { Tribal member of } \\
\text { CTGR, came because } \\
\text { of other family } \\
\text { members' } \\
\text { involvement in tribal } \\
\text { classes/activities }\end{array}$ & $\begin{array}{l}\text { Learned through } \\
\text { classes at CTGR } \\
\text { Portland Tribal } \\
\text { office }\end{array}$ & $\begin{array}{l}\text { Taught class at } \\
\text { tribal office, taught } \\
\text { at PCC, volunteer } \\
\text { taught at Ft. } \\
\text { Vancouver, } \\
\text { maintained blog } \\
\text { about Chinuk Wawa }\end{array}$ \\
\hline Keyskeys & $\begin{array}{l}\text { Never consciously } \\
\text { intended to learn } \\
\text { Chinuk Wawa, did a } \\
\text { graduate research } \\
\text { project about Chinuk }\end{array}$ & $\begin{array}{l}\text { Learned Chinuk } \\
\text { Wawa as byproduct } \\
\text { of graduate } \\
\text { research project of } \\
\text { the Grand Ronde }\end{array}$ & $\begin{array}{l}\text { Helped create } \\
\text { orthography for } \\
\text { Chinuk Wawa, } \\
\text { directed } \\
\text { compilation of the }\end{array}$ \\
\hline
\end{tabular}




\begin{tabular}{|c|c|c|c|}
\hline & $\begin{array}{l}\text { Wawa use in Grand } \\
\text { Ronde }\end{array}$ & $\begin{array}{l}\text { community through } \\
\text { speaking with } \\
\text { elders and studying } \\
\text { his recordings and } \\
\text { transcripts }\end{array}$ & $\begin{array}{l}\text { Chinuk Wawa } \\
\text { dictionary, helped } \\
\text { organize immersion } \\
\text { pre-school and } \\
\text { kindergarten in } \\
\text { Grand Ronde, } \\
\text { taught LCC classes, } \\
\text { worked on database } \\
\text { and archiving } \\
\text { projects }\end{array}$ \\
\hline Kanim & $\begin{array}{l}\text { Initially wanted to } \\
\text { learn Chinuk Wawa } \\
\text { since } 4^{\text {th }} \text { grade, a } \\
\text { Native friend invited } \\
\text { her to the } \\
\text { community classes at } \\
\text { CTGR Portland Tribal } \\
\text { office }\end{array}$ & $\begin{array}{l}\text { Attended PSU and } \\
\text { classes at tribal } \\
\text { office, attended } \\
\text { PCC class (Winter, } \\
\text { 2011), attended } \\
\text { community class at } \\
\text { NAYA (Spring 2010) }\end{array}$ & $\begin{array}{l}\text { Attended classes } \\
\text { when she could, } \\
\text { hosted a Chinuk } \\
\text { Wawa conversation } \\
\text { group with } \\
\text { housemates once a } \\
\text { week }\end{array}$ \\
\hline Kakwa tsiltsil & $\begin{array}{l}\text { To find tribal } \\
\text { members interested } \\
\text { in harvesting camas } \\
\text { root; and then soon } \\
\text { after, committed to } \\
\text { saving Chinuk Wawa } \\
\text { for the CTGR people }\end{array}$ & $\begin{array}{l}\text { Attended tribal } \\
\text { office community } \\
\text { classes, LCC classes } \\
\text { PCC class }\end{array}$ & $\begin{array}{l}\text { Came to tribal office } \\
\text { classes as active } \\
\text { participant, taught } \\
\text { small groups if } \\
\text { needed, supported } \\
\text { community class } \\
\text { teacher }\end{array}$ \\
\hline $\mathrm{T}-1$ & $\begin{array}{l}\text { Worked for the CTGR } \\
\text { coordinating classes }\end{array}$ & $\begin{array}{l}\text { Organized tribal } \\
\text { office classes, } \\
\text { worked with CTGR } \\
\text { consulting linguist, } \\
\text { attended some LCC } \\
\text { classes at tribal } \\
\text { office }\end{array}$ & $\begin{array}{l}\text { Organized classes, } \\
\text { gave talks about } \\
\text { Chinuk Wawa, } \\
\text { drove another } \\
\text { teacher to classes in } \\
\text { Portland and } \\
\text { Eugene }\end{array}$ \\
\hline Nettle & $\begin{array}{l}\text { Needed a language to } \\
\text { test and develop a } \\
\text { language } \\
\text { learning/teaching/ } \\
\text { revitalization } \\
\text { tool/method }\end{array}$ & $\begin{array}{l}\text { Learned Chinuk } \\
\text { Wawa through } \\
\text { immersion by } \\
\text { attaching himself to } \\
\text { linguist who had } \\
\text { learned Chinuk } \\
\text { Wawa from Grand } \\
\text { Ronde elders }\end{array}$ & $\begin{array}{l}\text { Taught tribal office } \\
\text { community classes } \\
\text { (2006-2011), taught } \\
\text { unaffiliated } \\
\text { community class, } \\
\text { worked one-on-one } \\
\text { with PSU student }\end{array}$ \\
\hline
\end{tabular}




\section{Participant-Observation Results}

In this section, I introduce my note-taking protocol, discuss the case context, and explore connections between my observations and participants' motivations. Participants' attendance, roles within the classes, conversation topics, and the objects they brought all served as corroborating evidence for motivations for their involvement in the Chinuk Wawa language community. Over a period of seven months, I took notes on 18 Portland Chinuk Wawa classes at the CTGR Portland tribal office. I attended each of these classes for 1-3 hours. My interviews were separate from these classes. While observing, I took notes on the following items:

1) Who attended the Chinuk Wawa classes

2) What the participants were doing (i.e. roles during classes)

3) Conversation topics

4) Objects participants brought

The first item, who attended classes, was important to record because presence in the class reflected investment in some aspect of Chinuk Wawa, and was therefore important information in terms of motivation. The second item, what participants were doing (or participants' role in the class) corroborated information that I gathered during the interviews about participants' motivations. Roles that I observed during the classes included teaching or assisting classes, or working on other Chinuk Wawa linguistic documentation projects. I recorded the third item, conversation topics, to add richness to the description of the Chinuk Wawa language community. I compared the conversation topics from class observations to the interviews transcripts to check if 
the participants' information about their motivation and involvement was consistent. The final item, objects participants brought, provided further information showing each participant's unique orientation to Chinuk Wawa.

Since I was both a participant and an observer, my notes are jottings of what was going on, and are not complete or comprehensive notes about the entire class session. In addition, on one occasion when I came early and there were no students or teachers, I catalogued all of the physical objects that I observed in the rooms where the classes were held. A description of the location and classrooms follows. The location and classrooms

The classes took place in the CTGR Tribal office in Portland, located in a large office building adjacent to a busy thoroughfare. To get to the classrooms, one must walk down a corridor with signs to other businesses as well as the CTGR offices. The Chinuk Wawa classes were held in two rooms. One set up like a class room with four long tables facing a large screen and the other was a kitchen with a large round table in the center of it. The first room was where the LCC distance-learning class was held. On the walls, there were drawings made by children, probably from the summer camp held this past summer. There were three whiteboards on which there were often lists of Chinuk Wawa words.

The kitchen served as the classroom for the community class. The teacher always provided some finger food for students because the class was held around dinner time and the teacher felt that having food was essential for sustaining the energy needed to learn Chinuk Wawa. Having food there also encouraged students to 
stay in class longer instead of leaving for dinner elsewhere due to hunger. There was a small whiteboard propped up on an almost empty display case, and written on the whiteboard were basic Chinuk Wawa verbs, pronouns, and words.

\section{Class attendance.}

When I began observing the classes in April, I was one of two or three people attending the LCC distance-learning class at the Portland site. In the spring, three students were in the LCC distance learning Eugene class, and in the fall, there were five students in that class. At this time there were no students in the community class. The teachers of the LCC distance-learning class and the community class were the most consistent attendees. More people, including participants of this study, started attending more regularly at the end of April and through the summer and fall.

\section{What the participants were doing.}

Two participants, Keyskeys and ShawashB were mostly teaching during the times I observed them. When not teaching, Keyskeys often worked on a laptop either alone or with other linguists on documentation projects.

T-1 usually worked on his computer in a little office off the classroom. He worked for the CTGR Portland tribal office and may have been doing his job at those points. He sometimes joined the classes to practice his Chinuk Wawa, but often he would not.

Kakwa tsiltsil and Kanim were actively involved in the classes as students or assistants. They mostly attended the community class. Billy and Charley Horse would participate in both the community and the LCC distance learning class as students. 
Kakwa tsiltsil and Billy would sometimes act as a teacher's assistant in the community class by suggesting teaching topics or guiding an activity.

Nettle did not come to classes during this period of observation. In the previous three years, during classes, he taught and actively engaged students of all levels. He facilitated pairing more proficient students with new students for one-on-one lessons.

\section{Conversation topics.}

History was a common conversation topic in both classes. Often the teacher, either Keyskeys or ShawashB in their respective classes, would discuss Pacific Northwest history in the context of the Chinuk Wawa instruction. Charley Horse would participate animatedly in these discussions, adding her own knowledge of Pacific Northwest history.

Pacific Northwest Native languages, like Kalapuyan, Tualitan, Tolowa, and others were a common topic of discussion, especially when Keyskeys, a linguist, was involved in the conversation. Different dialects of Chinuk Wawa from places along the West Coast of North America were also discussed. Between Billy and Keyskeys, Chinuk Wawa documentation, archival, and the dictionary project was a common topic of discussion.

Participants would very commonly discuss some aspect of the classes: lack of students, how to get more students to come to classes, starting new classes in different institutions, or creating lesson plans for other classes.

The participants, especially the more advanced Chinuk Wawa speakers, would often discuss personal topics in Chinuk Wawa, such as family issues, personal hobbies, 
gardening, canning, glitches with computers, broken-down cars, etc. At one class, we all sang happy birthday for T-1 in Chinuk Wawa.

\section{Objects participants brought.}

Kakwa tsiltsil often brought Native berries, plant materials he was using to make a basket, or other Native food plants like camas root. He talked about plants more than any of the other participants. His contributions of food and materials of local, native plants corroborated the information he provided in the interview. He also brought projects that he was working on for other traditional Native classes, like a shawl or a beaded necklace.

Billy often brought his digital audio recorder in order to record Chinuk Wawa as spoken freely by students and teachers. Additionally, he sometimes brought his son, a baby at that time, to the classes. Keyskeys and Billy often brought their laptop computers in order to work on documentation and archival projects. They also brought paper files related to those projects.

ShawashB brought hands-on teaching materials like decks of cards with Chinuk Wawa vocabulary and pictures posted on them. He also brought samples of berries, or Oregon grape root powder which is used medicinally. For teaching, he brought a flipchart for vocabulary which he used as a reference during lessons. Sometimes, he brought vocabulary lists for students that corresponded with the lesson for the day.

Charley Horse brought materials for studying a different Native American language, related to Chinuk Wawa. T-1 often worked on traditional Native craft projects 
like carving mini-canoes, drawing traditional Native designs, basket-weaving, or beading.

\section{Summary of the Discussion of Data}

The primary sources of data for this study included eight interviews as well as the information that I gleaned as a participant-observer. From the participantobservations, I presented a picture of the Portland Chinuk Wawa language community that included participants' attendance, activities in the class, conversation topics, and object brought. The data from the observations coupled with the themes from the interviews (Connection, Preservation, Relationships, Instrumental Motivation, Affective Motivation, Identity, and Demotivation) provided a nuanced and complex picture of this language community. A summary discussion follows.

With respect to the Connection theme, participants discussed their multiple motivations reporting how learning Chinuk Wawa connected Native participants with their Native ancestors and Pacific Northwest traditions and connected non-Native participants to the region. Overall, through learning Chinuk Wawa, participants reported strengthening a desired sense of belonging to a tribe, to the region, or to the earth.

Participants reported that part of their motivations to learn and teach Chinuk Wawa was to preserve the language. Within the Preservation theme there emerged several distinct motivations to preserve Chinuk Wawa including saving Chinuk Wawa from extinction and preserving it for future generations; expanding the range of Chinuk Wawa to previous norms; and preserving Chinuk Wawa for the CTGR 
community so that CTGR tribal members all speak it again. Preserving Chinuk Wawa motivated some participants because Chinuk Wawa is a gateway to other Oregon Native languages, and learning Chinuk Wawa is another way to honor and respect Native elders. A final motivation was that through revitalizing Chinuk Wawa other valued connections are preserved that are historical, generational, and ecological in nature.

In the Relationship theme, I documented participants as motivated by strong relationships with other Chinuk Wawa language community members. These strong relationships influenced participants to come to Chinuk Wawa class and then continue to be involved in the classes.

Participants cited different levels of instrumental motivation as factors for staying committed to learning and teaching Chinuk Wawa. Their level of motivation ranged from none at all to a long-term commitment to creating a dictionary funded by the CTGR.

Some participants expressed their motivation in terms of their emotions, coined affective motivation in this study. This theme included a general like or love of Chinuk Wawa as well as a sense of moral responsibility to save the language from extinction.

A record of demotivating factors was also included in hopes that these factors could be addressed in this and other language revitalization communities in order to strengthen community language revitalization efforts.

For the Identity theme, each participant shared, explicitly or implicitly, an aspect of their identity that was enhanced or strengthened through learning Chinuk Wawa. For the most part, learning Chinuk Wawa was a way to strengthen an already 
existing identity. Identities that were important within the context of the Chinuk Wawa language community included: Native American, linguist, earth/plant-oriented person, or endangered language activist/teacher.

As can be seen in Chapter Four as a whole and in this summary, participants' motivations were multifaceted, layered, and changing with new situations, challenges and opportunities. As stated in the literature review, Dörnyei describes this complicated notion of motivation: "Motivation concerns the fundamental question of why people think and behave as they do, and we should never assume that we know the full answer" $(2005, \mathrm{p} .66)$. While this study has presented a nuanced picture of participants' motivations by analyzing and teasing apart participants' reported motivations, it is only a partial picture of a changing and dynamic whole. 


\title{
CHAPTER 5
}

\author{
ANALYSIS AND CONCLUSION \\ In this chapter, I begin by restating the impetus motivating this research. Next, I \\ respond to the guiding questions posed, describe the implications of this study, and \\ finally, conclude the study.

\section{Restatement of Initial Motivation} \\ I chose this research topic because I of my intrinsic interest in the Portland \\ Chinuk Wawa language community, a community in which I had been participating for \\ two years before beginning work on this thesis. In the literature, I found no studies \\ about motivation in a community of Native and non-Native members speaking a \\ contact trade language. I was interested in asking my Chinuk Wawa classmates, \\ teachers, and colleagues about their motivations both out of curiosity, as well as out of \\ a desire to reflect on and explore my own motivations for learning Chinuk Wawa. \\ Additionally, the Chinuk Wawa language community is small and lacks \\ resources and committed people to strengthen and expand the language preservation \\ efforts. I saw that the conclusions of a study on participants' motivations would be \\ useful to language planners in preserving Chinuk Wawa and might apply to other \\ endangered language communities as well. Finally, I believed that doing a study on \\ Chinuk Wawa would expand general awareness that this language exists as do the \\ cultures and historical perspectives to which it is connected.
}




\section{Restatement and Answers to the Guiding Questions}

\section{Guiding questions 1 and 2.}

1. What reasons do participants report for choosing to learn and/or teach Chinuk Wawa?

2. Do participants report a link between choosing to learn and/or teach Chinuk Wawa and aspects of their identity? If so, what do participants report concerning the nature of this relationship/these relationships?

Seven themes emerged from the data as participants' reasons for choosing to learn and/or teach Chinuk Wawa as discussed in Chapter Four: Connection, Preservation, Relationships, Instrumentality, Affective motivation, Identity, and Demotivation. Among the seven themes that I identified as appearing most frequently in my participant interviews, the themes of Connection and Identity emerged as the most central, the heart of why participants chose to study Chinuk Wawa, and therefore worthy of further analysis. I found that the dimension of Identity was intertwined throughout the other themes in interesting ways. In the discussion that follows, the dimensions of Connection and Identity are interwoven. Each participant reported a different reason for choosing to learn and/or teach Chinuk Wawa.

\section{Theme 1 - Learning Chinuk Wawa as a way to connect to Native culture, the Pacific Northwest, and to participants' spirituality.}

This theme lay at an intersection between language and culture. For participants, Chinuk Wawa was a portal or an entry point into another worldview and culture. Through learning and teaching Chinuk Wawa, participants were able to gain access to PNW Native cultures. 
In the literature, I found links between speaking Native languages and connecting to Native traditions. Bunte (2009, p. 175), in researching language socialization and Paiute identity, found that the San Juan Paiute tribe had specific beliefs about the power of the Paiute language. One of these beliefs is that children learn the proper way of behaving if they are advised how to behave in the Paiute language. And even if they do not act on the advice or wisdom immediately, the words will come to the child or adult "on the wind" as it were, when those words are needed.

Bunte also discussed the idea that a Native American language and Native American identity were not always explicitly linked. She discussed how an essentialized or iconized link between language and identity had developed among the Paiute between the years 1980 and 2000. During the process of creating a distinct identity from that of Navajos, on whose reservation the Paiute families were now living, the Paiute language became a salient identity marker for the San Juan Paiute tribe.

Similar to the Bunte's interpretation of the San Juan Paiute tribe's perspective on their language, Greymorning (1999) and Watahomigie (1998) both stated that their tribal languages were central to their Native identity and to the continued strength of their tribal communities. These beliefs reflect an active response to endangered languages which is a recent phenomenon in the world, at least on this scale of extinction. These beliefs also represent a move away from assimilation to dominant culture. The associated beliefs about how the language ties to tribal identity and culture could serve to personalize and strengthen the revitalization efforts. Since the language is at risk, beliefs that language is necessary for the survival of culture makes it 
a highly productive belief for language preservation because the belief calls people to protect the language itself.

Both Native and non-Native participants talked about being motivated to study Chinuk Wawa because they felt that the language encoded another way of being and another worldview. This alternative way of being or worldview motivated participants to continue their involvement because they wanted to be in touch with that different worldview. Haynes, an Oregon State University student working with endangered languages (2007) posited that without the Native language, tribes can still carry on their cultural traditions, but she added: "Nevertheless, language represents an implicit analysis of experience. People who speak Native American languages remark that it encourages them to think in different ways" (p. 76). The idea that a language somehow encodes another worldview or another way of categorizing is broached in the SapirWhorf Hypothesis, which posits that within different languages there are different "fashions of speaking" (Haynes, 2007, p. 77). Some participants thought that Chinuk Wawa conveyed the thoughts and worldviews of its previous speakers and thus communicated how Chinuk Wawa shaped those speakers' thinking.

Participants reported that they were motivated to learn Chinuk Wawa because it allowed them to connect to and explore realms not generally available in the modern world and somehow the Chinuk Wawa language itself carried the power to connect participants to that realm. Chapter Four presented the idea that describing an event using the language in which it occurred connected the telling more powerfully to the event. Joshua Fishman, a scholar and researcher of endangered languages worldwide, 
stated "A language long associated with the culture is best able to express most easily, most exactly, most richly, with more appropriate over-tones, the concerns, artifacts, values, and interests of that culture" (p. 81). As a case in point, T-1 pointed out that the Chinuk Wawa word ikanum [translation: legend or myth] could not be fully translated into English to express its full meaning as a word describing the creation stories of the Native people. Fishman (2002) corroborates the inability to fully translate concepts through a single word when they are conceived of very differently in other cultures: When people tell you that there is a cultural view of how that language came about, that it came about when the earth was created, when the worlds were created, when heaven and earth was created, when humanity was created, they are giving you what you might think of as a myth, but the importance of it is beyond its truth value. That is actually the definition of a myth-something that is so important that you hold on to it because it has an importance beyond its truth. (p. 82)

Fishman conveyed the idea that languages carry conceptions of worldviews not fully translatable to other languages, and something is lost when a language dies.

Non-Native participants described their connection in terms of feeling connected the earth and to a regional community (people, ecology, landscape, etc.). I did not find this theme stated as such in the literature, though it is referenced through Native cultural values regarding the earth. For example, Meek (2009) quotes Gardner and Associates about the values of Canadian Aboriginal people as "viewing life and everything in it as a gift from the Creator, being responsible for the care of those gifts, 
and striv[ing] for harmony with nature and fellow human beings" (p. 161). While Meek was not referring to Pacific Northwest Native people, based on my four years of involvement with the Chinuk Wawa language community that value of caring for the earth and striving to be in harmony with nature and the earth is a value that this community seeks to attain through reviving Pacific Northwest Native cultural traditions and knowledge. By speaking a language where similar values were understood to be a part of the daily life of the original speakers of the language, the participants reported feeling that connection through the language to the earth. As a participant-observer, I saw participants acting in ways that embodied valuing earth and living in harmony with it. For example, many participants drove older cars or bikes for transportation. Several participants were actively involved in other organizations or efforts to revive traditional uses of Native plants, teach people local history, or more deeply connect people to the earth.

This theme displays a contrast in worldviews between Native/Indigenous cultures and colonial cultures. In Native cultures, connection to the earth is understood as an inherent part of survival. Humans are an integral part of the earth and nature. In colonial cultures, humans are seen as separate from nature and in control of it. This difference in worldview is revealed in this sub-category. Part of the uniqueness of this community is that there are people raised in the dominant culture who are actively seeking to live in a way that includes this alternative worldview. These participants see Chinuk Wawa as a way to access and learn more about that alternative worldview. 
The category, Connection to participant's spirituality, was referenced in several articles by Native American authors concerning language revitalization. Often the reference did not make a direct link between Native American spirituality and a Native language, but the connection was there indirectly. One Navajo speaker, Velma Hale spoke on what speaking her language means to her: "It's important to maintain your language. My language is me, my ancestors, the roots of my existence.... We are who we are through our maternal ancestors, our home, church, attitude, behavior, ancestral people, Talking God, etc." (Reyhner \& House, 2002, p. 134). A similar sentiment was expressed by an Apache speaker “In English, it's just words, and you toss them together. But in Apache life is in everything, in the atmosphere and in the Mother Earth. It's a dynamic system. And that concept, that meaning, is in the language itself" (Gomez de Garcia, Axelrod et. al, 2009, p. 112). These two quotes evidence connections made between language and spirituality.

Theme 6: Self-ascribed identity as a member of the Chinuk Wawa language community.

This theme lay at the intersection of language and identity. Identity was an important source of motivation to participants for learning or teaching Chinuk Wawa. Ethnic or tribal identity was a source of motivation for Native American participants, as well as an important social variable in this community. After someone began attending classes, his or her identity was usually determined by a teacher asking the person about his or her tribal affiliations or lack thereof. New class members were generally forthcoming about their motivations to learn Chinuk Wawa. The desire to know class members' ethnic identity was tempered by the desire for active, committed students, 
teachers and organizers. New members were welcomed with open arms into the community partly because the community needs bodies to fill seats and speak Chinuk Wawa and partly because of the value of respecting people as they are regardless of affiliations. Non-Native participants each cited additional identities that somehow motivated their participation in the Chinuk Wawa language community. The three identities: Pacific Northwest Native American, linguist, and earth/plant-orientation show that Chinuk Wawa somehow symbolized external embodiment and expression of these identities for participants.

Dörnyei and Ushioda's (2009) L2 Motivational Self System was described in the literature review. Dörnyei's conceptualization of the Ideal L2 self is useful in understanding how participants were motivated to learn and teach Chinuk Wawa because of their Ideal L2 self. In this community, learning the language was part of a greater movement to revitalize the language itself. Based on participants' reported identities relevant to this community, it seemed that each participant's stated identity was in place before he or she decided to learn Chinuk Wawa. Through learning Chinuk Wawa, participants embodied parts of their Ideal L2 selves and strengthened already existing identities.

Vitality of the L2 community in Dörnyei's study referred to the perceived importance and wealth of the L2 communities in question. In reference to Chinuk Wawa, the perceived lack of vitality was motivating and explicitly stated as such by two participants, Billy and Kakwa tsiltsil. 
One Native American participant stated that Chinuk Wawa was just a part of him since it was one of his tribal languages. Since he was a part of the cultural target community, I suggest that his motivation to learn and teach Chinuk Wawa may have partially come from wanting to integrate more fully into his idealized version of the L2 community. Based on his stated motivations, as described in Chapter Four, he was interested in seeing Chinuk Wawa spoken again in the Pacific Northwest by other tribes who historically spoke it. Additionally, he may have been working towards becoming his Ideal L2 self as a member of this community. During the interview, he spoke about being able to do translations as requested by other members of his tribe. He said that because of his level of fluency in Chinuk Wawa, he felt comfortable making translations. Through learning Chinuk Wawa, I posit that he may have been working to embody his vision of himself as a fluent Chinuk Wawa speaker and able to support his community with these language skills.

Charley Horse reported that going through many stages and trying out different ways to relate to her Native heritage. Her motivation to learn Chinuk Wawa was related to her goal to strengthen her tribes' sense of Native identity. In terms of Dörnyei's model, the vitality of the L2 community (the perceived importance and wealth of the L2 communities in question) was her primary concern. Charley Horse was greatly invested in the vitality of her community and actively worked to create her vision of her community through learning and teaching Chinuk Wawa.

Instrumentality, the pragmatic utility of learning the L2, was a secondary motivation for half of the participants in my study. Though it was not the primary 
motivation for beginning to learn Chinuk Wawa and join the community, half of the participants did receive financial payment for services rendered in support of Chinuk Wawa preservation. I posit that their long-term involvement was at least partially supported by money they received.

Non-Native participants reported identities that supported their involvement in the Chinuk Wawa language community. Keyskeys and Billy both identified as linguists. This professional identity seemed to be a welcome one in the Chinuk Wawa language community as stated by all three Native participants in Chapter Four. In Dörnyei's L2 Motivational Self System, instrumental motivation is a precursor to integrativeness. He described instrumentality as motivational when people worked to achieve their idealized images of themselves as professionally successful. I posit that both Keyskeys and Billy experienced their involvement in the Chinuk Wawa language community as enhancing their Ideal L2 selves in a professional sense. Here, instrumental and integrative motivation are conceived as related aspects of achieving one's Ideal L2 self.

Cultural interest was defined by Dörnyei as “the appreciation of cultural products associated with the particular L2 and conveyed by the media; e.g. films, TV programs, magazines, and pop music" (p. 26). This dimension applied to both Native and non-Native participants. All participants wanted to learn more about PNW Native culture, whether their ancestors were Native or not. Examples of this include participants, both Native and non-Native American who worked on traditional crafts. Kakwa tsiltsil, a non-Native participant was very active in the other culture classes offered through the CTGR tribal offices. He learned to make a traditional button shawl 
and baskets through the classes. Other participants also made traditional baskets or carvings. Some participants brought materials collected by linguists, for example, field notes or traditional Native myths translated to English. Over the course of my three years involvement, some participants brought in books about Oregon history.

Participants cited their self-ascribed identities as reasons for their involvement in Chinuk Wawa. One source of evidence was the observations I made of the participants while they were in class, as discussed in the following section.

\section{Supporting evidence from participant-observation.}

Objects participants brought to Chinuk Wawa classes were connected to their identities. Kakwa tsiltsil spoke about being oriented to plant energy and was interested in working with camas root. He often brought native plants, berries and roots to class to share with other students and teachers. He brought thimbleberries when they ripened in August. He brought locally harvested camas root that he cooked for 24 hours in his oven for us to sample. He brought dried native blackberries. He brought Wapato, another starchy root that was a staple of the traditional diet whose survival is now threatened by habitat loss. The two linguists often brought their computers with digital and paper archives of Chinuk Wawa. One of the linguists often brought a high-quality digital audio recorder which he would use to record conversations in Chinuk Wawa. The teachers brought their teaching supplies. The teacher for the LCC distance-learning class brought handouts, and the community teacher brought teaching tools like cards, samples of native plants, and food for students and whoever showed up. One Native participant often brought stories and archives of material written in her tribal 
language. She would talk extensively with one of the linguists about these papers. These objects served to corroborate data about participants' identities as motivation to learn Chinuk Wawa.

\section{Guiding question 3.}

3. What does Chinuk Wawa represent to the Portland Chinuk Wawa language community?

For this community, Chinuk Wawa is much more than a code of communication to the participants. Chinuk Wawa is a link to the past and to an idealized future. Chinuk Wawa is the common link between a group of people who care about each other and feel some sense of community with each other.

Chinuk Wawa, as a hybrid between Pacific Northwest indigenous languages and the colonial languages, English and French, represented multiple things to participants. Some participants oriented to the indigenous aspects of the language. Others found entrance into the community and legitimacy in participation in the fact that Chinuk Wawa was a trade language historically spoken by Native people as well as explorers, traders, pioneers, and settlers. Participants' orientations differed in part based on their personal and professional identities.

Chinuk Wawa represented an all-inclusive, welcoming language with different historical baggage than English. Kanim spoke about how its history as a trade language made it the perfect language to be spoken again by people living here. To her, it represented a language through which people currently living in the Pacific Northwest could connect more deeply to this place. 
The theme of Connection highlighted many of the symbolic meanings participants attributed to Chinuk Wawa: as connected to ancestors, as encoding another worldview, and as a portal to history of the Pacific Northwest.

In Chapter Four, Kanim discussed the lack of an entity with the ultimate authority to give or revoke permission about where and how to use Chinuk Wawa. This dilemma was reflected in conversations I had with other students and teachers. A Chinuk Wawa language community allows for a place where it is possible to connect to the past and to valuable things that have been lost or gone dormant from mainstream culture. It is also a place to face the facts about the history, hegemony, and exploitation that occurred in this region between the colonizers and the colonized. It is a place to acknowledge many events and experiences that have been swept under the rug in our cultural memory, our cultural conscience, and our cultural story. Through involvement in the Chinuk Wawa language community, participants, both Native and non-Native, embodied an effort to change that hegemonic relationship by relating to each other with consideration and support.

\section{Status within the Community}

This analysis is based on my experience within the community and includes the community outside of the participants. Though it fell outside of the scope of my study, I decided to include it as it may be helpful to future language planning and future classes.

The term "community" is defined as the people who attend Chinuk Wawa classes on Wednesday nights at the Confederated Tribes of Grand Ronde (CTGR) 
Portland tribal office. This community was a contact zone, as presented by Pratt (1996), where Native and non-Native American people from different groups (linguists, language aficionados, plant- and earth-oriented people), came together because of this hybrid language, Chinuk Wawa. There were people from different parts of American society in terms of level of education, socioeconomic class, and ethnicity.Status within the community depended on social ties, ethnic background, and professional status. Linguists studied, taught, and documented the language in an academic manner. Other people learned Chinuk Wawa through the 'Where are your Keys' Method (see pp. 17-18) and were interested in learning and strengthening the language for largely personal reasons often with respect to deepening their relationships with the earth. And lastly, there were Native people, both CTGR tribal members and members of other Pacific Northwest tribes. The CTGR Native people seemed to be considered the most legitimate members of this group. The Pacific Northwest Native people seemed to be the next most legitimate. The linguistically-oriented, non-Native people were next in line of legitimacy with the other, non-Native, non-linguistic oriented people most peripheral. This legitimacy hierarchy functioned as a way for students and other members to know who to approach with questions about the language or appropriate use of the language.

CTGR tribal member <-- PNW Native<--Native <-- Linguist<--non-Native, non-linguist

There were some caveats however. Relationships, loyalty, consistency of commitment, personality, and efforts to preserve Chinuk Wawa strongly contributed to 
a more legitimate membership. If people came to class consistently over several months, they were more accepted into the community by teachers and other committed students. This acceptance was shown by longer conversations, invitations to meet outside of class or to go to other events, and the sharing of resources about Chinuk Wawa linguistics, language teaching, Native American traditional crafts, or Pacific Northwest plants. Those who made efforts to create language classes, teach classes, and create curriculum in appropriate ways, through their own initiative or jointly (often a non-Native with a Native member), were more accepted and appreciated by the more established members.

\section{Limitations of Study}

This study was designed as a qualitative, exploratory, ethnographic case study situated within the social constructivist paradigm. Factors considered as limiting are the number of participants, how my relationships to the community members made it difficult to gain perspective for writing the description and analysis, and the length of time the study took.

This study is limited by its design to interviews with only a small number of people from one language program at one site. There were many more people than were interviewed involved in learning and teaching Chinuk Wawa in the Portland, Eugene, and Grand Ronde communities. Including more people in the study would likely have shown an even more nuanced and complex picture than presented here.

At this time of my interviews, I had been participating in this language community for over three years. My experiences in the community affected the 
interviews and descriptions of the participants (see Role of the Researcher section, Chapter Three). Additionally, because of my involvement, it was challenging to dissociate from the community enough to analyze it. While writing the description and analysis, I struggled to get a bird's eye view of the community. In order to deal with this difficulty, after the data collection period, I refrained from going to classes for a month or so and then attended classes less frequently.

The length of time this study took was a frustration and a limitation because many changes occurred within the community over the course of my involvement and research. Had I been able to complete the study in a shorter period of time, I may have been able to provide a more concise and deeper analysis of participants' motivations. As it stands, a few participants' motivations shifted significantly over the period of this study and may have shifted significantly since I interviewed them last year from March to May 2011. Some of the motivations expressed by participants may now be irrelevant. However, through being a part of the community for over three years, I was able to observe significant shifts and see the dynamic, changing nature of motivation within individuals and within a community, an important finding in and of itself.

\section{Implications}

This study may support decisions for community outreach as well as provide the groundwork for future research.

\section{Suggestions for community outreach.}

One important demographic that I observed in the Chinuk Wawa language community were the linguistic students from Portland State University (PSU). Some of 
these students became long-time members and contributors to the Chinuk Wawa revitalization effort. Therefore, this population seemed to be one that could be fruitful for future focus. Already, linguists from the Portland Chinuk Wawa language community make presentations to classes of linguistic students at PSU about Chinuk Wawa.

If linguists, tribal members and others within the Portland Chinuk Wawa community created manageable and useful projects, they could attract additional linguistic students to learn about language revitalization as well as contribute to preserving Chinuk Wawa. A tighter collaboration between the Grand Ronde and Portland Chinuk Wawa language communities would be ideal in order to identify and develop project ideas for Portland State University students.

As a few participants mentioned in the interviews, any community effort depends on the strength of people's commitments to the cause as well as to each other. Within the Portland community, as well as the Grand Ronde and Eugene community, many such relationships and commitments already exist. For example, the Lane Community College classes represent collaboration between Lane Community College; the Northwest Indian Language Institute; the Confederated Tribes of Grand Ronde; and the Chinuk Wawa language communities in Grand Ronde, Eugene and Portland. A community-visioning process could serve to strengthen these motivating personal relationships within this community and create a more cohesive vision for the future. With strong leadership from CTGR, there would be great potential for expanding and 
strengthening the Chinuk Wawa revitalization effort through collaboration and effective organization.

\section{Future research.}

Rigorous research on Chinuk Wawa is valuable in that it can raise awareness about this language in the wider regional population. A future study could build upon this current research by using and/or adapting its tools (interview questions, methodological design) and applying them to a larger group. This would be a useful way to further characterize this community and assess its needs. Additionally, this same study could be used to study populations of interest, for example CTGR tribal members. As the target population for Chinuk Wawa revitalization, at least in the context of this study, understanding their motivations or lack of motivations would help to improve the program as well as provide research for the academic and language revitalization communities. Finally, a study focused primarily on program evaluation of the Portland Chinuk Wawa language classes could serve to identify the specific needs of the classes.

This study focused on motivations for participants' involvement. In the field of second language research, motivation is usually studied as it relates to achievement in a second language. Researching students' motivations as related to their achievement in acquiring Chinuk Wawa would be useful in order to further hone curriculum and increase student success.

The results of this study will be useful to other language revitalization programs by providing specific information about what motivates people to learn and teach 
endangered languages. Understanding the motivations of these learners and teachers can help language program designers to tailor their curriculum, teaching styles, and methods more effectively as well as allowing programs to target their outreach efforts to specific communities.

This study invites deeper reflection into the factors that engage people to learn an endangered language like Chinuk Wawa. Language revitalization is a challenging undertaking because it requires many people to be invested on many levels. The clearer the vision and motivation of the people involved, the more likely the endeavor will succeed.

\section{Conclusion}

Participants' main motivations to begin and continue study of Chinuk Wawa were the connections participants made through the language to Native and nonNative PNW history and to the region. Additionally, the Chinuk Wawa language served as a nexus for people of multiple identities to express and strengthen their identities.

This Chinuk Wawa language community created a unique space where inquiry, networking, and sharing of different types of values took place. I trust it can continue in the face of the formidable challenges of low-funding and the small number of regular participants. Recently, there have been some bright developments. The CTGR Chinuk Wawa dictionary has been successfully published, allowing for wide public access to this language as historically spoken by the CTGR people and used in myths and stories. Additionally, a Chinuk Wawa class, started in September 2011 and held at Portland State University, is meeting twice a week with strong attendance. 
During what now amounts to four years of involvement with the Chinuk Wawa language revitalization effort, I have seen an amazing number of changes and developments, guided by the efforts of many different organizations and individuals. And it is my sincere hope that these entities continue to navigate through the challenges in order to successfully revitalize Chinuk Wawa.

The Chinuk Wawa language serves a valuable role in helping modern Oregonians, Native and otherwise, to connect to the roots and history of this beautiful place, giving us the tools to care for it on behalf of present and future generations. 


\section{REFERENCES}

American Council on the Teaching of Foreign Languages. ACTFL Proficiency Guidelines 2012 [PDF]. (2012). Retrieved from http://www.actfl.org/files/public/ACTFLProficiencyGuidelines2012_FIN AL.pdf

Boas, F. (1892). The Chinook Jargon. Science, 19, 129.

Bucholtz, M., \& Hall, K. (2005). Identity and interaction: A sociocultural linguistic approach. Discourse Studies, 7, 585-614. DOI: $10.1177 / 1461445605054407$

Bucuras, S. D. (2004). Language change and ethnic identity in the Portland, Oregon Romanian-American community. (Unpublished master's thesis). Portland State University, Portland, OR.

Bunte, P. A. (2009). Language socialization and Paiute identity. In P. V. Kroskrity \& M. C. Field (Eds.), Native American language ideologies (pp. 172-189). Tuscon: The University of Arizona Press.

Colbert, M. (1942). Kutkos Chinook tyee. D.C. Heath \& Company: Boston.

Confederated Tribes of Grand Ronde. (n.d.). Ntsayka Ikanum (Our Story). Retreived from http://www.grandronde.org/ikanum/index.html

Confederated Tribes of Grand Ronde. (2011). Chinuk Wawa: As our elders teach us to speak it. Seattle: University of Washington Press.

Cresswell, J. W. (2007). Qualitative inquiry and research design: Choosing among five approaches. London: Sage Publications.

Cummins, J. (2005). A proposal for action: Strategies for recognizing heritage language competence as a learning resource within the mainstream classroom. The Modern Language Journal, 89, 585-592.

Davis, G. M. (1998). 'Indian Country-Indian Language': A participant observation case study of language planning by the Confederated Tribes of the Grand Ronde community of Oregon. (Unpublished master's thesis). Portland State University, Portland, OR.

Dörnyei, Z. (2005). The psychology of the language learner: Individual differences in second language acquisition. New York: Lawrence Erlbaum Associates. 
Dörnyei, Z. (2009). The L2 motivational self system. In Z. Dörnyei \& E. Ushioda (Eds.), Motivation, language identity, and the L2 self (pp. 9-42). Toronto: Multilingual Matters.

Ellis, R. (2008). The study of second language acquisition (2nd ed.). Oxford: Oxford University Press.

Fishman, J. (2002). What do you lose when you lose your language? In G. Cantoni (Ed.), Stabilizing Indigenous Languages (pp. 80-91). Flagstaff: Northern Arizona University.

Gardner, R. C. \& Lambert W. E. (1972). Attitudes and motivation in second-language learning. Massachussetts: Newbury House Publishers.

Gass, S. M., \& Selinker, L. (2001). Second language acquisition: An introductory course. Mahwah, New Jersey: Lawrence Erlbaum Associates, Publishers.

Gibbs, G. (1863). A dictionary of the Chinook Jargon, or trade language of Oregon. New York: Cramoisy Press.

Gill, J. K. (1909). Gill's dictionary of the Chinook Jargon. Portland, OR: The J.K. Gill Company.

Grenoble, L. A., \& Whaley, L. J. (2006) Saving languages: An introduction to language revitalization. Cambridge: Cambridge University Press.

Greymorning, S. (1999). Running the gauntlet of an indigenous language program. In J. Reyhner, G. Cantoni, R. N. St. Clair, \& E. P. Yazzie (Eds.), Revitalizing indigenous languages (pp. 6-16). Flagstaff, AR: Northern Arizona University.

Gomez de Garcia, J., Axelrod, M., \& Lachler, J. (2009). English is the dead language: Native perspectives on bilingualism. In P. V. Kroskrity \& M. C. Field (Eds.), Native American language ideologies (pp. 99-122). Tuscon: The University of Arizona Press.

Hamada, Y. (2011). Different demotivators for Japanese junior high and high school learners. Journal of Pan-Pacific Association of Applied Linguistics, 15, 1, 15-38.

Hale, H. (1890). An international idiom: A manual of the Oregon trade language, or "Chinook Jargon." London: Whittaker \& Co. 
Hale, K., Krauss, M., Watahomigie, L. J., Yamamoto, A. Y., Craig, C., Jeanne, L. M., et al. (1992). Endangered languages. Language, 68, 1-42.

Haynes, E. F. (2004). Obstacles facing tribal language programs in Warm Springs, Klamath, and Grand Ronde. Coyote Papers, XIII, 87-102.

Haynes, E. F. (2007). The present climate for Native language education. In J. Gross (Ed.), Teaching Oregon Native languages (pp. 69-93). Corvallis: Oregon State University Press.

Hinton, L. (1996). Flutes of fire: Essays on Californian Indian languages. Berkeley, CA: Heyday Books.

Kroskrity, P. V., \& Field, M. C. (2009). Native American language ideologies. Tucson: University of Arizona Press.

Lang, G. (2008). Making wawa: The genesis of Chinook Jargon. Vancouver, B.C.: UBC Press.

Larsen-Freeman, D., \& Long, M. H. (1991). An introduction to second language acquisition research. London: Longman.

Littlebear, R. (1999). Some rare and radical ideas for keeping indigenous languages alive. In J. Reyhner, G. Cantoni, R. N. St. Clair, \& E. P. Yazzie (Eds.), Revitalizing indigenous languages (pp. 1-5). Flagstaff, AR: Northern Arizona University.

Lincoln, Y. S., \& Guba, E. G. (1985). Naturalistic inquiry. London: Sage Publications.

McCarty, T., Romero, M.E., \& Zepeda, O. (2006). Reclaiming the gift: Indigenous youth counter-narratives on Native language loss and revitalization. American Indian Quarterly, 30 (1,2), 28-48.

Meek, B. A. (2009). Language revitalization in the Yukon. In P. V. Kroskrity \& M. C. Field (Eds.), Native American language ideologies (pp. 151-171). Tuscon: The University of Arizona Press.

Norton, B. (2000). Identity and language learning: Gender, ethnicity and educational change. New York : Longman.

Norton Pierce, B. (1995). Social identity, investment, and language learning. TESOL Quarterly, 29, 9-31. 
Pratt, M. L. (1996). Arts of the contact zone. In D. Bartholomae and A. Petrosky (Eds.). Resources for teaching ways of reading: An anthology for writers (pp. 440-460). Boston: Bedford books.

Reyhner, J., \& House, D. (2002). In G. Cantoni (Ed.), Stabilizing indigenous languages (pp. 133-142). Flagstaff: Northern Arizona University.

Sebba, M. (1997). Contact languages: Pidgins and creoles. New York: St. Martin's Press.

Segalowitz, N., Gatbonton, E., \& Trofimovich, P. (2009). Links between ethnolinguistic affiliation, self-related motivation and second language fluency:

Are they mediated by psycholinguistic variables? In Z. Dörnyei \& E. Ushioda (Eds.), Motivation, language identity, and the L2 self (pp. 164-192). Buffalo: Multilingual Matters.

Shaw, G. C. (1909). The Chinook jargon and how to use it. Seattle, WA: Rainier Printing Company. Retrieved from http://books.google.com/books?id=8bUUAAAAYAAJ\&ots=eBhXMLfQ7\&dq=Shaw\%20Chinook\%20Jargon\&pg=PR5\#v=onepage\&q=\&f=false

Sieberg, M. O. (2002). Language maintenance and ethnic identity in the Portland Estonian-American community. (Unpublished master's thesis). Portland State University, Portland, OR.

Siedman, I. E. (1991). Interviewing as qualitative research. New York: Teacher's College Press.

Silverstein, M. (1996). Encountering language and languages of encounter in North American ethnohistory. Journal of Linguistic Anthropology, 6, 2, 126144.

Spielmann, G., \& Radnofsky, M. L. (2001). Learning language under tension: New directions from a qualitative study. The Modern Language Journal, 85, 259278.

Stake, R. E. (1995). The art of case study research. London: Sage Publications.

Thomas, E. H. (1970). Chinook: A history and dictionary of the Northwest Coast trade jargon. ( $2^{\text {nd }}$ ed.). Portland, OR: Binfords \& Mort. 
Triantafillidou, L., \& Hedgcock, J. S. (2007). Learning Modern Greek: A comparison of development and identification patterns among heritage and foreign language learners. Journal of Language, Identity, and Education, 6, 1-30.

Twenge-Jinings, F. (2006). Assessing Chinuk Wawa immersion preschool gains in the community of the Confederated Tribes of Grand Ronde. (Unpublished master's thesis). Portland State University, Portland, OR.

Ushioda, E. (2011). Why autonomy? Insights from motivation theory and research. Innovation in Language Learning and Teaching, 5(2), 221-232.

Watahomigie, L. J. (1998). The Native language is a gift: A Hualapai language autobiography. International Journal of the Sociology of Language, 132: 5-7.

Williams, M. (1994). Motivation in foreign and second language learning: An interactive perspective. Educational and Child Psychology, 11(2), 77-84.

Williams, M., \& Burden, R. (1997). Psychology for language teachers: A social constructivist approach. Cambridge University Press: Cambridge.

Zenk, H. B. (1984). Chinook Jargon and Native cultural persistence in the Grand Ronde Indian community, 1856-1907: A special case of creolization. Unpublished Doctoral Dissertation, University of Oregon.

Zenk, H. B. (1988). Chinook Jargon in the speech economy of Grand Ronde Reservation, Oregon: An ethnography-of-speaking approach to an historical case of creolization in process. International Journal of the Sociology of Language, 71, 107-124. 


\section{APPENDIX A: SAMPLE/TYPICAL INTERVIEW QUESTIONS}

$1^{\text {st }}$ Section: General questions about learning Chinuk Wawa (warm-up, allow participant to make meaning from their experience without leading questions.) How did you find out about the Chinuk Wawa classes?

How long have you been coming to the classes? Which classes (community, distance learning, NAYA community class, writing group)?

Tell me about learning Chinuk Wawa? What has learning Chinuk Wawa been like for you?

$2^{\text {nd }}$ Section: Taking Chinuk Wawa classes (motivation)

Why did you want to learn or teach Chinuk Wawa?

Why did you start? What keeps you coming back?

$3^{\text {rd }}$ Section: Use of Chinuk Wawa and Networks (links to social identity)

Do you use Chinuk Wawa outside of class?

Can you describe a situation where you spoke Chinuk Wawa outside of class?

- Who were you talking with?

- What did you talk about?

- Why do you use it? (instead of another language, like English?)

Do your family members know that you are studying Chinuk Wawa?

- What do they say about it?

- What is their response?

Have you been to any ceremonies or events where Chinuk Wawa was being used?

$4^{\text {th }}$ Section: Learning Chinuk Wawa (second language learner identity, language as symbolic, what part do languages play in participant's life?)

Have you studied or taught other languages? Which ones?

Do you think learning/teaching Chinuk Wawa is different from learning/teaching other languages? How? Why or why not?

Do you think anything has changed in your life since you began learning/teaching Chinuk Wawa? (Priorities? Interests?)

$5^{\text {th }}$ Section: Views of Chinuk Wawa as a unique language (Limitations, differences from learning/speaking other languages)

Are there things you want to talk about or do in Chinuk Wawa, but can't? What makes it difficult or impossible?

How do you feel about these limitations? 
Who would you want to talk with if there weren't limitations on the language or your ability to speak it? Where? Why?

Do you think/feel that there are any differences when you read stories in Chinuk Wawa versus stories in English or other languages? How? Why?

\section{$6^{\text {th }}$ Section: Questions based on ethnic identity}

Questions for self-identified Native participants

What kind of community did you grow up in? A tribal community?

Do you think you were influenced by your tribe or community growing up? If so, in what ways?

Did you hear any Native languages spoken in your tribe or community growing up? If so, which languages? How much were these Native languages spoken and by whom? Do you know if your grandparents or relatives spoke Chinuk Wawa? If so, in what context? How much?

If so, how do you feel about speaking one of the languages spoken by your grandparents/elders/older people in your community?

Have you ever heard of any opinions about non-Natives speaking this version of the Chinuk Wawa (which is based on elder Native speakers mostly from the GR reservation)?

Does Chinuk Wawa relate to your religious and/or spiritual beliefs? How so?

Do you see links between studying Chinuk Wawa and your religious or spiritual practices?

Questions for self-identified, non-Native participants

What kind of community did you grow up in?

Do you think there are links to you deciding to learn Chinuk Wawa and your childhood community?

Do you think you were influenced by your community growing up? If so, in what ways?

Did you hear any languages other than English spoken in your community growing up? If so, which languages? How much were these languages spoken and by whom? Do you know if your grandparents or relatives spoke languages other than English? If so, in what context? How much?

How do you feel about speaking a language spoken by Native and non-Native people in this region?

How do you feel about speaking this language as a self-identified non-Native person? Does Chinuk Wawa relate to your religious and/or spiritual beliefs? How so? 
Do you see links between studying Chinuk Wawa and your religious or spiritual practices?

\section{$7^{\text {th }}$ Section: Questions for teachers}

Which classes have you taught? (ages, levels, context/institution)

Tell me about teaching Chinuk Wawa?

What has it been like for you?

Why do you continue teaching this language?

As a teacher, what challenges do you face?

As a teacher, what is rewarding to you?

What is your vision for this language and its community of speakers?

\section{$8^{\text {th }}$ Section: Summative Questions}

Has your motivation changed or shifted since you started studying Chinuk Wawa?

What does the language mean to you?

What is your vision for this language and its community of speakers?

Potential Questions/Activities

BRAINSTORMING

On a piece of paper, write down words, bits of sentences, thoughts that come into your mind when you hear the phrase "Chinuk Wawa" (Adapted from Bucaras, 2003, p. 168). 


\section{APPENDIX B: QUESTIONNAIRE}

Pseudonym Choice (stapled to back of questionnaire)

Real Participant Name:

Pseudonym (chosen by participant):

Questionnaire

1. Date:

2. Pseudonym:

3. City of Residence:

4. City/State/Country of birth:

5. Age:________-_-_ Gender:

6. How do you describe your ethnicity?:

7. What is/are your first language(s)?

8. What other languages besides Chinuk Wawa have you learned?:

a. Language Learned \#1 (if applicable):

1. How long did you study it? When?

2. In what context? (Where?):

3. Why did you study this language?

4. Estimate of your fluency (beginner, intermediate,

*Beginner - You can say memorized phrases and know some basic vocabulary of common objects.

Intermediate - You can ask and answer simple questions on familiar topics, and handle a simple situation or transaction.

Advanced - You can narrate and describe in past, present, and future time/aspect, and handle a complicated situation and transaction.

b. Language Learned \#2 (if applicable):

1. How long did you study it? When?

2. In what context? (Where?):

3. Why did you study this language?

4. Estimate of your fluency (beginner, intermediate, advanced)?: 
Questionnaire, continued

c. Language Learned \#3 (if applicable):

1. How long did you study it? When?

2. In what context? (Where?):

3. Why did you study this language?

4. Estimate of your fluency (beginner, intermediate, advanced)?:

Follow-up interview:

By checking this box, I agree that I am willing to participate in a follow-up interview and talk about my responses from the first interview. The second interview would be audio-recorded also and included in the final write-up of the study.

Degree of Consent: Check which statements you consent to and sign below them:

I agree that everything I say can be used in the final manuscript of this study, including excerpts of audiotapes, while maintaining my anonymity;

Signature Date

I agree that the researcher may use my statements and recorded voice in future publications or conference presentations while maintaining my anonymity.

Signature

Date

The researcher must show me what quotes or paraphrased perspectives she plans to include in the final manuscript of this study from our interview, and I must give my written approval, shown by signing the list of quotes she would like to include in her write-up.

Signature

Date 


\section{APPENDIX C: PRELIMINARY THEMES FROM PILOT STUDY}

Thematic analysis - Preliminary Schema

Guiding Questions: What motivates people to study Chinuk Wawa? What part does identity play in that motivation? What does Chinuk Wawa represent to its speakers?

Place

1) PLACE (link to culture, history): a link to the indigenous cultures of the Northwest

2) PLACE (ecology, environmentalism): a way to connect to the land, local ecology, create a stronger sense of place

Linguistic Orientation

3) UNIQUE LEARNING OPPORTUNITY - learning Chinuk Wawa as a unique and distinct kind of opportunity

4) COMMUNICATION (Canoe Journeys): a way to communicate in certain domains (canoe journey)

5) EXOTIC SOUNDS (language as new, different)

6) SPECIFIC LINGUISTIC ITEMS

Identity

7) IDENTITY (reinforcing): sense of one's self, a strengthening of an already present identity (ethnicity, link to place)

8) ETHNIC: a link to ancestors, history

9) FAMILY and FRIENDS: how are family members involved? supportive/invested vs. supportive/not invested

10) NETWORKS: COMMUNITY/WORK/ACADEMIC

Language Ideology

11) VALUES: language revitalization

12) PERSONAL BELIEFS (about language, ideologies)

Cultural Orientation

13) CULTURAL (spirituality): language as the vehicle for spirituality. ...

14) CULTURAL (tribal values): reconnection to core tribal values

15) CULTURAL (similarity/difference)

16) CULTURAL (traditions) 
Orientation to Language Learning

17) ATTITUDES

a. FUN

18) ENVIRONMENT/CULTURE OF LEARNING

19) LEARNING and TEACHING STRATEGIES

Challenges/obstacles/reasons for not taking Chinuk Wawa

20) SCHEDULING CONFLICTS

21) UNMOTIVATING FACTORS 